DEPARTMENT OF THE INTERIOR

UNITED STATES GEOLOGICAL SURVEY

GEORGE OTIS SMITH, DIRECTOR

BULIETIN 590

RECONNAISSANCE

A N W ELLD

OF THE

\title{
GEOLOGY AND OIL PROSPECTS OF NORTHWESTERN OREGON
}

\author{
BY \\ CHESTER W. WASHBURNE
}

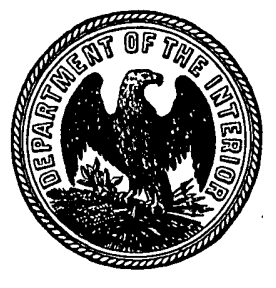

WASHINGTON

GOVERNMENT PRINTING OFFIOE 



\section{CONTENTS.}

Page.

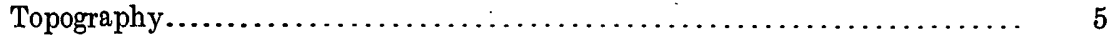

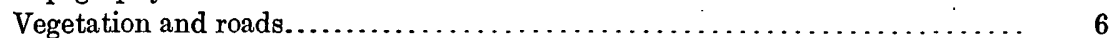

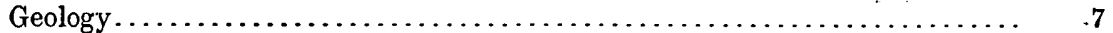

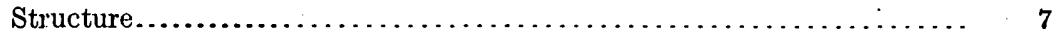

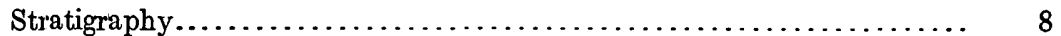

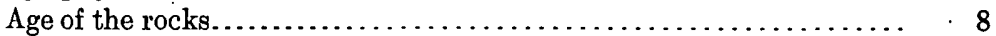

Tertiary system................................... 8

Eocene series............................... 8

Oligocene series.................................. 13

Occurrence and character.......................... 13

Astoria shale (Oligocene and Miocene).............. 15

Miocene series................................... $\quad 20$

Occurrence and character........................ $\quad 20$

Lower division of the Miocene........................ 21

Upper division of the Miocene....................... 23

Pliocene series................................ 27

Paleontologic data............................................. 27

Marine fossils ..................................... 27

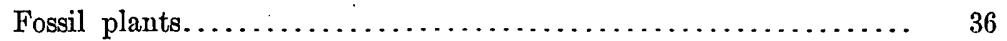

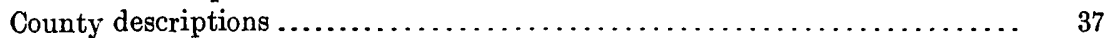

Clatsop County............................................. 37

Geology........................................ 37

General features................................. $\quad 37$

Columbia River region.............................. $\quad 37$

Youngs River basin............................... 44

Nehalem River basin.............................. 46

Southwestern Clatsop County....................... 49

Northwestern Clatsop County....................... 51.

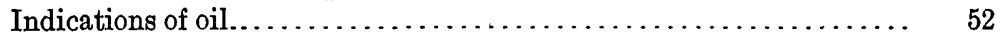

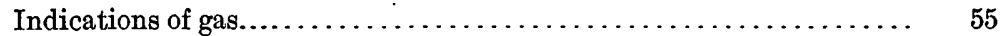

Sources...................................... 55

Marsh gas........................................... 56

Gas in Tertiary strata ............................... 58

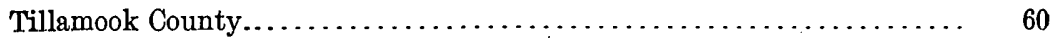

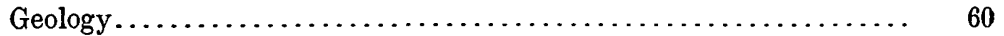

Nehalem and Wilson River basins .................... $\quad 60$

Tillamook River basin............................... 63

Nestugga River basin............................. 64

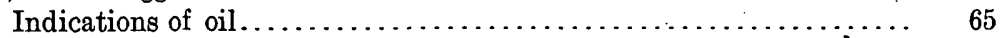

Nehalem beeswax ................................ $\quad 65$

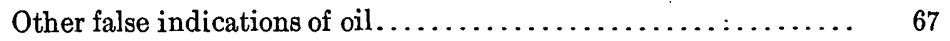

Asphaltum ......................................... 67

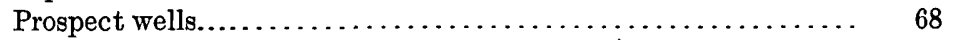

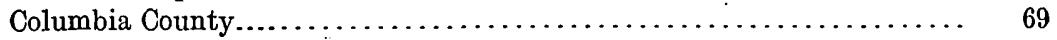

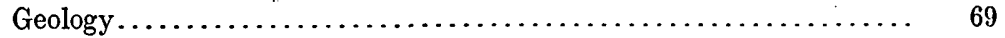

Northeastern Columbia County ..................... $\quad 69$

Nehalem River basin............................. $\quad 70$

Northwestern Columbia County .................... 74

Indications of oil ...................................... 75 
County descriptions-Continued.

Page.

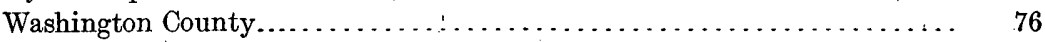

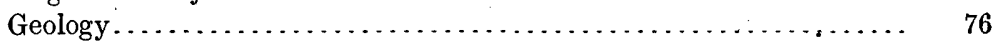

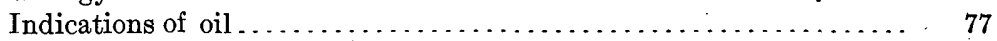

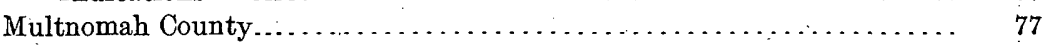

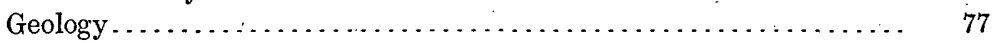

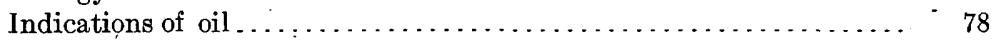

Clackamas County .................................. 78

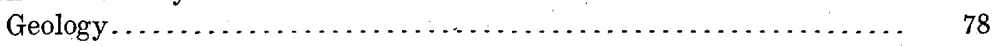

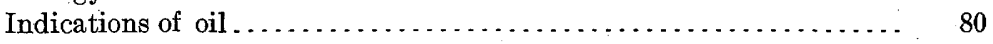

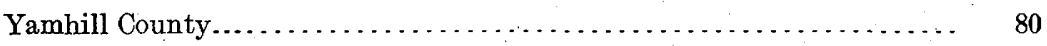

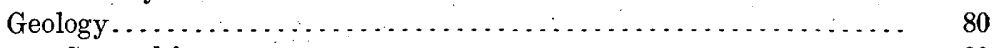

General features................................... 80

Northeastern Yamhill County $\ldots \ldots \ldots \ldots \ldots \ldots \ldots \ldots \ldots \ldots . . \quad 80$

Southern Yamhill County ......................... 83

Structure.................................... 86

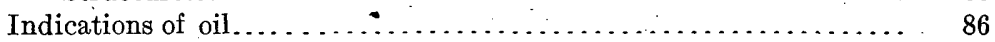

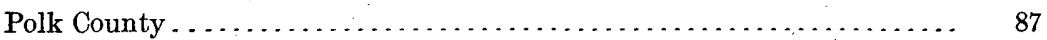

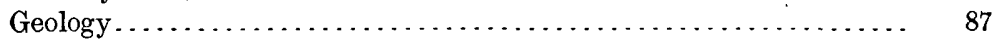

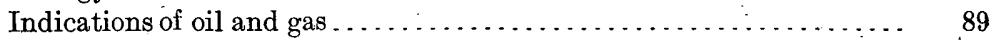

Marion County........................................ 90

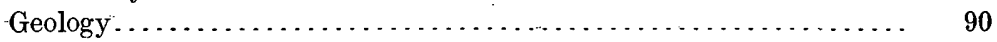

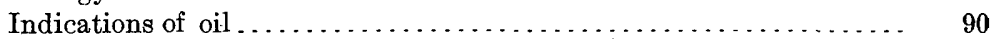

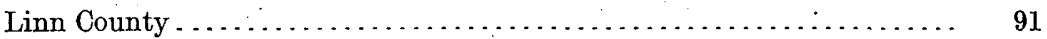

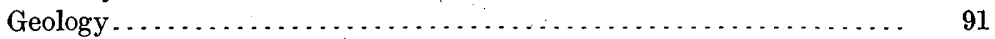

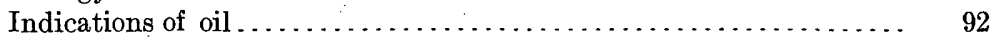

Benton County .............................................. 92

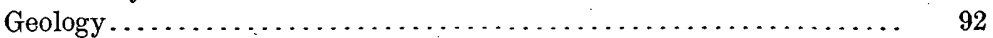

Indications of oil . . . . . . .

Lincoln County....................................... 95

Geology ......................................... 95

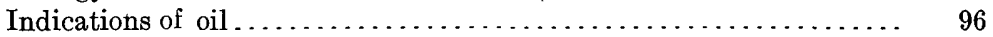

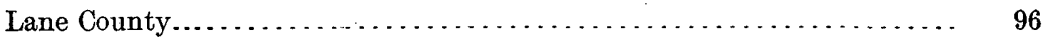

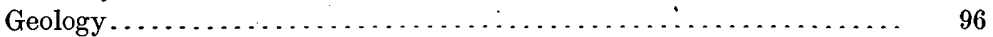

General features................................... 96

Western Lane County .............................. $\quad 96$

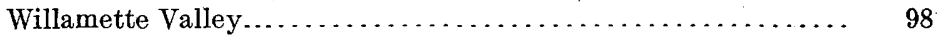

Indications of oil ................................... 100

Douglas County . . . . . . . . . . . . . . . . . . . . . . . . . . . 102

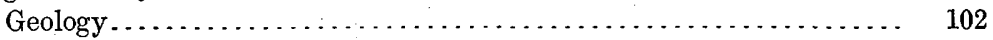

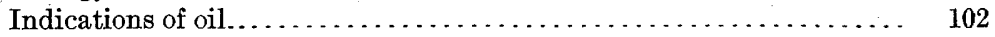

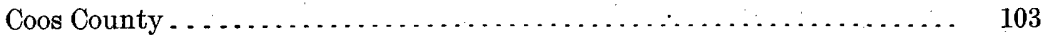

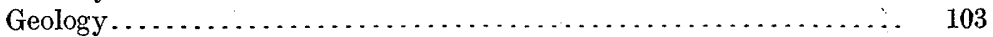

Indications of oil and gas. $\ldots \ldots \ldots \ldots \ldots \ldots \ldots \ldots \ldots \ldots \ldots \ldots, 103$

Conclusions.............................................. 105

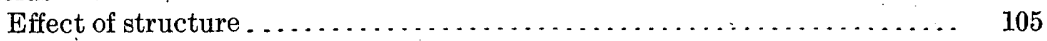

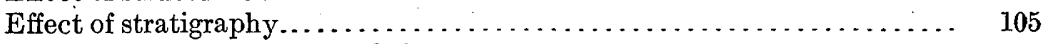

Significance of indications of $0 i 1 . \ldots \ldots \ldots \ldots \ldots \ldots \ldots \ldots \ldots \ldots, 106$

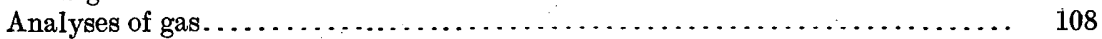

\section{ILLUSTRATION.}

Plate I. Map of northwestern Oregon, showing gas and oil prospects. 


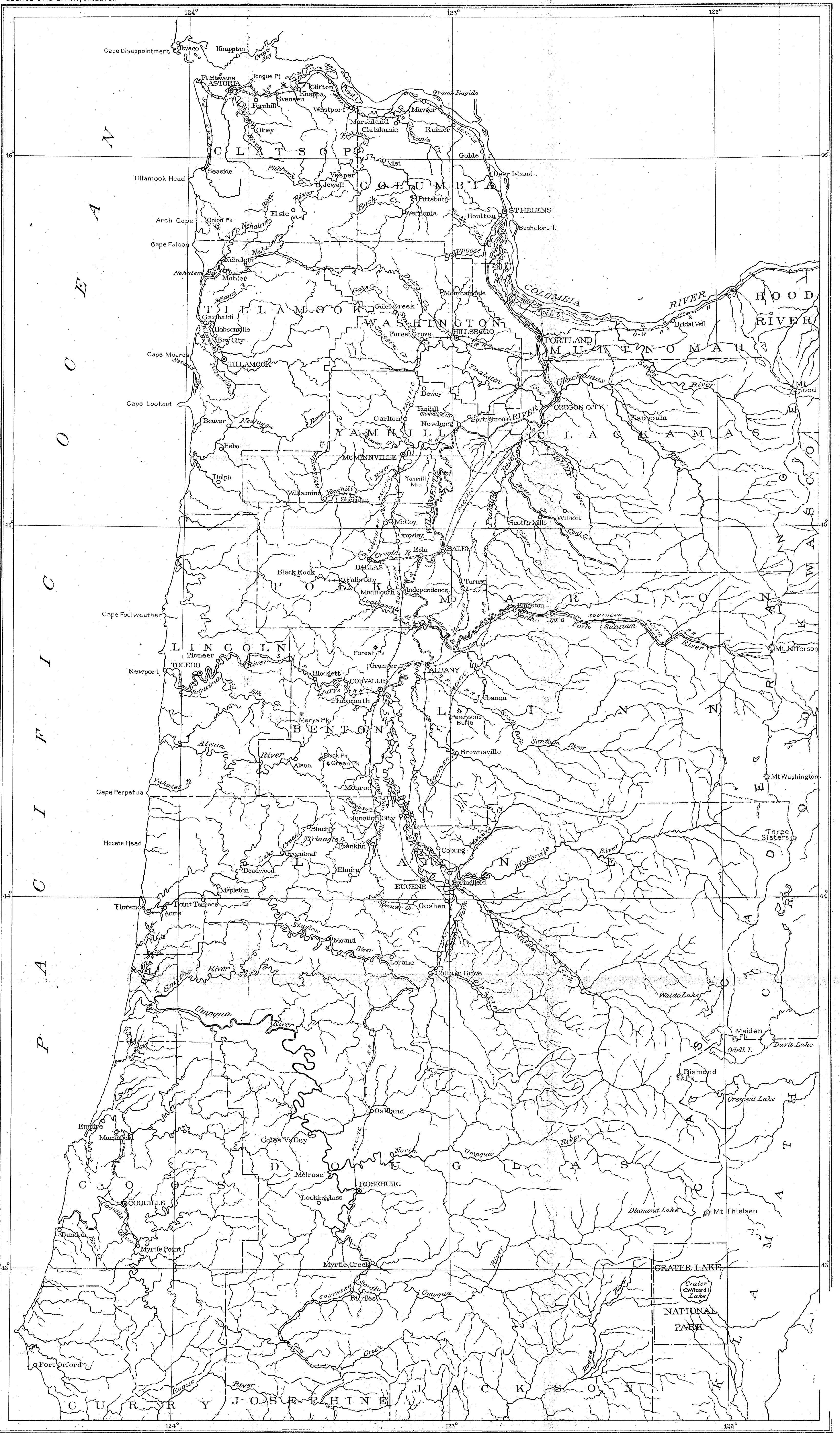




\section{RECONNAISSANCE OF THE GEOLOGY AND OIL PROSPECTS OF NORTHWESTERN OREGON.}

By Chester W. Washburne.

INTRODUCTION.

The presence of oil in the Coast Range of Oregon has been suggested by the topographic similarity of the locality to the oil regions of California, most of which are in the borders of the Coast Range. A few attempts to obtain oil have been made, eight wells having been drilled in northwestern Oregon, all of which are dry, but one of which, near Dallas, yielded a small flow of gas. All these wells, however, were located without adequate regard to the geologic conditions of the localities and therefore do not afford a fair test of the ground.

This report is based on a hasty reconnaissance made during the summer of 1910 and on several explorations made by the writer in the years 1900 to 1905 . In the summer of 1910 material assistance in the field was rendered by Mr. George A. Macready and Mr. Reese F. Rogers, who examined many supposed oil seeps and other reported indications and gathered notes on the geology of the region. In March, 1914, some new reports of oil seeps were investigated, but nothing was found to change the generally negative conclusion of the earlier work.

The evidence gathered in the field seems to indicate that the prospect of obtaining oil in the northern part of the Coast Range near Astoria or Tillamook is slight, but that the chances are much better in the central part of the Coast Range in western Coos, Douglas, and Lane counties or in Lincoln County. It should be borne in mind, however, that this is merely a statement of the writer's personal opinion, based on imperfect evidence, and not a prediction that oil will be found in commercial quantities.

The region covered and the oil prospects are shown on the accompanying map (Pl. I).

\section{TOPOGRAPHY.}

The principal topographic feature of the region is the Coast Range, an irregular group of maturely dissected hills that rise gradually from altitudes of only a few hundred feet near the sea to heights of 
1,000 to 2,500 feet. The main divide, or watershed, is irregular, running approximately parallel with the coast at a distance of 25 to 35 miles from the sea and 10 to 20 miles from the eastern foot of the range. The main divide does not everywhere correspond with the line of highest summits, but in many places lies east or west of them.

The anomalous course of Nehalem River through the range appears to be due to the peculiar distribution of resistant igneous rocks rather than to capture. Some sections of the summit likewise owe their superior altitude to the presence of resistant intrusives. The bold headlands, typified by Tillamook Head, which stand conspicuously above the neighboring hills and extend their high terminal cliffs well into the sea, owe their existence to the hard basalt composing them. Likewise, the higher mountains of the Coast Range, such as Saddle, Necarney, Onion, Marys, and Roman Nose, are all due to the presence of intrusive dolerite, diorite, and diabase.

\section{VEGETATION AND ROADS.}

Geologic work in the Coast Range of Oregon and Washington is done under unusual difficulties, owing to the scarcity of exposures and to the almost impenetrable growth of bushes and ferns. The brush is especially dense along creeks and in old "burns," but it is troublesome everywhere, even in the perpetual shade of the great evergreen forest that covers most of the region. The humid climate of western Oregon has thoroughly decomposed all but the hardest rocks to depths of 20 to 100 feet, unaltered rocks being seen only in artificial excavations or in small cliffs that occur at certain localities along streams and steep hillsides. In the western part of the district some residual soil and a mat of ferns, moss, and bushes cling to the face of nearly vertical cliffs. East of the summit of the Coast Range the regetation is less dense, and though on the borders of the Willamette Valley the north sides of the hills generally are forested with evergreens, the south sides are bare, owing to differences of exposure to the sun and wind.

The dense brush in the lower parts of the Coast Range makes travel on horseback impossible and work, even on foot, very difficult. In many places near the coast it takes one or two hours to walk a mile through the brush.

Many of the wagon roads are very poor, and in winter they are filled with deep mud. Drilling machinery or other heavy material can be moved without much difficulty from June to September, inclusive. In other months there is risk of much delay and expense in transportation except on the few hard roads, such as that from Astoria to Nehalem. In general the main wagon roads lead from the Willamette Valley across the Coast Range to the principal towns near the coast. There are about ten of these roads between. Umpqua 
and Columbia rivers, most of which are poor, although some are being macadamized. Only a few of the wagon roads connect with one another by north-south branches on the coast or in the mountains.

The only railroads that cross the Coast Range in Oregon are the Astoria \& Columbia River Railroad, which follows the south bank of Columbia River to Astoria; the Pacific Railway \& Navigation Co., from Portland to Tillamook Bay; the Corvallis \& Eastern Railroad, from Albany to Yaquina Bay; and the Willamette Pacific, under construction, from Eugene to Coos Bay via the Siuslaw Valley.

\section{GEOLOGY.}

\section{STRUCTURE.}

The Coast Range of northwestern Oregon is a broad, low geanticline of Tertiary formations broken by many igneous intrusions. In most cross sections of the range there are from two to five broad folds of small amplitude, and probably there are many normal faults, of which only indirect evidence can be obtained. Within the range the dips in few places exceed $15^{\circ}$, except near igneous intrusions, and in most places are less than $10^{\circ}$; but along the flanks some dips of $20^{\circ}$ to $35^{\circ}$ have been observed. In other words, the strata have not been sharply compressed. The major axis of uplift, where well defined, lies 5 to 15 miles west of the summit of the range, which in all places is due to the presence of relatively hard igneous rock or sandstone rather than to geologic structure.

South of Umpqua River the higher part of the range, as shown by Diller, is essentially a syncline with flanking anticlines in the upper valley of the Umpqua and near Coos Bay. The syncline disappears north of Umpqua River, and on Siuslaw River the range is essentially an anticline interrupted by many minor undulations, with marginal dips toward the Willamette Valley on the east and the ocean on the west. The same general structure characterizes the range north of Siuslaw River as far as Columbia River and for at least 50 miles into Washington.

The structure of the Coast Range of Oregon and Washington therefore differs markedly from that of the Coast Range of California, where sharp folds prevail. Notably pronounced geologic structure occurs in the northern Coast Range only near the two higher mountain masses in which it terminates; on the south near the Klamath Mountains of southwestern Oregon and on the north near the Olympic Mountains of northwestern Washington.

Contrary to the commonly accepted idea the structure of the Willamette Valley is essentially monoclinal, the dip of the rocks being almost invariably eastward in the widely separated exposures, which are rare except on the valley border. In some places the dip is so slight as to be scarcely perceptible, in others it reaches $25^{\circ}$. In the 
lower valley the average dip is $3^{\circ}$ or $4^{\circ}$; in the upper valley it is $8^{\circ}$ or $10^{\circ}$. A westerly dip has been observed at only one locality, Scotts Mills, on the line between Clackamas and Marion counties, where there is a small monoclinal flexure or fault. Generally speaking, the marine rocks on the east side of the Willamette Valley appear to pass under the lavas of the Cascade Range, within which easterly dips continue for 30 to 50 miles from the valley, but it is possible that there is a large fault along the east margin of the valley and that the marine rocks are later than the lavas of the mountain front.

\section{STRATIGRAPHY.}

\section{AGE OF THE ROCKS.}

The consolidated rocks of the Coast Range of northwestern Oregon are all of Tertiary age. The oldest known strata are about equivalent to the widespread Tejon formation (upper Eocene) of California, above which there are Oligocene deposits, which occupy comparatively small areas and which are in many places absent beneath the extensive Miocene deposits. Pliocene strata are known at only a few isolated localities. The Quaternary material is limited to river bottoms and terraces and to the broad alluvial plain of the Willamette Valley.

No Cretaceous rocks have been found in northwestern Oregon. It was formerly thought that some very poorly preserved fossils, collected by the writer from metamorphosed sediments on the west slope of Marys Peak, were of Cretaceous age, but further study makes it seem probable that they are Eocene. It was also thought that the rocks which J. S. Diller ${ }^{1}$ found unconformably underlying the Astoria shale, opposite Astoria, were Cretaceous or older, but they also are now known to be Eocene.

\section{TERTIARY $\cdot$ SYSTEM.}

EOCENE SERIES.

The oldest known rocks of the Coast Range in northwestern Oregon are of upper Eocene age and carry a fauna similar to that of the Tejon formation of California. No rocks of the age of the Martinez formation of California (lower Eocene) have been found in northwestern Oregon, and in the localities examined by the writer it is highly probable that no strata are older than the Tejon.

In Douglas County the oldest upper Eocene is a thick shale which Diller ${ }^{2}$ has named the Umpqua formation. It is especially well

\footnotetext{
$1 \Lambda$ geological reconnaissance in northwestern Oregon: U. S. Geol. Survey Seventeenth Ann. Rept.,pt. 1, pp. 457, 465, 1896.

${ }_{2}^{2}$ U. S. Geol. Survey Geol. A tlas, Roseburg folio (No. 49), 1898.
} 
developed in the neighborhood of Cole Valley, west of Oakland. North of Umpqua River it has been doubtfully recognized in the Alsea Valley in southwestern Benton County, where a shale is imperfectly exposed beneath the Tyee sandstone.

The most widespread and conspicuous formation of the Oregon Coast Range is the Tyee sandstone, which extends from the type locality in Douglas County ${ }^{1}$ southward to the Rogue River Mountains and northward over 120 miles into Tillamook County. It is not improbable that the upper Eocene on the lower Columbia River is of about the same age. The Tyee sandstone is of medium to coarse grain, in most places thick bedded and highly micaceous. It contains many dull white, mostly subangular grains of decomposed feldspar. Conglomerate is rare in this formation, but some layers contain scattered fine pebbles of quartz and acidic lavas. Locally a few pebbles of more basic igneous rock resemble the diabase of the Roseburg quadrangle. Cross bedding is not common, but ripple murks and sun cracks have been found in the formation on Smith and Siuslaw rivers. Its color is prevailingly light gray, but at the type locality in Douglas County and also in southwestern Polk County, where much of the rock is highly calcareous, it is dark gray. Locally in Lincoln County it is white from the presence of andesitic or dactitic tuff. Marine fossils are abundant at scattered localities at the few horizons where they occur; elsewhere the only fossils are pieces of leaves and wood. Thin beds of lignite are found at a few places, but they have no economic importance unless the coal in the upper and lower Nehalem valleys occurs in this formation, which is not certain. This formation carries some shale, but the shale is very subordinate to the sandstone and is rarely seen, owing to its softness and to the covering of soil and vegetation. The presence of benches on some of the sandstone cliffs, with imperfect exposures of shale, suggests that there may be beds of shale 75 or 100 feet thick. In the cliffs on the Umpqua and Siuslaw rivers some thin partings of shale, a few inches to 10 feet thick, separate massive beds of sandstone 25 to 100 feet thick. Many of these thin partings are minutely contorted, probably from slight movement of the sandstone beds over one another, as the sandstone itself is not affected.

Some vertical sections of the sandstone on the sides of bowlders show many irregular, sharp-cornered little bodies of dark shale, from one-half inch to 2 inches in thickness and commonly about twice as long. Most or all of these are not fragments of an older formation, included as pebbles, but represent clay deposited at the same time as the sand. Evidence of this origin is furnished by filaments of clay, resembling apophyses, which project from the little masses of shale 
for a short distance along the bedding planes of the sandstone, and by micaceous layers which cross both the sandstone and the shale. The manner in which the little shale bodies accumulated is not clear, but it may be that on the original surface of deposition the greater adhesion of clay to clay caused the clay particles to stick to the clay previously formed rather than to the surrounding sand.

The thickness of the Tyee sandstone on the Siuslaw and Alsea rivers is at least 2,000 feet, but its base is not exposed. The formation appears to be over 10,000 feet thick on Umpqua River and Elk Creek, west of Drain, but the strata in that section may be duplicated by faults. The character of the material suggests that much of it is of fluviatile origin, but marine shells found at different horizons at a few widely separated localities cast doubt on this inference. The formation is not divisible on either lithologic or paleontologic grounds and the percentage of fresh-water sediment it contains is uncertain, although the writer believes it is the predominant element of the formation at all localities north of Umpqua River.

In the preceding description the area of the Tyee sandstone has been extended far north of the Roseburg region, in which it occurs as first described by Diller. ${ }^{1}$ This extension appears justifiable, because of the apparent continuity of the sandstone along the Coast Range and because of the many new localities in which the fauna contained in the Tyee sandstone at the type locality (Basket. Point, on Umpqua River) has been found.

The lowest formation outcropping in the Astoria region is of upper Eocene age and consists of a series of diabase tuffs and breccias, which are well exposed in the hills and railroad cuts west of Megler, Pacific County, Wash. The formation also includes a few thin flows of diabasic lava and in its lower part considerable massive sandstone, which is quarried near McGowan station for foundation stones and for use in the revetment work of the Ilwaco Railroad.

The formation is markedly different in texture and composition from the overlying Astoria shale. Its relation to the shale is not certain, but Diller ${ }^{2}$ observed an unconformity below the Astoria shale east of Megler which the writer failed to find. The rock at the locality mentioned by Diller is clay shale interbedded with many layers of sandy shale, which are much harder than the typical Astoria shale and which contain numerous veins of calcite. If there is an unconformity at this locality it will be necessary to consider the hard shale, about 150 feet thick, and 400 feet of underlying sandstone and shale as the top member of the Eocene formation. 
The conformity of the Eocene formation and the Astoria shale is suggested by the structure at the west end of the railroad tunnel at Fort Columbia, where the main body of tuff is overlain, with apparent conformity, by 50 feet of soft clay shale, identical in appearance with the Astoria shale and containing many fossils of a species (Pecten peckhami) that is abundant in that formation and is unknown in the Eocene of Oreagon.

The question of the conformity of the Astoria shale on the Eocene formation must therefore be left open. The age of the latter is determined by the discovery of a characteristic Eocene shell (a hinge of Venericardia planicosta Lamarck) in the fine tuff east of McGowan station.

The formation, which is similar to many others of upper Eocene age in northwestern Oregon and western Washington, is a tuff or agglomerate composed of angular or slightly rounded fragments of basic lava, probably diabase, separated by minute veinlets of calcite. In many places calcite is so abundant that beds of the rock 10 to 20 feet thick have a mottled appearance. The average diameter of the individual ejecta is about half an inch, but some fragments are a foot or more across. Beds of massive coarse gray sandstone occur in the upper and lower parts of the main body of tuff, both above and below which are beds of sandstone nearly 100 feet thick. At several horizons in the tuff, water worn pebbles of diabase sandstone and concretionary limestone are mixed with the angular ejecta. Locally the water worn pebbles are sufficiently abundant to make beds of tuffaceous conglomerate, which in places is so thoroughly indurated that a fracture will pass through both pebble and matrix. Near the middle of the main body of tuff there is a thin sheet of somewhat vesicular basic igneous rock, about 10 feet thick, probably a contemporaneous flow. Near the top of the tuff, in the bed of the first creek west of Megler, there is a basic lava flow, largely fragmental, about 35 feet thick, beneath which is 20 feet of micaceous tuffaceous laminated sandstone full of plant fragments, and above which is 25 feet of hard thin-bedded sandstone. Several dikes of fine-grained diabase, from 2 to 10 feet thick, cut across the tuffaceous strata west of Megler.

The following section was measured from the high river bluff north of Megler, westward along the Ilwaco Railroad tracks to the axis of the anticline near McGowan station. The lower sandstones and much of the tuff is missing from the west limb of the anticline, indicating a fault along the axis with downthrow on the west side, amounting to a stratigraphic displacement of over 1,000 feet. 
Section of Eocene rocks measured along the Ilwaco Railroad between Megler and the Fort Columbia tunnel, Pacific County, Wash.

Clay shale, soft, dark, with Oligocene fossils. Usually referred to as the Aturia zone.

Approximate position of unconformity reported by Diller.

Shale, gray, sandy, hard, with alternating layers of indurated calcareous fine-grained sandstone, one-half to 1 foot thick; some ripple marks; makes high bluff north of Megler; regarded as the top member of the Eocene.................

Clay shale, dark grayish blue, with calcareous concretions......

Sandstone, hard, micaceous, in yellow or gray massive beds, 5 to 15 feet thick, separated by beds of dark clay shale, in places carbonaceous, 3 to 10 feet thick; many small fragments of

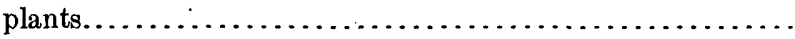

Tuff and agglomerate in massive beds 10 to 30 feet thick, including a few thin beds of tuffaceous quartz sandstone and conglomerate; material, probably mostly diabase; color, dark green on the surface, mottled and veined with white calcite which binds the fragments together. Lower 400 feet poorly exposed. In one of the finer-grained pebbly beds in lower part a worn hinge of Venericardia planicosta was found, asso-

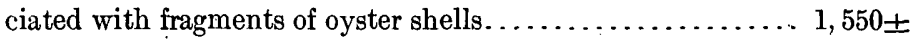

Sandstone, gray-blue, micaceous, coarse grained, massive.....

Agglomerate, angular and slightly rounded fragments of basic igneous rock, 1 inch to 1 foot in diameter................

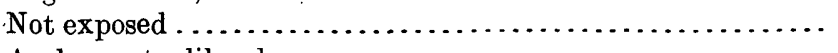

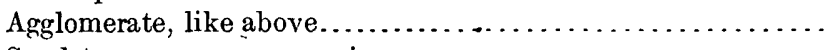

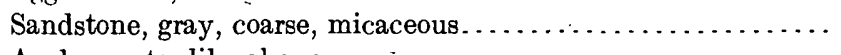

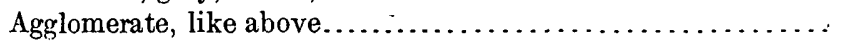

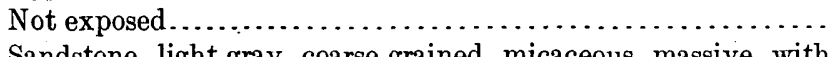

Sandstone, light gray, coarse grained, micaceous, massive, with fragments of deciduous leaves.......................

Agglomerate, like above.............................

Sandstone, gray, coarse, micaceous, some igneous pebbles......

Agglomerate, like above

Feet.

150

50

$350 \pm$

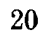

$200 \pm$

10

15

60

$600 \pm$

40

15

8

40

$3,198 \pm$

Beneath the lowest bed of agglomerate lies about 25 feet of shale, very poorly exposed, which is the lowest stratum observed in the Astoria region. No fossils were found in this shale, and it is impossible to say whether or not it belongs to the Eocene, the base of which is indeterminate at this locality.

Basic tuff, identical in appearanoe with the Eocene tuff at Megler, was observed about 30 miles northeast of the type locality, in the small canyon of Chehalis River, half a mile east of McCormick, Wash., on the South Bend branch of the Northern Pacific Railway. The rock shows the same peculiar network seen in the Eocene tuff, consisting of angular fragments cemented together by calcite, and has the same mineralogic composition, texture, and appearance, so far as can be seen with a pocket lens. No fossils were found at this locality and the stratigraphic relations of the rocks are uncertain. West 
of McCormick the Astoria shale outcrops at places along the railroad as far as Frances, a distance of about 10 miles.

The Eocene tuff, containing Venericardia planicosta, near Port Crescent, Wash., ${ }^{1}$ is of similar basic character and general appearance. Diller ${ }^{2}$ has described Eocene basic igneous sediments on Nehalem River, in southern Clatsop County, $2 \frac{1}{2}$ miles below the mouth of Humbug Creek; near Felix Roy's on the same river, about 5 miles east of Nehalem post office; in central Tillamook County, on Wilson and Trask rivers, where the Eocene igneous sediments and lavas form the greater part of the Coast Range; and at a few localities farther south.

Most of the high peaks of the northern Coast Range are formed of intrusive bodies of diabase, rarely of fine-grained diorite, of late Eocene age. Near the top of the Eocene strata there are several big sills or flows of diabase. One of these makes the long, high ridge southwest of Monroe, and others occur in the high hills between Corvallis and McMinnville. The Eocene igneous rocks of the Coast Range are distinguished from the post-Eocene lavas by the greater amount of feldspar, the absence of olivine, and the presence of more or less hornblende. The olivine basalts of the ocean capes and of the Willamette and lower Columbia valleys are all of Miocene or Pliocene age.

\section{OLIGOCENE SERIES.}

OCCURRENCE AND CHARACTER.

The known marine Oligocene rocks of the Coast Range of Oregon are limited to three northernmost counties-Clatsop, Columbia, and Tillamook. Fossils, referred with doubt to the Oligocene, were collected by Diller ${ }^{3}$ farther south, at a point 8 miles northeast of Dallas, Polk County, and at Blodgett, Benton County.

The oldest marine rocks of the Cascade Mountains in northwestern Oregon are probably of Oligocene age, according to determinations made by Ralph Arnold of fossils collected by the writer in 1903 in the bed of Coal Creek, near its junction with Butte Creek, southern Clackamas County. At this locality the Oligocene strata consist of clay shale containing thin beds of impure shell limestone, which is burned to make lime, overlain by sandy shale containing beds of sandstone 1 foot to 3 feet thick, from which the fossils were obtained. About 400 feet of marine strata is exposed, above which, in apparent conformity, lie 600 to 700 feet of sandstone, conglomerate, and shale, evidently of fresh-water origin, and containing thin beds of coal. Above the coal-bearing rocks are basic lavas.

1 Arnold, Ralph', A geological reconnaissance of the coast of the Olympic Peninsula, Wash.: Geol. Soc. America Bull., vol 17, pp. 451-468, 1906.

2 Diller, J. S.; $\Lambda$ geological reconnaissance in northwestern Oregon: U. S. Geol. Survey Seventeenth Ann. Rept., pt. 1, pp. 456-457, 1896.

Idem, p. 467. 
The Oligocene strata dip about $5^{\circ} \mathrm{E}$. They rest on basic igneous rock, which continues 6 miles down the canyon of Butte Creek to Scotts Mills, where it is unconformably overlain by conglomerate and sandstone containing Miocene fossils. It is probable that the igneous rocks are later than the Oligocene strata, for the latter contain only pebbles of more acidic lavas and are themselves cut by several dikes of basic igneous rock identical in appearance with the rock in the lower canyon.

On the east side of the Willamette Valley no marine Oligocene rocks are known south of the locality on Coal Creek, Marion County, already described. Fresh-water beds of Eocene or possibly Oligocene age occur in Lane County on the lower western slope of Mount Tom, on the old Murch homestead east of Coburg, and at the coal prospect east of Creswell. A large collection of well-preserved plants from the lower part of these beds, obtained in the wagon road about 3 miles north of Goshen, was examined by F. H. Knowlton, who reports that the species are nearly all new forms, most closely allied to the flora of the upper Eocene. ${ }^{1}$ This is surprising, for the leaf-bearing beds dip eastward and are found east of the eastward-dipping Miocene ${ }^{2}$ for about 50 miles along the western foothills of the Cascade Mountains. Small faults are abundant, judging from the meager evidence of poor and widely separated outcrops; and there is some indication that a large fault, similar to the one that has explained a like problem in the Connecticut Valley, ${ }^{3}$ occurs on the eastern border of the Willamette Valley. The evidence for this fault, however, is not conclusive, as the fault plane has not been seen and the strata of the upper division of the marine Miocene have not yet been found repeated east of its supposed locality. The strata on the west side of the supposed fault are eastward-dipping marine Miocene of the upper division, and although many of the strata are concealed beneath the alluvium of the valley it is probable from a doubtful estimate made near Eugene that the strata of the upper division are more than 3,000 feet thick. On the east or upthrown side of the fault these strata have not yet been found, and their absence can be explained only by assuming that the fault is close to the shore line that prevailed during the deposition of the upper division, and that most of the remnants of that division have been removed by erosion on the upthrown side. In Lane County the strata on the east side of the supposed fault are eastward-dipping fresh-water strata and the fault is postulated because the fossil leaves indicate that the fresh-water beds are older than the marine formations on the west side.

1 See Knowlton's report in this bulletin, p. 36.

2 Recent work by Arnold and Hannibal (Am. Philos. Soc. Proc., vol. 52, pp. 559-605, 1913) leads them to call these strata Oligocene.

3 Davls, W. M., and Griswold, L. S., Eastern boundary of the Connecticut Triassic: Geol. Soc. America Bull., vol. 5, pp. 515-530, 1894; also U. S. Geol. Survey Eighteenth Ann. Rept., pt. 2, pp. 9-192, 1898. 
The best exposures of the older strata are on the west face of the Coburg Hills, at the foot of which are lower sandstone hills with marine fossils of the upper division of the Miocene. The best collections were obtained in two conspicuous points that project like capes from the higher range into the valley, one of the points being on the Van Dyne place about 2 miles northeast of Coburg, and the other being West Point, on the Linn County line. The marine Miocene reappears with a meager fauna on the sides of Petersons Butte, a volcanic neck standing in the valley near Lebanon, Linn County. The fauna includes Venericardia castor, which is regarded as an Oligocene form in northwestern Washington. Possibly the igneous intrusion has upturned the strata, bringing a lower horizon to the surface, but the almost complete absence of outcrops prevents the elucidation of the structure of the volcanic necks of Linn County.

The position of the fault here is unknown, but apparently it passes east of Twin Butte, 3 miles south of Brownsville, where the upper division of the Miocene is well exposed, dipping between $5^{\circ}$ and $10^{\circ} \mathrm{E}$., and west of an exposure of leaf-bearing shale on the Corvallis \& Eastern Railroad near Lyons station. In Marion County the fault has not been located, but it is possibly represented by the sharp flexure at Scotts Mills, 6 miles southeast of which, above the basalt canyon, east-dipping marine Oligocene or lower Miocene outcrops. The strata of the upper division rest unconformably on the basalt at Scotts Mills and $\operatorname{dip} 10^{\circ}-20^{\circ} \mathrm{W}$. A similar flexure, in line with the preceding localities, is indicated possibly by. the steep westward dip $\left(20^{\circ}\right)$ observed on Clackamas River, 6 miles northeast of Oregon City, in tuffaceous sandstone and volcanic agglomerate. The existence of the hypothetical fault along the eastern border of the Willamette Valley depends on the prevailing opinion of the age of the marine sediments of Willamette Valley. If these are not Miocene, but are lower Oligocene, as recently stated by Arnold and Hannibal, ${ }^{1}$ the necessity of postulating a fault vanishes.

Astoria shaLe (OLIGOCENE AND MIOCENE).

The Astoria shale, so named by Thomas Condon, ${ }^{2}$ is stratigraphically an indivisible lithologic unit, being a homogeneous mass of darkcolored marine shale. The lower 400 feet or more is of Oligocene age and the remaining 1,000 feet or less is Miocene, probably lower Miocene. In the field there is no way of distinguishing the two parts of the formation. So many fossil species pass across the invisible dividing line that a collection made below the top of the Aturia zone (Oligocene) at Knappton, Wash., opposite Astoria, has been referred to the Miocene. Aturia angustata, which is regarded as typical of the Oligocene, has been found in concretions from 300 to 400 feet above 
the base of the formation. Dall ${ }^{1}$ later used the expression "Astoria group" for both the Miocene shale and overlying sandstone, excluding the Oligocene part of the shale. The name Astoria is used in this paper only for the shale lying above the Eocene strata and below the massive sandstone of Harrington Point. This usage, corresponding to the first definition of Condon and to the use of the term by Diller, includes the Oligocene shale as part of the formation. This part may be referred to as the Aturia zone of the Astoria shale, since it is not definitely recognizable except by the presence of the rare Aturia fauna.

The Astoria shale or its fossils were studied first by J. D. Dana ${ }^{2}$ and T. A. Conrad, ${ }^{3}$ and later by C. A. White, ${ }^{4}$ W. H. Dall, ${ }^{5}$ J. S. Diller, ${ }^{6}$ and by Arnold and Hannibal. ${ }^{7}$ Recently Dall has published an extensive description of the Astoria fossils, ${ }^{8}$ including species that occur at the bottom of the Astoria shale as well as others. from the overlying Miocene sandstone of Smith and Harrington points.

The lower part of the Astoria shale is best seen on the north bank of Columbia River, near Knappton, where the shore for about 3 miles is composed of large but discontinuous outcrops of shale, mostly in low bluffs flanking little headlands formed of basalt dikes. Faults of unknown throw (each under 500 feet) occur in at least two of the intervening valleys. The shale is prevailingly dark, fine, clay shale, with many lighter-colored highly calcareous layers and some thin siliceous lenses. Near the base sandy shale is common and a few thin beds of fine-grained hard micaceous sandstone appear. Aturia angustata is characteristic of the lower 400 to 500 feet of the shale, and for this reason the lower part is called the Aturia zone. The thickness here given is only an approximation, since it is practically impossible to tell how far the scarce aturias range within the shale, and, moreover, the throw of the faults which repeat the outcrops of the Aturia zone is not known.

Calcareous concretions, common at many horizons in the Astoria shale, are especially abundant in the Aturia zone. The concretions were formerly used in making cement at the abandoned town of Cementville, a mile north of Knappton, Wash., opposite Astoria, where they are so numerous as to compose almost exclusively the shore gravel or shingle. The concretions are from 3 to 18 inches in diameter, nearly spherical, light gray on the surface and bluish gray to black on fresh fractures, very hard, dense, and fine grained.

\footnotetext{
1 Dall, W. H., Correlation papers-Neocene: U. S. Geol. Survey Bull. 84, p. 224, 1892.

2 Wilkes exploring expedition, vol. 10, p. 653.

${ }^{3}$ Idem, pp. 722-729; also Am. Jour. Sci., 2d ser., vol. 5, pp. 432-433.

4 U. S. Geol. Survey Bull. 51, pp. 31-32, 1889.

5 U. S. Geol. Survey Bull. 84, p. 224, 1892.

6 U. S. Geol. Survey Seventeenth Ann. Rept., pt. 1, pp. 469-475, 1896.

7 Am. F'hilos. Soc. Pros., vol. 52, p. 575, 1913.

8 Dall, W. H., The Miocene of Astoria and Coos Bay, Oreg.; U. S. Geol. Survey Prof. Paper 59, 1909.
} 
Silica in the form of chert has replaced part or all of the lime in the nuclei of many of these concretions; and higher up, in the central part of the Astoria shale, chert reappears as scarce thin, short, impure lenses and concretions. The largest lens observed is about 3 inches thick and 5 feet long. The source of this silica is uncertain. One thin section of the chert examined under the microscope showed no traces of diatoms or radiolarians. Very possibly the remains of such minute organisms have been destroyed in the process of solution and redeposition by which the silica was segregated into the concretionary form. The chert is rare, and even if it be composed of organic silica it can not indicate the previous existence of much diatomaceous earth in the Astoria region.

The upper 300 feet or more of the Astoria shale has been seen only imperfectly in small widely separated outcrops in the west end of Astoria and in the head of Grays Bay. The central mass of the shale, however, is now excellently exposed in the deep-grade cuts of the Astoria streets, where it is shown to be a predominantly gray or black clay shale, locally containing sufficient carbonaceous matter to furnish traces of inflammable gas when heated. It is evenly stratified, mostly in thin beds, dipping normally from $5^{\circ}$ to $15^{\circ} \mathrm{S}$., but has been greatly disturbed by landslides, which in places affect its structure to a depth of at least 50 feet.

Sandy layers, which are common near the top and bottom of the formation, are subordinate in this central part. Beds of thin, soft argillaceous sandstone are seen in a few excavations, but do not outcrop conspicuously. In one exposure on Grand Avenue there is about 30 feet of soft, bluish sandstone in beds 3 to 10 inches thick, separated by equal thicknesses of sandy shale. The sandstone is fine grained and argillaceous, with minor irregularities of structure resembling imperfect cross-bedding.

Sandstone dikes are very abundant. Probably not less than a hundred may be seen in Astoria, and if similar exposures could be had probably as many would appear in the surrounding country, where a number have been found. The width of the dikes varies from a foot or less up to 10 feet. Their prevailing trend in Astoria is between N. $50^{\circ}$ W. and N. $10^{\circ}$ E., with exceptional departures to other points of the compass. The dip of most of the dikes is between $60^{\circ}$ and $90^{\circ}$. They are composed of coarse, loosely consolidated sand grains and abundant flakes of white mica. Most of them show irregular, rude jointing, as well as joints approximately parallel to the bedding planes of the inclosing strata, and some show indications of a few close-spaced joint planes parallel to the walls. The latter are due to shearing along the dikes, many of which have slickensided walls; but the joints parallel to the stratification may be due either to shearing stresses $47196^{\circ}-$ Bull. $590-14-2$ 
transmitted by the strata or to unequal desiccation resulting from the varying porosity or water content of different strata. Minor features of structure suggest that the dikes were filled from below when the sand was more or less plastic and mixed with much water. The great abundance of mica suggests that the sand came from the heavy sandstone at the top of the underlying Eocene strata, but some doubt is cast on this idea by the greater rarity of dikes in the lower part of the formation where exposed between Megler and the United States quarantine station across Columbia River. The abrupt upward termination of some dikes is an especially potent argument for their deep origin, and the fact that little apophyses and stringers of the sand were forced for many feet through joint fissures one-half inch or less in width indicates that the sand was injected under high pressure. One sandstone dike 4 to 6 feet in width may be traced through a vertical distance of about 150 feet on the Astoria hillside. It is incredible to think that such a fissure, now inclined with a dip of $70^{\circ}$, could have formed and remained open in the soft shale while being filled from above. It is more plausible to think that the loose watercharged sand entered a narrow fissure from below under high pressure and gradually forced the walls apart. This view is in harmony with that of Diller, ${ }^{1}$ who compared the sandstone dikes with similar ones in Tehama County, Cal., of which he had made an exhaustive study, ${ }^{2}$ but it is opposed to the original observations by Dana ${ }^{3}$ on the Astoria dikes.

Aside from their purely scientific interest the sandstone dikes bear directly on the occurrence of oil by demonstrating the fractured condition of the Astoria shale. The asphaltic sandstone dikes of southern California show that these structures are comparatively open, porous channels for the migration of oil. Previous considerations indicate that the Astoria dikes extend far downward, probably to the base of the shale. One would think, therefore, that if much free oil had ever existed in the shale or underlying sandstone it would have escaped through the sandstone dikes, leaving hydrocarbon residues of some kind, but none have been found. As far as it goes, the testimony of the sandstone dikes is adverse to the belief that there are underground oil reservoirs in the Astoria region.

Some of the layers in the central part of the Astoria shale contain many minute shells of Foraminifera and Rhizopoda, little white pellets, disks, and spindles scattered over the bedding planes, but not in sufficient quantity to make marl or other very calcareous rock.

In the same part of the formation are two or more beds of "greensand" 3 to 6 feet thick. This is a bright-green oolitic rock, which

1 U. S. Geol. Survey Seventeenth Ann. Rept., pt. 1, p. 469, 1896.

2 Sandstone dikes: Geol. Soc. America Bull., vol. 1, pp. 411-442, 1890.

a Dana, J. D., Wilkes exploring expedition, vol. 10, p. 653. 
has the same appearance and qualitative composition as the greensands of the New Jersey Coastal Plain. It is well exposed in the cut at the northeast corner of Irving Avenue and Thirteenth Street, Astoria, where it is accompanied by soft, white, chalky porous concretions, greatly altered by weathering from an originally dense condition. The green oolitic grains are locally abundant in many of the layers of sandy shale on both sides of the Columbia. At Knappton and in the cut at Harrison and Tenth streets, Astoria, they have been cemented together by the comparatively pure lime carbonate of the first period of concretionary growth. Presumably, therefore, the green granules were formed either on the ocean bottom or in the sediments soon after deposition.

Landslides have occurred on practically every hill composed of the Astoria shale. In the excessive rainfall of the wet winter months the joint and bedding planes of the shale are thoroughly lubricated with water and the rock creeps slowly downhill, doing great damage to sewers, pavements, and houses. Many house foundations are cracked; some buildings are tilted, with walls askew; and chimneys and stone fences have been destroyed by the gradual creep of the shale. A few sudden slides have occurred, with more spectacular but less costly damage to the city as a whole. In many places no noticeable movement has taken place since the building of the city, numerous buildings having stood undamaged on the hillside for over 50 years. Yet the hummocky hillside, showing typical old landslide topography, indicates that sliding has occurred at some time in nearly every part of the city.

The Astoria shale is not recognizable with certainty south of Clatsop County. Rocks of probably the same age occur in Tillamook County, but both the Oligocene and lower Miocene, where determinable, are largely sandstone with subordinate shale. Farther south the rocks are even more exclusively sandstone. On the east side of the Coast Range the same remark holds true in a general way; but Oligocene and lower Miocene rocks are not known south of the Blodgett Valley in Benton County. The shale reaches its best development near the mouth of Columbia River, from which it extends southeastward to Nehalem River and northeastward at least to Pluvius and Frances on the South Bend branch of the Northern Pacific Railway. Farther north it has not been recognized; but a related fauna in a thinner and more sandy formation was found by Ralph Arnold ${ }^{1}$ and the writer on the south shore of the Strait of Juan de Fuca.

A small lot of Oligocene fossils; including Aturia cf. angustata Conrad, has been received from W. A. Abernathy; of Seattle, who 
writes that he collected them from sandstone in the big cut made by the Chicago; Milwaukee \& St. Paul Railway 2 miles west of Rochester, Wash. The sedimentary rocks of that region, as shown both by outcrops and by the logs of deep wells; are almost all sandstone. The Oligocene fauna is also known at Port Blakely, on Puget Sound, opposite Seattle.

\section{MIOCENE SERIES. 1}

OCCURRENCE AND. CHARACTER.

Marine strata of Miocene age are extensive in northwestern Oregon, both in the Coast Range and along the western base of the Cascade Mountains. On account of the abundance of fossils in the Miocene; strata of that age are the most readily recognizable, and nearly four-fifths of the known fossil localities in northwestern Oregon have been referred to the Miocene by Dall. 'About the Willamette Valley the rocks are predominantly Miocene; in the Coast Range; on the other hand, the sandstones of upper Eocene age appear to have a much wider distribution than the Miocene and to cover a greater area than rocks of any other age. Unfortunately the recognition of the Eocene sandstones depends largely on lithologic and stratigraphic relations, fossil localities being rare and widely separated.

In order of relative abundance the Miocene strata consist of sandstone; shale, tuffaceous rocks, and conglomerate. Coarse material is greatly in excess of fine, especially in the upper part of the Willamette Valley and along the western foot of the Cascade Mountains.

Wherever the Miocene rocks have been studied with much care they may be divided on lithologic grounds into more or less distinct formations, but the strata are so extremely variable in character that such divisions can not be recognized for any great distance. The complete classification of the Miocene strata will depend chiefly on paleontology and will require detailed stratigraphic work over a large area. For this reason it seems best not to attempt to subdivide the Miocene into formations at the present time.

Most of the uncertainty in subdividing the Miocene of Oregon is probably due not so much to the poor preservation of the fossils as to the comparative uniformity of physiographic conditions throughout the middle Tertiary and to the lack of much deformation at that time. This is in sharp contrast to the conditions in southern California in mid-Tertiary time, where a great thickness of sediment was deposited with several epochs of deformation and consequent shifting of faunas. At that time comparatively tranquil conditions

\footnotetext{
! Recent work by Arnold and Hannibal (Am. Philos. Soc. Proc., vol. 52, pp. 590 et seq., 1913) leads them to classify these rocks as Oligocene.
} 
prevailed in Oregon; there was no great relief to promote the transportation of sediment and no marked deformation or other causes to induce great changes in the faunas, which underwent only gradual modification. As in the Sacramento Valley ${ }^{1}$ of California, the sea occupied little of the Willamette Valley south of Washington and Polk counties in Oligocene time, but later, in Miocene time, the sea reached the head of the valley near Eugene, and according to an observation by Diller ${ }^{2}$ it may possibly have extended into Douglas County. The writer has not been able to find recognizable Miocene fossils more than 10 miles south of Eugene, although some of the barren strata on the headwaters of Siuslaw River west of Cottage Grove are similar in appearance to the Miocene of the Willamette Valley and contain a few casts suggestive of Spisula albaria, which is very abundant in the Miocene of the valley.

In the lack of detailed information which would permit the description of the Miocene under formation names; the stratigraphy and paleontology make it desirable to recognize not more than two more or less distinct divisions, provisionally called the upper and lower divisions, of the marine Miocene of Oregon. The paucity of strictly comparable fossils prevents exact correlation of these divisions with the Miocene formations of California or other regions. The terms are convenient mainly in indicating the relative position of strata in the stratigraphic column of northwestern Oregon.

LOWER DIVISION OF THE MIOCENE.

The lower division is regarded as of lower Miocene age because it contains many species in common with the Astoria shale, which it overlies with apparent conformity. In Clatsop County, Oreg., and across Columbia River, in Pacific County, Wash., the line of separation between the Oligocene and the Miocene lies somewhere within the Astoria shale (see pp. 15-20), which, according to Dall, is partly Oligocene and partly lower Miocene.

With the Oligocene it forms a conformable sequence of strata also in Columbia County. Elsewhere the relations of the lower division to the Oligocene are not known, but the lower division has not been recognized south of Polk County.

On Dairy Creek, Washington County, a locality first examined by Diller, ${ }^{3}$ soft massive sandstone belonging to the upper division of the Miocene appears to be conformable on the shale and thinbedded sandstone of the lower division. This contact has not been found in other regions, but farther south, in Benton and Lane

\footnotetext{
1 Arnold, Ralph, Environment of the Tertiary faunas of the Pacific coast: Outlines of geologic history (Willis and Salisbury), pp. 237-238.

${ }^{2}$ U. S. Geol. Survey Seventeenth Ann. Rept., pt. 1, p. 472, 1896.

${ }^{3}$ Idem, p. 471.
} 
counties, where the supposed base of the upper division is generally conglomeratic, there is some indication that it is unconformable on the underlying strata. The latter, however, have not yet yielded a determinable lower Miocene fauna, but only a few fossils which are Eocene in Benton County and probably Eocene in Lane County, north of Elmira. It therefore appears that there is a hiatus below the Miocene strata of the upper valley, and that the lower division of the Miocene was never deposited or was removed by erosion before the strata of the upper division were laid down. This opinion is tentative rather than conclusive, because exposures on the west side of the upper valley are exceedingly poor and do not furnish sufficient recognizable fossils to warrant a decision.

Southeast of Elmira and west of Spencer Butte there is a group of strata, over 1,000 feet thick, containing a few thin beds of coal, which does not appear farther north along the west side of the valley where it would be expected. This group lies below the upper division of the Miocene, but whether it should be included in that division or in the lower division of the Miocene is uncertain. The rocks are mostly coarse tuffaceous sandstones nearly. barren of fossils other than petrified wood, which is abundant. At one locality, on the Owen farm, on Spencer Creek, 10 miles southwest of Eugene, the following fossils were obtained from this lower group: Venericardia castor Dall; Angulus oregonia Dall, Crassatellites sp.?; Macoma sp.; Cardium sp.; Trochita inornata Gabb; Bittium? sp; Pecten sp. The Venericardia is suggestive of a lower horizon, but it occurs at the base of the upper division at Scotts Mills, Marion County, also on Peterson Butte, Linn County. The rest of the fauna is not decisive, and the correlation of this group of strata is therefore left for future determination.

The lower division consists mostly of fine-grained marine rocks in Clatsop, Columbia, and Washington counties. At all localities in these counties the higher part of the division is more sandy than the lower, and in Tillamook County hard massive sandstones lie at the top of the shaly member and make conspicuous outcrops on Tillamook Bay. Massive marine sandstone with sandy shale that probably belongs in the lower division of the Miocene outcrops at Huntington Point, Smith Point, Tongue Point, and other places in the estuary of Columbia River. The sandy strata lie at the top of the Astoria shale; but whether they are conformable or not is uncertain. In neighboring exposures sandstone has been observed resting unconformably on the Astoria shale, but at these places no marine fossils could be found above the unconformities, and the overlying sandstone was thought to be fresh-water post-Miocene. The Astoria shale, of which the upper 1,000 feet or more belongs to the lower Miocene, has already been described. The sandstone and sandy shale above the Astoria shale, which also probably belongs in the 
lower division of the Miocene, is between 200 and 300 feet thick where best exposed, but is broken and overlain by lava on the lower Columbia. The thickness of the lower division in Columbia and Washington counties can not be determined with the data at hand; but it probably does not exceed the thickness in Clatsop County. In Columbia County the strata of this division are much more sandy than in Clatsop County, but shale still predominates, containing many fossil shells similar to those found at Astoria. In Polk County (see pp. 87-89) sandstone belonging to the lower division of the Miocene is fairly well exposed and overlies shale which may be either lower Miocene or Oligocene. South of Polk County the lower division has not been recognized, but it may be represented by the fresh-water material near Goshen and Coburg, Lane County, which was described under the Oligocene. (See p. 14.)

Most of the known fauna of the lower division is included in the list of fossils from the Astoria shale given by Dall. ${ }^{1}$ The fauna of the lower division in Columbia County is essentially the same, although not nearly so rich, so far as now known. A somewhat different fauna containing several species not known elsewhere in the Willamette Valley, is found near Crowley station in northeastern Polk County. The fossils were collected in four lots from about 50 feet of conformable strata at the ranch of A. M. Home, 3 miles south of McCoy, Polk County, Oreg. The list of species, determined by Dall, comprises Fusinus oregonensis Conrad?, Trochita cf. radians Lamarck, Dentalium conradi Dall, Acila conradi Meek, Molophorus cf. gabbi Dall, Litorina cf. gigantea Middendorf, Diplodonta cf. parilis Conrad, Mactra cf. delumbris Conrad, Neverita cf. inezana Conrad, new species of Lacuna and Donax, and undetermined species of Thais, Lunatia, Saxidomus, Spisula, Chione, Macoma, Scala, and Bela. At the same locality Diller ${ }^{2}$ found Tritonium californicum Gabb, Trochita filosa Gabb, Cuma biplicata Gabb, Clavella grabida Gabb?, and undetermined species of eight other genera.

UPPER DIVISION OF THE MIOCENE.

The strata of the upper division of the Miocene are in general more sandy than those of the lower division and are in many places conglomeratic, especially at the base of the upper division, as on Hemenways Butte, 6 miles west of Eugene. Beds of tuff, tuffaceous sandstone, and in a few places coarse volcanic agglomerate are abundant. The shale is nearly all sandy. Pure clay shale like that in the lower division is rare. The sandstone is prevailingly soft, thin bedded, yellowish weathering, and does not make any conspicuous outcrops about the Willamette Valley. In the valley sandy shale is probably

1 U. S. Geol. Survey Prof. Paper 59, p. 12, 1909.

2 U. S. Geol. Survey Seventeenth Ann. Rept., pt. 1, p. 467, 1896. 
the preponderant rock of the upper division, but sandstone is locally more abundant. The rocks of the valley are principally marine.

In the Coast Range are many exposures of massive fresh-water sandstone which is probably of Miocene age, but its thickness and stratigraphic relations have not been determined. Locally it contains beds of coal too thin to be of any value.

The thickness of the strata of the upper division is not known accurately. Generally the base is on the west side and the top on the east side of the Willamette Valley, the dips being eastward on both sides. The central part of the valley, covering the greater part of the cross sections, is covered by Quaternary clay and gravel, under which the structures are wholly problematic. Near Eugene the Miocene outcrops at intervals along the foothills on the south side of the open valley for an east-west distance of at least 4 miles and a persistently eastward dip of $2^{\circ}-22^{\circ}$ (average probably $10^{\circ}$ ), indicating that its probable minimum thickness is 3,600 feet. Several outcrops about Gillespie and Skinner buttes, in the open valley, indicate that east dips exist under the ailuvial cover of the valley. The writer has little confidence in the accuracy of this estimate, because of the many basalt dikes which cut the strata and because of the small faults indicated at many localities by slickensides and similar phenomena. It is quite probable that these faults have repeated the strata, but the true amount of reduplication of the strata by faulting can not be determined. The strike of the strata in this section is somewhat variable between N. $20^{\circ}$ W. and N. $40^{\circ} \mathrm{E}$., but in most places it is nearly north and south.

The relations of the upper division of the Miocene to the lower division have been described in considering the lower division. (See p. 21.) The relations to the overlying rocks are unknown, since no certainly overlying Tertiary formations have been seen. The upper division is capped at many localities in the lower valley by flows of basalt and of hornblende and hypersthene andesites, more commonly the first. It is also cut by many dikes, necks, and sills of basalt, mostly olivine basalt.

When they were examined, several years ago, the fresh-water rocks immediately east of the upper division of the Miocene were thought by the writer to occupy the higher position in the stratigraphic column. This is the normal sequence suggested by the dips. It now appears, however, that the fresh-water beds are older than the marine, according to a report of Knowlton on the fossil leaves, in which an Oligocene or lower Miocene age is indicated. There must be an unconformity or a large north-south fault, or more likely both, on the east side of the upper valley, in southern Linn County and in Lane County at least as far south as Goshen, in order to explain the anomalous relations of the outcrops. 
The fauna of the Miocene of the Willamette Valley is quite different in general aspect from that of the Miocene along the coast. The difference is especially marked in the upper valley, in Lane and Linn counties, where the pectens and the large arcas and cardiums so common along the coast are almost wholly lacking, although the latter genus is represented by diminutive forms. ${ }^{1}$ Nearly every exposure in the upper valley shows an abundance of Hemimactra, Mulinia, Solen, small Crepidula, and Trochita, which are more rare on the coast. This difference, so far as it applied to the fossils of the upper division of the coastal Miocene, is only a difference of faunal facies. The partly inclosed shallow waters of the valley harbored a different life from that on the open coast.

The largest fauna of the upper division in the Willamette Valley comes from near Eugene. It is embraced in collections made by the writer, between 1898 and 1905, along an interrupted outcrop of about 3 miles, between College Hill and Springfield. The collections all represent essentially the same fauna, and every species found at the top of the section at Springfield occurs also at the base of the section at College Hill. Most of the species occur at all the intermediate outcrops, so that there can be no error in placing them all in the same list. The writer is indebted to W. H. Dall for the determination of the species in the following table:

Fossils from the upper division of the Miocene, Eugene, Oreg.

\begin{tabular}{|c|c|c|c|}
\hline & Eugene. & Coos Bay. & Astoria. \\
\hline 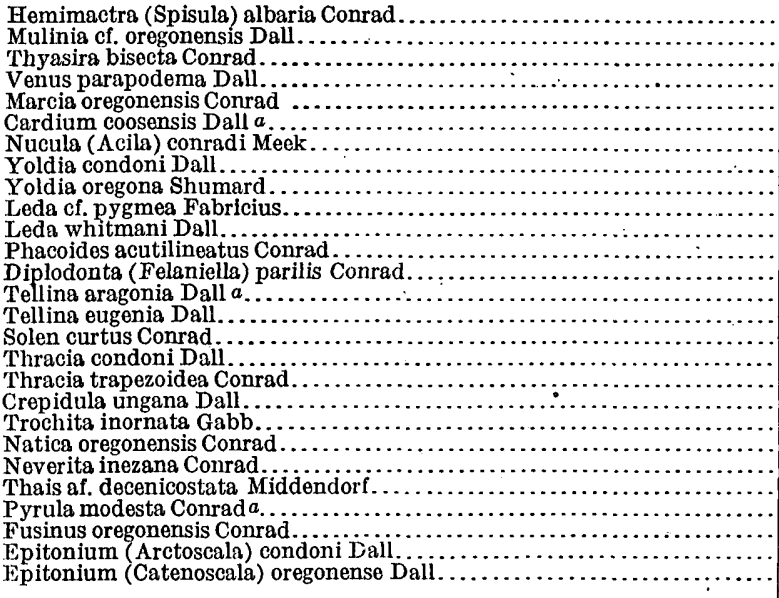 & $\begin{array}{l}x \\
x \\
x \\
x \\
x \\
x \\
x \\
x \\
x \\
x \\
x \\
x \\
x \\
x \\
x \\
x \\
x \\
x \\
x \\
x \\
x \\
x \\
x \\
x \\
x \\
x\end{array}$ & 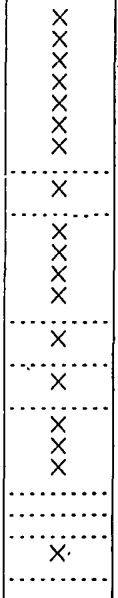 & 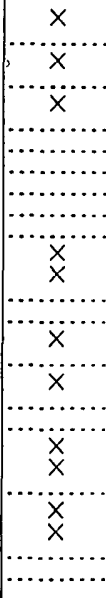 \\
\hline
\end{tabular}

$a$ Species regarded by Arnold and Hannibal as characteristic of the Empire formation (Miocene). See Am. Philos. Soc. Proc., vol. 52, p. 590, 1913.

There are also new species of Acteon, Dentalium, Ilyanassa, Lima, Mytilus, Modiolus, Pecten, Solen, and Sanguinolaria; and unde-

1 Recently A. J. Collier has found a specimen of Pecten, apparently a new species related to P. wrishburnei Arnold, in the green upper Miocene tuffs at Kelly Butte, Springfield, Oreg. 
termined species of Macoma, Schizothoerus, Chione, Pteria, Ostrea, Mya (?), Paradione, Cancellaria, Xylotrya, Lyonsia (?), Chrysodomus, Bittium, Ceritheum, Turritella, Lamna, Balanus, and four species of ostracods. An echinoderm from the same beds (Condon Museum, University of Oregon) was referred to Scutella gabbi Rémond by J. C. Merriam. A critical study of the fossils in the Condon Museum would slightly extend the list.

The isolation of this fauna is shown by the presence of at least 18 species, 9 of which are new, that have not been found at Astoria and Coos Bay. Many of these peculiar forms are found at localities farther north in the Willamette Valley, near Lebanon, Salem, and Oregon City, and are the most characteristic species by which the upper division of the Miocene may be recognized in the lower valley.

The fauna offers little ground for comparison with those of southern California, which is the only part of the Pacific coast where complete faunal and stratigraphic studies have been made. It bears greater resemblance to the Miocene faunas near Humboldt Bay in northern California and near Coos Bay in southern Oregon. Of the 27 determined species 18 are found in the Miocene of Coos Bay and at least 4 others bear close resemblance to Coos Bay forms figured by Dall. ${ }^{1}$ Twelve of the determined species occur near Astoria, but the collections made near that place in 1910 show that three of these are found only at the top of the Astoria section, and three others are known to have little diagnostic value because of their wide range.

The unconformity at Scotts Mills, Marion County, which separates the upper division of the Miocene from Oligocene or lower Miocene strata, strengthens the paleontologic evidence of the richer fauna at Eugene in showing that the upper division of the Miocene is younger than the Astoria shale and possibly younger than the sandstones immediately above the Astoria shale. Similar evidence has been obtained in Columbia County. Evidently the fauna is intermediate between that of the Astoria shale (Oligocene and lower Miocene) and the Empire formation (Miocene), and the writer believes that the strata are of intermediate age.

The fauna of the upper division is most closely allied in related forms to the upper Miocene of California, but exact correlation is not possible. The position of the Miocene of Coos Bay, which is most closely allied to the fauna at Eugene, is left open by Dall ${ }^{2}$ but is upper Miocene according to a correlation table recently published by Arnold. ${ }^{3}$. The upper division of the Miocene of Willamette Valley

\footnotetext{
1 U. S. Geol. Survey Prof. Paper 59, p. 12, 1909.

2 Op. cit.

${ }^{3}$ Arnold, Ralph, Environment of the Tertiary faunas of the Pacific coast: Outlines of geologic history (Willis and Salisbury), pl. opposite p. 250 .
} 
may therefore be considered tentatively as upper Miocene. Both stratigraphy and paleontology indicate that it is higher than the Astoria shale. ${ }^{1}$

\section{PLIOCENE SERIES.}

In no phase of western Oregon geology is the contrast with California-more marked than in the rocks of Pliocene age. In California the Pliocene rocks are abundant, largely marine, and very thick, and they are folded and faulted. In Oregon marine Pliocene rocks are very rare, occurring so far as known only at a few widely separated localities (found by Diller), and they are very thin, loosely consolidated, and remain practically as level as they were when deposited, although their present altitude at places indicate that they as well as the Pleistocene sediments have been elevated since deposition.

The only known marine Pliocene in northwestern Oregon occurs in Columbia County south of Clatskanie, and the only known Pliocene tuffs occur on Rock Creek. ${ }^{2}$ Between Columbia County and Coos Bay, in the southwestern part of the State, no marine Pliocene has been found. The shore line during this epoch was probably west of its present position except for an inlet which permitted the sea to reach the upper Nehalem Valley.

Fresh-water deposits of Pliocene age, common in eastern Oregon, are rare in the western part of the State. A camel's tooth (Auchenia) found in the clay on Portland Heights has suggested that this clay is of Pliocene age, but the evidence.is not conclusive.

\section{PALEONTOLOGIC DATA.}

\section{MARINE FOSSILS.}

The following paleontologic records will assist students who may hereafter endeavor to unravel the hidden structures and the detailed stratigraphy of northwestern Oregon. The locality number of each collection is the accession number under which the collection is preserved in the United States National Museum in Washington. These numbers are given in parentheses where they appear in the text of this report. For the determination of the marine fossils the writer is indebted to W. H. Dall.

5314. Tenth and Harrison streets, Astoria:

Foraminifera.

Dentalium, 2 sp., probably $\mathrm{D}$. conradi and D. petricola Dall.

Cylichna sp.

$\Lambda$ cmæa? sp.

Lima sp.

Pseudamusium peckhami Gabb.

Pseudamusium randolphi Dall.

-Propeamusium n. sp.

Acila sp.

Malletia sp.

Periploma? sp.

1 Arnold and Hannibal express a very different opinion, placing the writer's upper division of the Miocene as equivalent to the San Lorenzo formation (Oligocene) of California, which they regard as older than the Astoria shale. See Am. Philos. Soc. Proc., vol. 52, pp. 580, 599, 1913.

2 Diller, J. S., U. S. Geol. Survey Seventeenth Ann. Rept., pt. 1, pp. 476-477, 1896. 
5315. Loose concretions on river bank in the lower part of Astoria:

Pseudamusium peckhami Gabb.

Prọpeamusium n. sp.

Crenella n. sp.?

Phacoides cf. acutiliratus Conrad.

5316. North side of Smith Point, Astoria:

\section{Natica sp.}

Utriculus sp.

Haminea petrosa Conrad.

Yoldia sp.

Malletia sp.
Solemya ventricosa Conrad.

? Saxidomus (fragment).

Fusinus sp.

Hemithyris astoriana Dall.

Pecten cf. vancouverensis Whiteaves.

Psephidea sp.

Hemithyris astoriana Dall.

Fish bones.

5317. Opposite 766 Irving $\Lambda$ venue, Astoria:

Pseudamusium randolphi Dall.

Pseudamusium peckhami.

Pseudamusium vancouverensis?

Serripes? sp.

Macoma like sabulosa Spgl.
Natica oregonensis Conrad; young specimen.

Chrysodomus sp.?

Hemithyris astoriana Dall.

531.8. Northwest corner of Tenth Street and Harrison Avenue, Astoria:

Hemithyris astoriana.

Solemya ventricosa Conrad.

Acila sp.

Nucula sp.

Malletia sp.

Pseudamusium randolphi?

Pseudamusium peckhami.
Phacoides acutilineatus Conrad. Thracia trapezoides Conrad.

Haminea petrosa Conrad.

Fusinus sp.

Natica oregona Conrad.

Dentalium petricola Dall?

Foraminifera.

5319. One block of old high school on Harrison Avenue, at the northwest corner of Eighth Street, Astoria:

Pseudamusium peckhami Gabb.

Propeamusium n. sp.

Thyasira bisecta? Conrad.
Solemya ventricosa Conrad.

Fusinus sp.

Dentalium sp.

5320. Opposite 1774 Franklin Street, Astoria:

\section{Nucula, 2 sp.}

Haminea sp.

Crab claw.

5321. Irving Avenue, in hill above sawmill, Astoria:

\section{Leda sp.}

Pseudamusium randolphi Dall.

Phacoides acutilineatus Conrad.

Natica oregona Conrad.

5322. Irving Avenue and Thirty-fourth Street, Astoria:

Hemithyris astoriana Dall.

Pseudamusium randolphi Dall.

5323. Irving Avenue near Thirty-seventh Street, Astoria:

Propeamusium n. sp.

Leda sp.

Acila conradi Meek.

Limopsis niceus Conrad.
Phacoides acutilineatus Conrad.

Natica oregona.

Pachypoma sp.?

5324. One mile east of John Day station on the Astoria \& Columbia River Railroarl, which is about $5 \frac{1}{2}$ miles east of A storia:

Pseudamusium peckhami. 
5325. Six telegraph poles east of milepost 92 on the Astoria \& Columbia River Railroad, which is about $8 \frac{1}{2}$ miles east of Astoria by rail:

Phacoides acutilineatus Conrad.

Pseudamusium peckhami.
Macoma sp.

Foraminifera.

5326. Eleven telegraph poles east of Svensen, which is $9 \frac{1}{2}$ miles east of Astoria; sec. 14, Clatsop County:

Venericardia $\cdot \mathrm{sp}$.

Pseudamusium peckhami.

Leda (acuta Conrad?).

5327: West end of tunnel at Fort Columbia, Wash.:

Yoldia? sp.

Propeamusium sp.

Fish scale.

5328. On the Nehalem dirt road south of Clatskanie, about 4,860 feet from Commercial Hotel, which is in the center of the town:

Tellina sp.

Macoma sp.

Solen cf. curtus Conrad.

Leda cf. taphria Dall.
Paradione sp.

Thracia trapezoides Conrad?

Indeterminate gastropod.

5329. On the Nehalem road about 14,781. feet south of the post office at Clatskanie; sec. 24 ?, T. 7 N., R. 5 W.:

Dentalium, $2 \mathrm{sp}$.

Natica.

Fusinus? sp.

Thais sp.?

Pleurotoma sp.

Odostomia sp.

Trichotropis? sp.
Dolium? sp.

Acila sp.

Mytilus sp.

Snlen.

Tellina.

Macoma sp.

Venerid bivalve.

5330. Two miles east of Westport on bluff; SE.

Internal casts in soft shale.

Bela?

Leda.

Psephidia.

Sigaretus.

5331. Shale outcrop on wagon road by Astoria \& Columbia River Railroad, $4 \frac{1}{2}$ miles west of Marshland and two telegraph poles west of milepost 68 ; SW. $\frac{1}{4}$ sec. 4 , T. 7 N., R. 5 W.:

Leda.

Acila.

Yoldia?

Solen cf. curtus Conrad.

Macoma.

Periploma?

Entodesma?

Cylichna?

. Dentalium sp.

5332. On Portland-Astoria wagon road 2 miles out on Youngs River, exposure at bridge; NW. 1 sec. 21, T. 8 N., R. 9 W.:

Deliquescent shale.

Pseudamusium peckhami.

Pseudamusium randolphi? Dall.

Acila sp.

5333. In conglomerate on Clatskanie-Nehalem road 1 miles southwest of Clatskanie; sec. 18?, T. 7 N., R. 4 W.:

\section{Natica or Euspira sp. \\ Cypræa n. sp. \\ Fusinus? \\ Margarites? \\ Patinopecten (young). \\ Acila sp. \\ Yoldia or Malletia ep.}

Arca (Yo.).

Solen cf. curtus Conrad.

Tellina.

Angulus sp.

Semele? sp.

Mactra ep. 
5334. 4,950 feet from Clatskanie on road to Mist; sec. 18, 'T: 7 N., R. 4 W.:

Rotten sandy shale with poor casts
of bivalves.
Nucula.
Yoldia?

Macoma.

Mactra.

Naticoid gastropod.

5335. In baked-clay bed near Zeinson's logging road 1 mile east of Clatskanie:
Lepton.
Angulus indet. gastropod.

5336. Ocean bluff near Haystack Rock, 1 mile south of Elk Creek on Cannon beach; SW. $\frac{1}{4}$ sec. 30 , T. 5 N., R. 10 W.:

Leda cf. Taphria.

Yoldia?

Macoma?

5337. One-half mile toward seaside from Elk Creek Hotel; altitude, 120 feet; NW. $\frac{1}{4}$ sec. 20 , T. 5 N., R. 10 W.:

Unrecognizable prints of bivalves.

5338. Near summit on seaside, Elk Creek road; SW. $\frac{1}{4}$ sec. 17, T. 5 N., R. 10 W.:

Unrecognizable prints of hivalves, one.perhaps a Pseudamusium.

5339. Smith Point, Astoria, bank 50 feet above Columbia River; SW. $\frac{1}{4}$ sec. 7, T. 8 N., R. 9 W.:

Dentalium sp.

Haminea cf. petrosa Conrad. Natica?
Leda cf. acuta Conrad.

Pseudamusium (peckhami?).

5340. Smith Point on road to Youngs River; SW. $\frac{1}{1}$ sec. 7, T. 8 N., R. 9 W.:

Fragments of naticoid and trochoid gastropods.

-5378. Opposite 382 Alameda Avenue, Astoria; SW. $\frac{1}{4}$ sec. 7, T. 8 N., R. 9 W.:

Propeamusium, 2 sp., both probably new, and fragments of other undeterminable bivalves.

5379. Sixth and Duane streets, Astoria, in rear of southwest corner house; altitude, 40 feet:

Solemya ventricosa Conrad.

Yoldia sp. fragm.

Propeamusium n. sp.

Agriodesma? sp. indet.
Panopea estrellana Conrad. Hemithyris astoriana Dall. Laqueus cf: jeffreysi Dall. Fragments of Asterites.

5380. Commercial Street, Astoria, road cut 2,650 feet west of Sixth Street, in dark gray shale:

Casts of Foraminifera too poor to determine. Oligocene?

5381. From a cut on Union Pacific Railroad on the west side of Chehalis River, Lewis County, Wash.; Oligocene:

Aturia cf. angustata Conrad.

Prints of Dentalium and Nuculasp. indet.

5382. Leahy's ranch on north fork of Clatskanie Creek, Creek Bluffs; sec. 18, T. 7 N., R. 8 W,:

Propeamusium n. sp.

Pseudamusium peckhami Gabb.

5383. Olney-Jewel county road, $6 \frac{1}{2}$ miles east of Olney, north fork of Clatskanie Creek; NW. $\frac{1}{4}$ sec. 28 , T. 7 N., R. 8 W.:

Nucula sp.

Patimopecten sp. fragm. 
5384. One and one-half miles below Lukkarila ranch, on Nehalem River, in sandstone overlying basalt; NW. $\frac{1}{4}$ sec. 19, T. 4 N., R. 7 W.:

Unidentifiable fragments of Pecten and Ostrea.

5385. Larsen's ranch in bluff of Nehalem River; SE. $\frac{1}{4}$ sec. 29, T. 5 N., R. 7 W.:

Very poor prints of Pecten, Dentalium, and Pseudamusium, probably peckhami.

5386: Seven miles east of Jewel on road to Mist, near Nehalem River; NE. $\frac{1}{4}$ sec. 33 , T. 6 N., R. 6 W.:

Very poor prints of Saxicava sp.? and Pseudamusium; badly crushed.

5387. West of Vesper and 10 miles east of Jewel on Nehalem River, bluff near county road; Oligocene:

Fusinus oregonensis Conrad.

Natica?

Bela?

Dentalium sp. indet.

Nucula.

Pseudamusium (peckhami?).

5388. County road to Mist, about 1,500 feet southeast of Vesper in road cut above Nehalem River;'SE. $\frac{1}{4}$ sec. 24 , T. 6 N., R. 6 W.:

Obscure print of Pseudamusium?

5389. One and one-fourth miles northeast of Fishhawk Creek on county road up Nehalem River, in massive clay; SE. $\frac{1}{4}$ sec. 8 , T. 6 N., R. 5 W.; Oligocene?:

Fusinus oregonensis Conrad.

Natica sp.

Dentalium sp.

Acila conradi Meek.
Leda sp.

Macoma sp.

Marcia cf. oregonensis Conrad.

5390. Clay bluff one-fourth mile southeast of Mist, on Nehalem River:

Same as 5389 with addition of numerous prints of Foraminifera.

5391. In clay 3 miles east of Mist, on Nehalem River bluff; SE. $\frac{1}{4}$ sec. 2, T. 6 N., R. 4 W.:

Similar assembly to 5389 without the Fusinus and Acila and with the addition of Pleurotoma sp.?

5392. Nehalem River, 8 miles above Mist, Columbia County; sec. 11, T. 5 N., R. 4 W.; Oligocene?:

Solen cf. curtus Conrad.

Glycymeris sp. indet.

Marcia cf. oregonensis Conrad.

Macoma sp.

Thracia sp.

Fusinus fragments; badly preserved.

5393. On river bed in blue limestone, 9 miles up Nehalem River from Mist; SE. sec. 14 , T. 5 N., R. 4 W.; Miocene:

Sisisula cf. precursor Dall.

Acila conradi Meek.

Leda.

Tellina.

Macoma sp.

Cryptoma oregonensis Dall.

5394. Pittsburg road cut, Columbia County; NW. 1 sec. 23 , T. 5 N., R. 4 W.; Eocene:

Fusinus cf. oregonensis Conrad.

Nassa n. sp.

Bela? sp.

Margarites? sp.

Molopophorus cf. gabbi Dall.

Acila shumardi Dall.
Leda sp.

Yoldia sp.

Solen sp.

Macoma sp.?

Paradione sp. 
5395. Crane's ranch, Tillamook County, $6 \frac{1}{4}$ miles above Garibaldi on Miami River; SE. $\frac{1}{4}$ sec. 35 , T. 2 N., R. 10 W.:

Very remarkable cast of large limpet, Patella or Acruæa n. sp.

5396. Entrance of Wilson River canyon, 5 miles east of Tillamook; SW. $\frac{1}{4}$ sec. 23, T. 1 S., R. 9. W.:

Acila?

Pecten?
Indeterminate bivalve fragments and cast of Echinus spine.

5397. Clay pit one-half mile above Willamina, Yamhill County; SE. $\frac{1}{4}$ sec. 36 , T. 15 S., R. 7 W.'

Acila.

Yoldia.

Cardium?

Margarites? sp. indet.

5398. On the beach about 4,800 feet northeast of the general store and post office of Knappton, Wash.; Miocene:

Dentalium conradi Dall.

Margarites?

Lima n. sp.

5399. About 10,440 feet along the beach or nearly 2 miles east of the general store and post office, Knappton, Wash; Miocene:

Acila conradi Meek.

Solemya ventricosa Conrad.

Macoma sabulosa Spgl.

Phacoides acutilineatus Conrad.

Thyasira bisecta Conrad.

Cryptomya oregonensis Dall.

5400. Near Grays Point, 11,520 feet along the beach or a little over 2 miles east of the post officeand general store of Knappton Lumber Co., Knappton, Wash.; Miocene:

Same as 5399 with addition of Dentalium conradi Dall and Eudolium petrosum Conrad.

5401. Two hundred yards west of the general store and post office of the Knappton Lumber Co., at Knappton, Wash., just back of the dining hall; Miocene:

Thyasira bisecta Conrad.

Phacoides acutilineatus Conrad.

5402. On a log at the foot of a shale formation about 4,800 feet northeast of the general store and post office of the Knappton Lumber Co., Knappton, Wash.:

Endolium petrosum Conrad.

5403. Commercial Street, at the southwest corner of Sixth Street, Astoria; Miocene:

Fusinus oregonensis Conrad.

Lunatia sp.

Dentalium petricola Dall.

Dentalium conradi Dall.

Phacoides acutilineatus Conrad.
Venericardia sp.

Macoma sp.

Arca sp.

Platinopecten propatulus Conrad.

5404. Southwest corner of Seventh and Exchange streets, Astoria:

Pseudamusium sp.

Clementia? n. sp.

5405. Irving Avenue west of Thirteenth Street, Astoria; Oligocene?:

Fusinus sp. indet.

Macoma cf. balthica L.

Turcicula cf. washingtoniana Dall. 
5406. A. M. Home's ranch, 3 miles south of McCoy, Polk County, about 400 yards southwest of the house; E. $\frac{1}{2} \mathrm{SW} . \frac{1}{\mathrm{sec}}$. 32 , T. 6 S., R. 4 W.; lower Miocene:

Fusinus oregonensis Conrad.

Thais sp.

Lunatia sp.

Trochita cf. radians Lamarck.
Dentalium couradi Dall.

Acila conradi Meek.

Saxidomus sp.?

Spisula ? sp.

5407. A. M. Home's ranch, 3 miles south of McCoy, Polk County, station 25 of Polk County; E. $\frac{1}{3}$ NW. $\frac{1}{4}$ sec. 5, T. 7.S., R. 4 W.:

Molopophorus cf. gabbi Dall.

Litorina sp. cf. gigantea Middendorf.

Lunatia sp.
Trochita cf. radians Lamarck.

Diplodonta cf. parilis Conrad.

Chione sp.

Macoma sp.

5408. A. M. Home's ranch, 3 miles south of McCoy, Polk County; E. $\frac{1}{2}$ NW. $t$ sec. 5 , T. 7 S., R. 4 W.:

\begin{tabular}{l|l} 
Mactra cf. delumbis Conrad. & Trochita cf. radians Lamarck. \\
Chione sp.? & Neverita cf. inezana Conrad. \\
Diplodonta cf. parilis Conrad. & Lacuna n. sp. \\
Macrocallista sp. &
\end{tabular}

5409. A. M. Home's ranch, 3 miles south of McCoy, Polk County, station 37 of Polk County; E. $\frac{1}{2}$ NW. $\frac{1}{4}$ sec. 5, T. 7 S., R. 4 W.:

Same as 5408, with Donax n. sp., Scala sp., and Bela? sp.

5410. Six miles west of Newberg, on Mrs. Helen Follette's farm in Yamhill County;

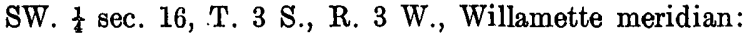

Solen curtus Conrad.

Dentalium petricola Dall.

Cardium sp. indet.

5411. Four and one-half miles northeast of North Yamhill, elevation 500 feet (approximate); sec. 25 , T. 2 S., R. 4 W., Willamette meridian.

Indeterminate gastropod.

Paradione sp.; very imperfect.

5412. Clay pit of the Pacific Face Brick Co., one-half mile west of Willamina post office, Yamhill County:

Indeterminate crushed bivalve.

5422. South side of Kellys Butte, bank of Willamette, one-half mile northwest of Springfield, Lane County:

Spisula albaria Conrad.

Thracia condoni Dall.

Diplodonta parilis Conrad.

Phacoides acutilineatus Conrad.

Solen curtus Conrad.

Macoma sp.
Chione sp.

Cardium? coosensis Dall.

Natica sp.

Crepidula ungana Dall.

Fragments of a crab.

5424. Judkins Point (west side), Eugene:

Fusinus oregonensis Conrad.

Chrysodomus sp.

Natica sp.

Spisula albaria Conrad.

Thyasira bisecta Conrad.

Phacoides acutilineatus Conrad.

Fragments of Macoma, Angulus, Schizothoerus and perhaps Thracia trapezoidea Conrad.

5425a. College Hill, Eugene, south end of Oregon Avenue:

Fusinus oregonensis Conrad? fragments.

$47196^{\circ}-$ Bull. $590-14-3$ 
5425b. West side of College Hill, Eugene:

Arctoscala condoni Dall.

Crepidula ungana Dall?

Pyrula modesta Conrad?

Fusinus oregonensis Conrad.

Dentalium n. sp.

Yoldia condoni Dall.

Spisula albaria Conrad.

Venus parapodema Dall.
Sanguinolaria $\mathrm{n}$. sp.

Diplodonta parilis Conrad.

Solen n. sp.

Pteria sp.

Chione? sp.

Fragments of Neverita.

Shark's tooth, probably of the genus Lamna.

5425c. Fossils from well on east side of College Hill; 1 mile south of Eugene:
Mytilus n. sp.
Modiolús n. sp.
Spisula albaria Conrad.
Marcia oregonensis Conrad.

5425d. Old quarry on south slope of College Hill, Eugene:

Thais, near decenicostata Middendorf.

Trochita inornata Gabb.

Crepidula ungana Dall.

5425e. South slope of College Hill, Eugene. (No list.)

5426. South of Monroe; Eocene:

Pyrula tricarinata Conrad.

Glycymeris sp.

Solen sp.

Mœrella sp.?

5427. Fairmount quarry, Eugene:

Poor casts of Marcia oregonensis Conrad.

Spisula albaria Conrad.
Ilyanassa sp.?

Paradione sp.

Spisula albaria Conrad.

5428. Casts from west side of Petersons (?) Butte, 5 miles southwest of Lebanon, Linn County:

Spisula albaria Conrad.

Marcia oregonensis Conrad.

Venericardia castor Dall.

Cardium cf. ciliatum Fabricius.
Teredo-bored wood.

Casts of small indeterminate bivalves.

Sanguinolaria n. sp.

Mulinia cf. oregonensis Dall.

Chione and Thracia sp.

5429. Railroad cut one-fourth mile west of Springfield Junction (not Springfield), 2 miles east of Eugene:

Internal casts of (probably) Natica oregonensis Conrad and Neverita inezana Conrad.

5430. Bluffs at Springfield Junction (not Springfield), Lane County:

Natica oregonensis Conrad.

Neverita sp.

Fusinus oregonensis Conrad.

Dentalium n. sp.

Actæon n. sp.

Ilyanassa $\mathrm{n}$. sp.

Leda cf. pygmæa Fabricius.
Macoma and Solen sp.

Neverita.

Fusinus and Crepidula sp.

5432. North and west of Monroe:

Trochita inornata Gabb.

Bittium sp.

Acila conradi Meek.

Diplodonta parilis Conrad.

Lima n. sp.

Solen n. sp.

Venus parapodema Dall.

Cardium coosensis? Dall.

Astarte and Semele sp., traces. 
5433. Gully below coal mine on H. C. Owen's farm, 10 miles west of Eugene:

Venericardia castor Dall.

Angulus aragonia Dall.

Crassatellites sp.?

Macoma sp.
Cardium sp.

Trochita inornata Gabb.

Bittium? sp.

Pecten sp.

5434. Hemenway's ranch, north of Goshen, Lane County:

Spisula albaria Conrad.

Marcia oregonensis Conrad.
Tellina aragonia Dall.

Cardium and Macoma sp.

5435. River bluff (lower part of section), Springfield (not Springfield Junction; see 5430):

Marcia oregonensis Conrad.

Leda whitmani Dall.

Spisula albaria Conrad.

Acila conradi Meek.

Solen curtus Conrad.

Thy'asira? sp.
Paradione? sp.

Trochita inornata Gabb.

Fusinus oregonensis Conrad.

Bittium sp.

Crepidula cf. ungana Dall.

5436. Scarborough place, south of Fairmont, Lane County:

Natica oregonensis Conrad.

Crepidula sp.
Cerithium sp.

Diplodonta parilis Conrad.

5437. Frank Dunn's farm south of Masonic Cemetery, 2 miles south of Eugene:

Crepidula ungana Dall.

Natica oregonensis Conrad.

Neverita sp.

Fusinus oregonensis Conrad.

Yoldia oregona Shumard.

Spisula albaria Conrad.

Diplodonta parilis Conrad.
Thracia trapezoidea Conrad.

Tellina eugenia Dall.

Sanguinolaria $\mathbf{n}$. sp.

Solen n. sp.

Modiolus.

Chione and Cardium sp.

5438. South side of Kellys Butte, Springfield:

Leda sp.

Sanguinolaria n. sp.

Diplodonta parilis Conrad.

Tellina aragonia Dall.

Solen n. sp.
Spisula albaria Conrad.

Macoma sp.

Cardium cf. coosensis Dall.

Epitonium? sp.

Crepidula cf. ungana Dall.

5441. Quarry 1 mile west of Blachly post office, Lane County:

Diplodonta parilis Conrad.

5445. Vauduyn Place, 1 mile east-northeast of Coburn; Miocene:

Crepidula ungana Dall.

Venus parapodema Dall.
Spisula cf. albaria Conrad.

Solen n. sp.

5446. River bluff (upper part of section), Springfield:

Arctoscala condoni Dall.

Venus parapodema Dall.

Thracia trapezoidea Conrad.

Solen curtus Conrad.

5447. Scotts Mills, Marion County:

Crushed casts of Mactra.

Glycymeris semele.

Venericardia.

Tellina aragonia Dall.
Paradione sp.?

Lima sp.

Xylotrya sp.

Diplodonta parilis.

Neverita.

Ilyanassa? 
5448: Richardsons Butte, west of Irving, Lane County; several thousand feet below Eugene Miocene and far above Venericardia beds; Eocene:

Turritella near inezana Conrad.

Fusinus sp.

Scala sp.

Acila shumardi Dall.

A radiate Mytilus.
Leda and Macoma sp.

Thracia cf. dilleri Dall.

Clementia sp. fragment.

Echinoid fragment.

5450. Basket Point, Umpqua River, 12 miles below mouth of Callapooia River, Douglas County:

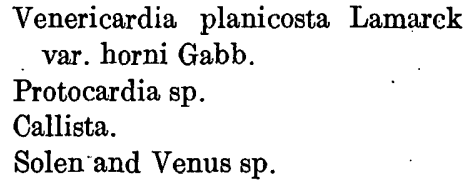

Teredo-bored wood.

Turritella inezana Conrad.

Pyrula tricarinata.

Ampullinopsis sp.

5451. Cut on Southern Pacific Railroad at Hemenway place, 1 mile south of Springfield; Eocene:

\begin{tabular}{l|ll} 
Badly crushed casts of Spisula & & Diplodontá parilis. \\
albaria. & Lyonsia? sp. \\
Venus parapodema. &.. &
\end{tabular}

FOSSIL PLANTS.

Mr. Knowlton's report on fossil plants collected near Eugene, Oreg., by the writer is given below:

This is a splendid collection of very perfectly preserved plants from shale at locality $3472,1 \frac{1}{2}$ miles northwest of Goshen, near Eugene, Oreg. In spite of its completeness, however, it has been difficult to locate satisfactorily. While I- was unpacking the material I thought I could recognize several species as common to the Pleistocene from Columbia River, but on taking them up for careful study it became evident at once that they were not identical with those plants. The forms presuméd to be identical belong to the genera Woodwardia and Sterculia, and although the same genera occur in the material from Eugene the species are not the same. In fact, out of a dozen or more species I am able to identify only Lastræa (Goniopteris) fischeri Heer, Populus zaddachi Heer, and Quercus simplex Newberry. The others, which are apparently new, belong to the genera Woodwardia, Ficus, Juglans, Cinnamomum, Laurus, Sterculia, and Rhus.

The three named species do not fix decisively the age of the collection. What I have called Populus zaddachi appears to be identical with this species from the auriferous gravels of California. The specimens of Lastræa (Goniopteris) fischeri are undoubtedly the same as the ones so determined from north of Ashland, Oreg., from beds ${ }^{1}$ of apparently the same age as the beds at Bridge Creek-that is, upper Eocene. Quercus simplex is a well-known species of Bridge Creek and is also upper Eocene.

These data are unsatisfactory, but as two of the species seem referable to the upper Eocene, and as none of the numerous leaves (with the exception of the Populus) in the collection appear identical with the various Miocene floras of the Pacific coast, I incline tentatively to regard this flora as upper Eocene.

1 Knowlton, F. H., Fossil flora of the John Day basin, Oreg.; U. S. Geol, Survey Bull. 204, p. 111, 1902. 


\section{COUNTY DESCRIPTIONS.}

Although most of the information gathered in the reconnaissance is from Clatsop County, it seems desirable to sketch the geology and to note the indications of oil in the other counties in western Oregon as far south as Lane County. Much of the material in this section was obtained in early purely scientific reconnaissances made prior to 1905. The writer has taken much material from a paper by Diller.' The fossil collections on which the determination of age of the rocks at the various localities depends were studied either by Dall, Arnold, or the writer, but mostly by Dall, to whom the writer is greatly indebted.

\section{CLATSOP COUNTY.}

Clatsop County, at the mouth of Columbia River, in the extreme northwest corner of the State, received more attention in 19.10 than any other because of the supposed oil prospects at Astoria.

GEOLOGY.

GENERAL FEATURES.

As far as can be determined from a reconnaissance of the few outcrops of deeply weathered rocks, Clatsop County is underlain by gently folded and much-faulted Tertiary shales, sandstones, and igneous rocks. The igneous rocks seem to bé present at every place, but their greater hardness and resistance to weathering is responsible for their more conspicuous outcrops.

The Astoria shale, previously described, probably occupies the greater part of the northeastern half of Clatsop County. Volcanic Eocene sedimentary rocks occupy most of the southern part of the county west of the summit of the Coast Range. Upper(?) Miocene sandstone outcrops at Clifton, 17 miles east of Astoria, and extends for an unknown distance southwestward thorugh the hills of T. $8 \mathrm{~N}$., R. $7 \mathrm{~W}$. In the associated tuffaceous rocks some fossil leaves were found.

COLUMBIA RIVER REgION.

Astoria to Tongue Point.-Massive and thin-bedded sandstones outcrop on the south side of Astoria hill near Youngs River and eastward along the waterworks road at intervals for several miles. This sandstone appears to be the same as that at Harrington Point and Smith Point, which lies above the Astoria shale. In places it is irregularly broken and faulted. The sandstone dips southeastward away from Astoria, and is succeeded on the south near Olney by a lower shale containing Miocene fossils (Astoria shale). There is probably a large fault south of the outcrop of this sandstone, but no further indications of it were seen. 
The structure of the Astoria shale within the city, where exposures are excellent, is rendered uncertain by landslides. Dips obtained in creeping rock or in displaced landslide blocks are of doubtful value, and it is generally hard to tell with certainty whether or not a given locality has been seriously affected by such movements. In a general way the entire hillside has the peculiar hummocky character of landslide topography so common in the Coast Range, and probably every exposure is to some extent affected by the downhill movement of the rock waste.

An east-west section indicates that a general north-south anticlinal structure passes through the city, which is strung out for 5 miles along the river.

Eastward from Smith Point, where Dall obtained many of his Miocene fossils, basalt appears at many places on the hill as far as John Day River. One hundred yards southeast of the basalt and above it topographically lies 4 feet of gray sandstone, which overlies 10 feet of shale, dips $40^{\circ}$ S., and has presumably been disturbed by the intrusion of the igneous rock. On the point basalt is exposed at low tide, and basaltic talus from the hillside may cover Dall's original locality, for no good fossils such as Dall describes could be found in 1910. The sandy shale with thin sandstone layers, poorly exposed on the wagon road, where it rounds the point, may belong to the fossiliferous sandy zone. 'At places for 12 blocks northeast of Smith Point a bluish-gray shale with many lime concretions is seen, dipping $5^{\circ}-15^{\circ} \mathrm{SE}$. The section is nearly parallel to the strike and probably does not represent more than 200 feet of strata. Eastward from the twelfth to the twentieth block there are only imperfect exposures of bluish-gray shale, apparently with fewer lime concretions, then about 100 feet of finely stratified blue shale with lime concretions and thin beds of hard sandy shale, which strike N. $30^{\circ} \mathrm{W}$. and dip $15^{\circ}-18^{\circ} \mathrm{SW}$. From Third Street to Fifth Street the general strike appears to be about N. $30^{\circ} \mathrm{W}$., dip $5^{\circ}-20^{\circ} \mathrm{SW}$.; from Fifth Street to Twelfth Street the strike is N. $60^{\circ}-65^{\circ} \mathrm{W}$., dip $5^{\circ}-12^{\circ} \mathrm{SW}$.; on Thirteenth Street the general strike is about N. $30^{\circ} \mathrm{W}$., dip $9^{\circ}-12^{\circ} \mathrm{SW}$. The southwest dip from Third Street to Thirteenth Street represents about 500 feet of shale if there are no intervening faults. The shale a ppears to pass under that exposed farther west. From Thirteenth Street to Twenty-seventh Street exposures are numerous, especially along Irving Avenue, where the strike is $\mathrm{N} .30^{\circ}-55^{\circ} \mathrm{W}$. and the dip $5^{\circ}-10^{\circ} \mathrm{SW}$. The section from Thirteenth Street to Twenty-seventh Street represents about 300 feet of clay shale, with a few concretionary horizons at irregular intervals. From Twenty-seventh Street to Thirty-third Street are very poor exposures of dark clay shale, resembling the rest and apparently dipping about $5^{\circ} \mathrm{SW}$. This indicates about 100 feet of shale. 
Between Thirty-third and Thirty-seventh streets, where no good exposures were seen, is the axis of an anticline or an exposed fault, probably the former. Farther east the dips are generally southeast, but the strata do not correspond perfectly with those on the west side of the anticline, having more sandy layers. No closed structure is indicated here, but rather an anticline which plunges southward. The strikes indicate an axis trending nearly north and south in harmony with the general structural lines, which are better determined north of the river. On the north side of the river no fold corresponding with this anticline was seen, the McGowan faulted anticline being too far west. The structure is more in line with some of the faults which cut the rocks between Knappton and Megler, but it is not safe to attempt correlation across the 6 miles of water that separates the opposing river bluffs on which the two sections were made.

The thickness of shole indicated by the section west of Thirty-third Street is 1,000 feet, which corresponds with the stratigraphic distance separating the Aturia zone from the massive sandstone at Huntington Point, in the section on the north side of the river. The correctness of this estimate depends on the absence of faults between Smith Point and Thirty-third Street, but it could be substantiated by the discovery of the Aturia zone at the foot of the hill anywhere between Thirtieth and Fortieth streets. The writer could find no one who knows exactly where Prof. Condon collected the specimens of Aturia that he found over 40 years ago " in loose concretions near the water level" in Astoria. " The enthusiastic amateurs of Astoria, who assisted the writer in his work, can render a useful and interesting service by relocating the long-lost Aturia zone in Astoria. This beautiful fossil may be recognized by its general resemblance to the pearly nautilus and should be sought in the eastern part of the city, near the axis of the anticline just described.

Little advice can be given as to drilling on this fold for oil. A well located at sea level on the axis near Thirty-third Street would penetrate probably 300 or 500 feet of shale and thin beds of soft sandstone before reaching the base of the Astoria shale, below which lie a few hundred feet of the harder sandstone and shale that form the top member of the Eocene. When the hard volcanic breccias of the latter formation are struck there will be little use in drilling deeper. If there is oil in the Astoria region it is as likely to be in this anticline as in any, but it should be remembered that the only oil sign on its flanks is "dead" or nonmigratory oil adsorbed on the clay particles of the shale, and that the porous sandstone dikes, which are thought to descend to the underlying sandstones, contain neither oil nor oil residues. These crosscutting sandstone dikes probably would contain traces of oil if there were any large deposits underneath them.

1 Labels on specimens in the Condon Museum, Univ. Oregon, Eugene. 
The east flank of the anticline is somewhat steeper than the west flank. Between Thirty-seventh and Fortieth streets the dip is $16^{\circ}-18^{\circ} \mathrm{SE}$. and the strike about N. $45^{\circ} \mathrm{E}$. Seven blocks farther east the dip decreases to about $10^{\circ} \mathrm{SE}$. The shale on the east side is similar to that on the west side of the anticline. The data given indicate about 700 feet of shale, assuming no appreciable faults.

The next good exposure is the excavation at the brick plant, 13 blocks east of Fortieth Street, where the strike is N. $60^{\circ} \mathrm{E}$. and the dip $22^{\circ} \mathrm{SE}$. The shale here looks somewhat different from most of the Astoria shale seen in the city and may be another formation faulted in. It contains no fossils nor concretions and is very poorly adapted to brickmaking, as shown by the product obtained. Above the lowest exposure there is at least 80 feet of shale, overlain on the east by 35 feet of very soft gray micaceous massive sandstone, which dips $35^{\circ}$ SE. This group of outcrops with high dips probably embraces 150 feet of strata, and there is also possibly 125 feet of unexposed strata west of it.

Four blocks east of the brickkiln 2 feet of soft sandstone and 15 feet of shale are exposed, both dipping southeast. A deep cut on the wagon road to John Day, on the hillside, 12 blocks east of the brickkiln and 3 blocks southwest of the Hammond lumber. mill, exposes 40 feet of bluish-gray shale containing many Miocene fossils. Some layers of the shale are sandy, and it contains numerous calcareous concretions, most of them less than 6 inches in diameter. The strike is $\mathrm{N} .65^{\circ} \mathrm{E}$. and the dip $10^{\circ} \mathrm{SE}$. One block southwest of the lumber mill is 50 feet of dark clay shale, dipping $10^{\circ} \mathrm{SE}$. and striking N. $60^{\circ} \mathrm{E}$. Back of the mill is 10 feet or more of fine hard sandstone, overlain by 40 or 50 feet of dark shale dipping $5^{\circ} \mathrm{SE}$.

This group of strata east of the brickkiln is too poorly exposed for good measurement, but with the data at hand a provisional estimate of 400 feet may be made.

Three blocks east of the Hammond mill the shale is overlain unconformably (?) by 3 feet of conglomerate and 12 feet of soft gray sandstone, the shale striking about N. $60^{\circ}$ E. and dipping $5^{\circ}-10^{\circ} \mathrm{SE}$. The next exposures eastward are thought to belong with the shale lying below the supposed unconformity.

Forty feet of dark concretionary shale is well exposed in two cuts two blocks northeast of the last exposure. The strike is N. $10^{\circ} \mathrm{E}$. and the $\operatorname{dip} 10^{\circ} \mathrm{E}$. The next good exposure is at Tongue Point, where a railroad cut exposes 20 feet of shale, overlain by 10 feet of sandstone, which in turn is capped by 30 feet of shale. The strike is N. $40^{\circ} \mathrm{E}$. and the dip $15^{\circ} \mathrm{SE}$., but the exposure is close to the igneous intrusion forming the point, and the intrusion may affect the inclination of the beds for a short distance. From such imperfect data a 
thickness of 150 feet of strata, probably mostly sandy shale with thin beds of sandstone, between Hammond mill and Tongue Point may be estimated.

The total thickness of beds on the east limb of the anticline to Tongue Point is therefore approximately 1,400 feet, or about 400 feet more than that on the west limb. The difference is thought to be due to the presence of additional strata, as suggested by the lithologic differences noted at the brick plant, and to the presence of several sandstones in the upper part of the section.

The conglomerate at Hammond mill seems to be the base of a nearly horizontal fresh-water formation, of which remnants have been seen at several localities. Perhaps the best exposures of this rock are at the sharp cape a mile east of Frankfort on Grays Bay, and 7 miles northeast of the locality just described. The sharp cape is a bluff of nearly horizontal coarse yellow sandstone about 70 feet thick that rests unconformably on inclined Astoria shale, which is exposed at two or three places at the foot of the bluff. The sandstone contains fragments of shale and shows faint traces of nearly horizontal bedding planes at the contact, above which it is cross-bedded or massive.

Dall ${ }^{1}$ regarded the sandstone near Tongue Point as equivalent to that at Smith Point, and the section measured in 1910 seems to confirm his view. Tongue Point is a basalt dike, 50 to 100 feet wide, trending northeast and southwest. A large block of sandstone and shale 40 feet in width, included in the basalt, may be seen from the river.

Tongue Point to Westport.-The rocks east of Tongue Point are thought to overlie the Astoria shale, at least as far as John Day River. The dips continue southeasterly, and the rock, where exposed, differs from the Astoria shale in containing more sand and in containing tuffaceous material. Immediately southeast of Tongue Point is a small island of straw-colored micaceous sandstone dipping $12^{\circ}$ SE., which contains some small black basaltic scoria or "volcanic cinders." One-half mile east of this are two outcrops of gray sandy shale interbedded with sandstone. In descending order at the second outcrop are 15 feet of bluish shale, 5 feet of light-gray sandstone, one-half foot of sandy shale, 8 feet of bluish-gray shale, 10 feet of soft gray medium-grained sandstone, and 1 foot of shale. The strike is N. $65^{\circ}-70^{\circ} \mathrm{E}$. and the dip about $10^{\circ} \mathrm{SE}$. This would indicate that between 300 and 400 feet of strata lie above the railway cut at Tongue Point and below the sandstone on the east bank of John Day River.

At the latter locality the railroad passes from a bridge over John Day River into a tunnel cut through a sharp point of yellow micaceous 
sandstone. The outcrop shows about 70 feet of sandstone measured vertically, which displays no bedding planes, the rock being almost perfectly massive, with only a suggestion of cross-bedding or jointing marked by brownish lines. Small round brown iron-cemented concretions are abundant. It is not certain whether this is a sandstone dike or an indurated mass of old dune sand, like that seen at the top of the hills farther south. It is probably not a part of the stratigraphic series here considered but is of later origin.

One-half mile east of the tunnel an exposure of 10 feet of sandstone, overlying a thin bed of shale and sand, strikes N. $80^{\circ}$ E. and dips $10^{\circ} \mathrm{SE}$. In the shale at this place a few specimens of $P$ seudamusium peckhami, a fossil common in Astoria shale, were obtained.

The next exposure eastward is at Fernhill, where there is 15 or 20 feet of gray shale, probably dipping gently southeast. 'A mile farther east there is a similar exposure; and a mile still farther east there is an exposure of 15 feet of foraminiferal and tuffaceous shale of chalky white color, overlying bluish-gray shale, which strikes nearly east and dips southeast. Most of the fossils at this locality are similar to those in the upper part of the Astoria shale. The rock, however, probably belongs to a higher formation, shale of this type being characteristic of higher horizons. The thickness of rock between Fernhill and this locality is probably less than 100 feet.

At Burnside station and eastward basaltic agglomerate overlain by Pleistocene sandy clay is exposed. The agglomerate is later than the sedimentary rocks. At Svensen station, 9.5 miles from Astoria, the railroad cuts expose bluish-gray clay, possibly decomposed shale. Beginning one-half mile farther east, back of the railroad, exposures of massive gray sandstones form bluffs reaching nearly to Knappa, where only fragmental basalt and Pleistocene red clay are exposed. The thickness of this sandstone is probably about 100 feet.

One mile east of Knappa an exposure of 15 feet of sandy carbonaceous clay containing thin coal partings strikes N. $50^{\circ}$ E. and dips $22^{\circ} \mathrm{SE}$. This outcrop is about 200 yards south of the railroad. The lack of intervening exposures makes it impossible to tell the stratigraphic position of the carbonaceous shale. Similar coaly rock is known both above and below the Astoria shale.

Northeastward along the railroad no other exposures are found for about 5 miles, to a cut three-fourths of a mile east of Aldrich Point, where there is a very poor outcrop of sandy shale. One mile farther southeast better outcrops of sandy shale and soft sandstone appear, and extend for 2 miles to Clifton, all dipping $5^{\circ}-37^{\circ} \mathrm{SW}$., the higher dips being local. This section represents about 200 feet of strata, in which gray sandy shale predominates, with thin beds of gray clay shale and a few beds of soft white micaceous sandstone 1 to 10 feet thick. A few fossil leaves were found in the sandstone, 
and some thin beds of coal are reported to outcrop on the same hillside. At Clifton 100 feet of sandy tuffaceous shale underlies the rocks noted above.

There is, therefore, over 300 feet of a sandy fresh-water formation higher than the marine sandstone at the top of the Astoria shale. The age of this formation is not known and its total thickness is a matter of conjecture, because neither its top nor its bottom have been seen. Similar tuffaceous shale is most common in the upper division of the Miocene of northwestern Oregon.

The converging dips indicate that a syncline, probably trending nearly north and south and plunging southward, crosses the railroad between 1 and 2 miles northwest of Clifton.

Two miles southwest of Clifton a high cliff of columnar basalt is capped by 30 feet of yellow sand. The basalt has a very low inclination $\left(3^{\circ}-4^{\circ} \mathrm{NW}\right.$.), but it is not thought to pass under the fresh-water rocks just described, and its relation to these strata is not certain. On the north bank of the river the same basalt, which there makes Pillar Rock and the cliffs of the "Barbary coast," rests directly on the marine sandy shale and sandstone of Huntington Point, which is at the top of the Astoria shale. The fresh-water strata do not intervene between the marine rocks and the basalt, but not enough information could be obtained to determine whether their absence is due to erosion or nondeposition, or to the alternative possibility that the fresh-water formation overlies the basalt.

The fresh-water formation may be in part contemporaneous with the basalt, as suggested by the presence of basaltic scoria and tuff in the fresh-water strata and by the interbedding of basalt and sandstone farther east. This feature is common in the Miocene or later basalt of the Chehalis Valley, Wash., and farther south in Multnomah and Clackamas counties, Oreg.

At Bugby station, a few miles farther southeast, the following section of the bluff was made:

Section of bluff at Bugby station.

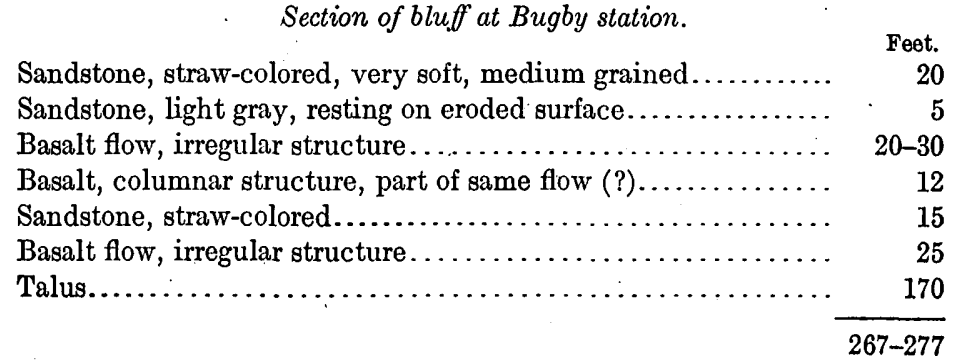

No outcrops other than basalt were seen between Bugby and Westport, near the eastern boundary of Clatsop County. At Westport there is a very poor exposure of light-colored clay, probably decom- 
posed shale. Diller ${ }^{1}$ reports that fossils of the Aturia zone (Oligocene) were collected by W. Q. Brown near Westport at a locality not definitely known. In Columbia County, 3 to 5 miles east of Westport, the writer made some meager collections of poorly preserved fossils, which may be Oligocene or lower Miocene. The rocks east of Westport are mostly shales, which dip westward at low angles for several miles.

If the Aturia zone occurs at Westport, it is an argument for the late Tertiary age of the basalt flows, which occur on the hills southwest of the station. The basalt rests on the sandstone at the top of the Astoria shale and on the fresh-water sediments overlying the sandstone; and if the Aturia zone occurs at Westport, the basalt must there rest on a horizon well down in the Astoria shale. These occurrences indicate that the rocks had been deformed and-deeply eroded previous to the basaltic eruptions.

YOUNGS RIVER BASIN.

Southeast of Astoria, on the road to Jewell, on Nehalem River, the section is probably similar to that occurring farther east along the railroad, but it is difficult or impossible to recognize the divisions of the strata because of meager outcrops. All the fossils found, so far as they could be determined, belong to one formation, the Astoria shale.

The sandstone at the top of the Astoria shale crosses the wagon road on the south side of the hill between the summit and Youngs Bay, dipping south. Shale also dipping south and containing the Astoria fauna lies immediately south of this, on the east end of Youngs Bay. This suggests a fault, of which no other evidence was found.

The shale outcrops imperfectly on the upper Wallusky and in places for $2 \frac{1}{2}$ miles near Olney. The dips and strikes in many places are not reliable, but the dips noted range generally from $4^{\circ}$ to $20^{\circ} \mathrm{SE}$. Fossils of the Astoria shale were found on East Fork of Clatskanie in the E. $\frac{1}{2}$ sec. 18 , T. 7 N., R. 8 W., also in secs. 8 and 21 , T. 8 N., R. 9 W. In sec. 21 the strike of the shale is $\mathrm{N} .40^{\circ} \mathrm{E}$. and the dip $7^{\circ} \mathrm{SE}$. In the same section, at the Evergreen dairy, an excavation shows 30 feet of soft yellow micaceous massive sandstone, the altitude and the stratigraphic position of which could not be determined. No other exposures of sedimentary rocks except clay and gravel, probably Pleistocene, and small outcrops of decomposed shale, too rotten to indicate the structure, were seen near the wagon road to Olney. In these outcrops the deposition of brown iron oxide along irregular curving lines, which cut the clay in all directions, is the only conspicuous feature. The bedding planes are lost. 
About a mile north of Olney about 3 feet of clay shale, dipping $15^{\circ}-20^{\circ} \mathrm{SE}$., is exposed by a road cut. Yellow micaceous shale, in places leached white by weathering, and all dipping southeast so far as could be determined, makes similar exposures along the wagon road to Olney. In the bottom of one road cut, about 4 feet of this rock is exposed, striking N. $65^{\circ}$ E. and dipping $25^{\circ}$ (?). SE.

On the creek bank three-fourths of a mile east of Olney there is a basalt dike 200 feet wide, which trends southward, forming the west border of dark clay shales dipping southeast to northeast at apparent angles of $15^{\circ}$ to $30^{\circ}$. On the Leahy ranch, $1 \frac{1}{2}$ miles east of Olney, there are dark clay shales with calcareous concretions resembling the upper part of the Astoria shale and containing the same kind of fossils. They strike N. $15^{\circ} \mathrm{W}$. and $\operatorname{dip} 10^{\circ}-15^{\circ} \mathrm{NE}$. One-half mile southeast of the Olney ranch the shale reappears, dipping $4^{\circ} \mathrm{NE}$.

The next exposures, which are 2 miles farther southeast, up the north fork of the Clatskanie, consist of basalt and sandstone, probably interstratified and representing beds above the Astoria shale like those seen near Clifton. In the sandy shale associated with the basalt in the NW. $\frac{1}{4}$ sec. 28, T. 7 N., R. 8 W., a Patinopecten and other fossils were found, all of them collected from the highest marine beds of the Astoria section, represented by the sandstones at Huntington Point. The sandstone is yellow, massive, fine grained, and micaceous. One large fragment of it, 50 feet across, was included in the basalt. A mile southeast, farther up the creek, indurated shale of the type characteristic of contact metamorphism in this region was seen. Many of the outcrops for the next 10 miles southeastward show the same metamorphism or so-called "baking" by igneous rock.

The basalt in the southern part of T. 7 N., R. 8 W., consists mainly of dikes and of sills intruded along bedding planes, but farther south some of the basalt may represent surface flows. The dikes are very numerous, probably to be counted by. hundreds, and some are large, 100 to 200 feet wide. Basalt composes most of the outcrops farther south in T. 6 N., Rs. 7 and 8 W., where there are also high volcanic necks of igneous rock, of which the most conspicuous are Saddle and Green mountains. The former (altitude 3,300 feet) is one of the highest points in northwestern Oregon.

Between the outcrops of basalt are imperfect exposures of mica clay shale, the age of which is not known. In sec. 34 , T. 7 N., R. $8 \mathrm{~W}$., where the wagon road ascends a low divide, about 20 feet of white baked clay shale may be seen, dipping $6^{\circ} \mathrm{E}$. This is underlain along the creek bottom by a basalt sill, which also dips eastward. On the southwest side of the divide is another outcrop of clay shale, which dips westward, possibly owing to the influence of adjacent igneous rocks. In the southern part of sec. 34 the basalt sill reappears along the main or south fork of the Clatskanie. Basalt and "baked" 
shale with erratic dips occupy the next 2 miles to the southeast. Between the bridge across the Clatskanie in sec. 12, T. 6 N., R. 8 W., and the summit of Sevenmile hill (altitude 1,550 feet) there are many surface exposures of rotten shale, in which no reliable dips were obtained. This hill itself, which is on the divide between Columbia and Nehalem rivers, is covered largely by clay soil, which is possibly derived from shale, but basalt dikes are seen on both sides of the summit. The falls on Little Fishhawk Creek are due to a large dike trending $\mathrm{N} .15^{\circ} \mathrm{E}$. A similar dike makes a magnificent cascade on Youngs River, and the surrounding hills are full of smaller falls produced in the same way.

On the hills immediately north of Youngs River Falls there are several poor outcrops of fresh-water sandstone, the dip of which is not certain but is probably southward at a low angle. This sandstone appears to overlie the Astoria shale. Several hundred feet of strata must be represented by the outcrops, but no good estimate of the thickness can be made. The age of the sandstone is unknown, but it is probably later than the Astoria shale.

NEHALEM RIVER BASIN.

Along Little Fishhawk Creek are many outcrops of dark clay shale, probably the Astoria shale. At the bridge in sec. 11, T. 5 N., R. 7 W., there is a good exposure of the shale," which here contains some calcareous layers and dips $3^{\circ} \mathrm{NW}$.

No fossils were found in this shale but the stratigraphy indicates that it represents a horizon low in the Astoria shale. The sandstone at the base of the shale is exposed on the hillsides east of the river and the Eocene beds outcrop below it near the mouth of Buster Creek. Somewhere in this vicinity ("at the fording nearly midway between Jewell and Mishawaka") Diller ${ }^{1}$ however made a good collection of fossils, which Dall pronounced "Eocene or lower Oligocene." Diller observed about 60 feet of concretionary shale containing some sandy tuffaceous layers, the strike of which is N. $22^{\circ} \mathrm{W}$. and the dip $15^{\circ}$ SW. This locality was not found in the reconnaissance of 1910.

Upstream along Nehalem River from Jewell the Astoria shale is seen at intervals for over 12 miles along the wagon road to Vesper, and beyond into Columbia County. This, however, does not mean that the shale has great thickness, for the distance is measured along the wagon road, which follows the great 2 and 3 mile bends of the winding narrow valley of the Nehalem. Moreover there appear to be minor plications of the strata and also one major anticline trending northeast through the west-central part of the section, to which it is oblique. The dips are low, ranging from $2^{\circ}$ to $15^{\circ}$. 
Fossils collected at three localities in this section, between Jewell and Vesper, are in accord with the foregoing statement, since they are referred with doubt to the Oligocene by Dall. The structure indicates that the rock at these localities is in the middle part of the Astoria shale. The localities are 6 miles below Vesper (5386), 1 mile northwest of Vesper (5387), and ono-half mile southeast of Vesper (5389), the fossils found being those most common in the Astoria shale.

This region east of Jewell and the adjacent part of Columbia County are worthy of detailed examination by oil men. No oil indications are known, but the gentle folds of the strata and the apparent absence of fractures indicate at least the probability of favorable structures. No faults nor dikes of basalt or sandstone were noted.

Up Nehalem River from Jewell northeastward to Vesper clay shale appears at short intervals for 2 miles along the wagon road to the ferry and bridge, where a landslide exposes 50 feet of dark micaceous sandy clay shale striking approximately N. $35^{\circ}$ E. and dipping $13^{\circ}$ SE. At the next exposures, 5 miles from Jewell, there is light-gray shale, which strikes N. $10^{\circ}$ E. and dips $28^{\circ}$ NW.; at a distance of 5.3 miles from Jewell there is a foot of shale, weathered white, which dips $22^{\circ} \mathrm{N}$. (?); at a distance of 6.4 miles, in the NE. $\frac{1}{4}$ sec. 33, T. 6 N., R. 7 W., there is gray fossiliferous micaceous Astoria shale, striking about N: $15^{\circ} \mathrm{E}$. and dipping $15^{\circ} \mathrm{NW}$, and the same rock extends for 7 miles to a point where the strike is N. $55^{\circ} \mathrm{W}$. (?) and the dip $11^{\circ}$ NE. (?); at a distance of 7.1 miles the same rock, striking N. $15^{\circ} \mathrm{E}$. and dipping $20^{\circ} \mathrm{SE}$., is overlain unconformably (?) by sandy micaceous shale, containing a hard layer with impressions of fossil reeds and dipping $4^{\circ} \mathrm{E}$.; at a distance of 8.1 miles there is 10 feet of shale dipping (?) $25^{\circ} \mathrm{NW}$. and containing the same fossil plants, but possibly belonging to a higher formation; at a distance of 10 miles there is a 20 -foot bluff of dark-gray clay shale, striking N. $25^{\circ}$ E. and dipping $8^{\circ} \mathrm{SE}$., containing limestone concretions and fossils (5387) of the Astoria shale; at a distance of 12 miles, or one-fourth mile southeast of Vesper, there is 15 feet of clay shale, with fossils (5388), striking $\mathrm{N} .75^{\circ} \mathrm{E}$. and dipping $5^{\circ} \mathrm{SE}$., the section continuing from this point into Columbia County.

The foregoing observations are clearly inadequate for an accurate determination of the structure, but taken in connection with observations made farther west and on Buster Creek, to the south, they suggest a small anticline near Jewell, a syncline between 2 and 5 miles northeast of Jewell, an anticline about 7 miles from Jewell (probably the major fold that brings up the Eocene beds on Buster Creek), a minor syncline less than a mile east of this, and a minor. anticline between 8 and 10 miles from Jewell. It should be remembered that observations like these, made along the wagon roads of 
northwestern Oregon, without detailed work through the forests on both sides, do not obtain all the data in the field, and that any conclusions drawn from them should be regarded as merely tentative and subject to revision when more complete data are at hand. The extent to which the structure is affected by faulting is unknown.

Micaceous clay shale is well exposed in low bluffs a mile south of Jewell, in the western part of sec. 13 , T. 5 N., R. 7 W. The strike is N. $30^{\circ}-45^{\circ}$ E. and the dip $8^{\circ}-14^{\circ}$ NW.

Immediately south of the locality last mentioned, near W. E. Herrick's house, is 20 feet of basaltic agglomerate, composed of tuff, scoria, and waterworn pebbles, which possibly belongs to the underlying Eocene, better exposed in the lower canyon of Nehalem River. The same rocks are exposed on Buster Creek above Herrick's ranch in secs. 26 and 25, T. 5 N., R. 7 W., where there is a blue basaltic breccia, cemented with pyritiferous calcite and interstratified with conglomerate, tuffaceous sandstone, and sandy shale. The conglomerate contains bowlders up to 2 feet in diameter. The exposures examined on this creek include less than 200 feet of variable strata, and this is only a small part of the entire formation.

Downstream from Grand Rapids along Nehalem River, in sec. 23, T. $5 \mathrm{~N}$., R. $7 \mathrm{~W}$, the Eocene occurs in ascending order broken by down-faulted blocks of the Astoria shale, the whole series dipping northwest or southwest as far as the mouth of Quartz Creek in sec. 9 , T. 4 N., R. 7 W., below which a syncline is indicated by northeast dips that continue for 6 miles down the canyon to the mouth of Sprucerun Creek, in sec. 24 , T. 4 N., R. 8 W. Somewhere in the canyon below Sprucerun Creek an anticline probably sets in, for southwest dips were observed in the same strata across the line, in northern Tillamook County.

About 50 feet of hard thin-bedded sandstone, occupying approximately the same stratigraphic position as that seen at the top of the Eocene at Megler, Wash., outcrops one-fourth mile west of Grand Rapids. It is separated from the basaltic agglomerate, on which it would normally rest, by a large dike (?) of basalt about 100 feet thick, trending northward and dipping eastward. Two hundred yards east of the "dike" is a mineral spring, with inflammable gas. (See p. 59.)

One mile west of Grand Rapids 20 feet of micaceous clay shale strikes N. $30^{\circ}$ E. and dips $10^{\circ} \mathrm{NW}$. The same rock with similar dip extends a mile down the canyon of the Nehalem, embracing a thickness of 350 feet. The central part contains numerous lime concretions. The shale reappears at distances of 3,4 , and 4.6 miles from Grand Rapids on the road to Elsie. At the 4-mile exposure, which is in the SE. $\frac{1}{4}$ sec. 29 , T. 5 N., R. 8 W., a 30-foot excavation shows laminated clay shale, with sandy layers containing a little mica and a 
few hard lime concretions. The few fossils obtained here (5385) are common in the Astoria shale. The next exposure, also shale, is at Pope's sulphur spring near Elsie, in the northwest corner of sec. 5, T. 4 N., R. 8 W.

Below Elsie, Humbug Creek flows over a coarse-grained basaltic rock to within one-fourth mile of Nehalem River. The canyon of the Nehalem, through T. 4 N., R. 7 W., is almost wholly in basalt, which is probably in contact with the Astoria shale near the northern margin of the township. In sec. 9, 20 feet of laminated dark and light colored clay shale rests on basalt and dips $14^{\circ} \mathrm{SW}$. In the NW. sec. 8 a similar outcrop dips $10^{\circ} \mathrm{NE}$. The relation of these outcrops to the basalt was not determined.

At the sharp loop of Nehalem River in the NW. $\frac{1}{4}$ sec. 7, T. 4 N., R. $7 \mathrm{~W}$., is a massive, coarse tuffaceous sandstone and conglomerate containing fragments of clay shale, basalt, and lime concretions mostly waterworn. Similar conglomerate occurs 2 miles farther south in the NW. $\frac{1}{4}$ sec. 19 , where it contains fossil oysters and pectens (5384), which could not be specifically determined. Basalt forms the walls of the canyon between these two places, except in the wider part at Lukkarila's ranch, in the SW. $\frac{1}{4}$ : sec. 7 , where about 700 feet of micaceous clay shale dips $28^{\circ}$ NE. and strikes N. $65^{\circ}$.W. The relation of the shale to the basalt was not determined. Gas escapes in noticeable quantity from the bed of the river near Mr. Lukkarila's house, through about 3 feet of gravel resting on micaceous clay shale. The canyon of the Nehalem was not examined below the point where the river leaves T. 4 N., R. 7 W.

These igneous and sedimentary rocks are probably Eocene, for they resemble the Eocene on the north bank of the Columbia opposite Astoria and farther south in Tillamook County. Diller ${ }^{1}$ collected fossils, probably of Eocene age, $2 \frac{1}{2}$ miles below the mouth of Humbug Creek, probably at the locality in the NW. $\frac{1}{4}$ sec. 19 mentioned in the last paragraph. He observed the tuffaceous sandstones, which contain in places conglomeratic portions with small pebbles, many of which are angular, and he reports that the igneous rocks continue down the Nehalem for 20 miles below Mishawaka. This would carry, them across the line into Tillamook County, where similar strata were seen.

SOUTHWESTERN CLATSOP COUNTY.

Owing to the absence of roads and the almost impenetrable brush little work was attempted in the southwest corner of the county, except along the seacoast. An inspection of the topography of that region from the summit of Onion Peak indicates that except in the low country of T. 4 N., R. 9 W., it contains many ridges and peaks

1 U. S. Geol. Survey Seventeenth Ann. Rept., pt. 1, p. 466, 1896.

$47196^{\circ}-$ Bull. $590-14$ - 4 
of igneous rock. The Astoria shale probably underlies much of this township, judging from the trend of the formation in adjoining territory, but the township was not examined.

A ridge marking the position of basalt dikes begins near the northwest corner of this township and runs. northwestward with gradually increasing altitude to Tillamook Head, one of the boldest promontories of the Oregon coast. Where the road from Seaside to Cannon Beach crosses this ridge the excavations reveal Astoria shale, with typical fossils, at least on the southern side. On the northern side, between parallel dikes of basalt, the shale is more sandy and whiter, resembling the shale interbedded with sandstones at horizons above the Astoria shale. Similar shale is exposed on the sea cliff north of the cape.

South of Tillamook Head on the north side of the basalt dike at Chapman Point, one-half mile from Elk Creek, baked shale was seen. Cannon Beach, a beautiful bit of coast line backed by high sandstone cliffs and facing a sea studded with volcanic rocks, begins at this point and extends 7 miles southward to Arch Cape. On the northern half of the beach the outcrops are poor and far apart and appear to represent horizons well up in the Astoria shale. Fossiliferous dark clay shale was seen dipping $8^{\circ} \mathrm{S}$. in a small cliff near Haystack Rock, a mile south of the mouth of Elk Creek (5336); and 2 miles farther south more shale was seen dipping $5^{\circ} \mathrm{NE}$., beneath a basalt sill. Along this part of the beach no other exposures were seen, except a few rocks, all of which are basalt, that rise out of the ocean.

A fine line of yellow sandstone cliffs begins a short distance south of the last exposure and extends through secs. 7 and 18. The sandstone is mostly coarse grained and massive, cross-bedded and pebbly in places. It is cut by many faults, dikes, and sills, from which it has acquired such an uncertain structure that in spite of the excellent exposure an accurate measurement of its thickness is impossible. There is over 200 feet of the rock in one fault block and the total thickness probably exceeds 400 feet.

At Silver Point two basalt dikes trend N. $65^{\circ}$ E. at the side of about 100 feet of sandstone laminated with thin streaks of black clay shale. South of this the fractured sandstone is well exposed and is cut by several large dikes, one of which has produced remarkably irregular twisting and bending of the strata in the cliff. About $1 \frac{1}{2}$ miles farther south, on the south side of Hug Point, a 60 -foot dike of basalt trending $\mathrm{N} .40^{\circ} \mathrm{E}$. is bordered on the north around the point by sedimentary rocks, mostly green pebbly sandstone, of which about 300 feet is exposed. The dip is $15^{\circ} \mathrm{NE}$. and the strike N. $40^{\circ}$ W. On the north side of Hug Point the intrusive basalt breccia is so intermingled with sandstone that in places it is hard to draw a line 
between the igneous and the sedimentary rocks. The rock is broken and contorted, with many small faults and intrusions.

Three-fourths of a mile south of Hug Point the same pebbly, yellowweathering sandstone dips in the opposite direction (strike N. $45^{\circ} \mathrm{W}$., $\operatorname{dip} 45^{\circ} \mathrm{SW}$.) and is cut by a 40 -foot dike of basalt trending northeast. Only 150 yards south the same beds strike N. $85^{\circ} \mathrm{E}$. and dip $40^{\circ} \mathrm{N}$., and are cut by a 10-foot dike of basalt at the north end of the exposure and by a sill of basalt 5 to 15 feet thick near the top of the bluff.

The sandstone on the southern half of Cannon Beach is thought to be part of the formation above the Astoria shale. Similar rock is exposed also at Youngs River Falls and on North Fork of Clatskanie River; in both places it is associated with much igneous rock.

At Arch Cape, at the south end of Cannon Beach, a large dike trends east and west. The top of the ridge is massive yellow sandstone, and similar sandstone is present immediately south of the cape.

Oligocene strata occur at Short Beach, south of Arch Cape, on the boundary of Clatsop and Tillamook counties. About 250 feet of thin sandstone and shale are exposed which correspond with the base of the Astoria shale as exposed a mile northeast of Megler, on the north side of the Columbia. Near the middle of Short Beach, Diller ${ }^{1}$ found fossiliferous concretions in dark shale, from which he obtained representatives of the fauna of the Aturia zone of the Astoria shale. Higher rocks are exposed at several places farther north.

\section{NORTHWESTERN CLATSOP COUNTY.}

Massive soft yellow sandstone, imperfectly consolidated, makes some low bluffs 10 to 30 feet high along the north side of Youngs Bay. This rock is horizontal, and rests unconformably on both the Astoria shale and the overlying Miocene sandstone. The lower part of it is well stratified in thick beds and appears to be an ordinary water-laid sandstone. It contains concretions and angular fragments of the Astoria shale, which probably rolled down from the steep hillside adjacent while it was being deposited. The upper part of the sandstone is wind-blown dune sand, with marked cross-bedding. The lower part is 10 to 20 feet thick, and the upper part is at least 50 and possibly 100 feet thick, if overlying isolated areas of similar rock belong to the same formation. This rock contains no fossils other than unrecognizable plant fragments, but its topographic relations indicate that it is either Pliocene or early Pleistocene, probably the latter.

Pliocene or early Pleistocene sandstone similar to that on Youngs Bay, consolidated in about the same degree, occurs at many places in the eastern part of the county and on the hills in the western 
part of Columbia County. It lies usually on the top of the flat hills (remnants of a former plain), which stand at altitudes of 200 to 400 feet. Along Columbia River similar sandstone caps the high basalt terrace near Clifton, Westport, and other localities. As the sands were deposited by wind their attitude has no bearing on the structure or deformation of the rocks, but they point back to a time when the region was not heavily forested, as it is to-day, and when the winds transported much sand over plains that are now dissected and heavily clothed with vegetation.

The northwest corner of the county west of Youngs River is entirely covered by Quaternary sand and silt, which conceal the outcrops of older formations. It is probable that the fresh-water sandstones above the Astoria shale occupy much of this region. The following section of a water well drilled at Fort Stevens furnishes a clue to the strata beneath that place. The top of the well is 16 feet above and the bottom 710 feet below sea level. No indication of oil or gas was noticed in drilling.

Log of water well at Fort Stevens, Oreg.

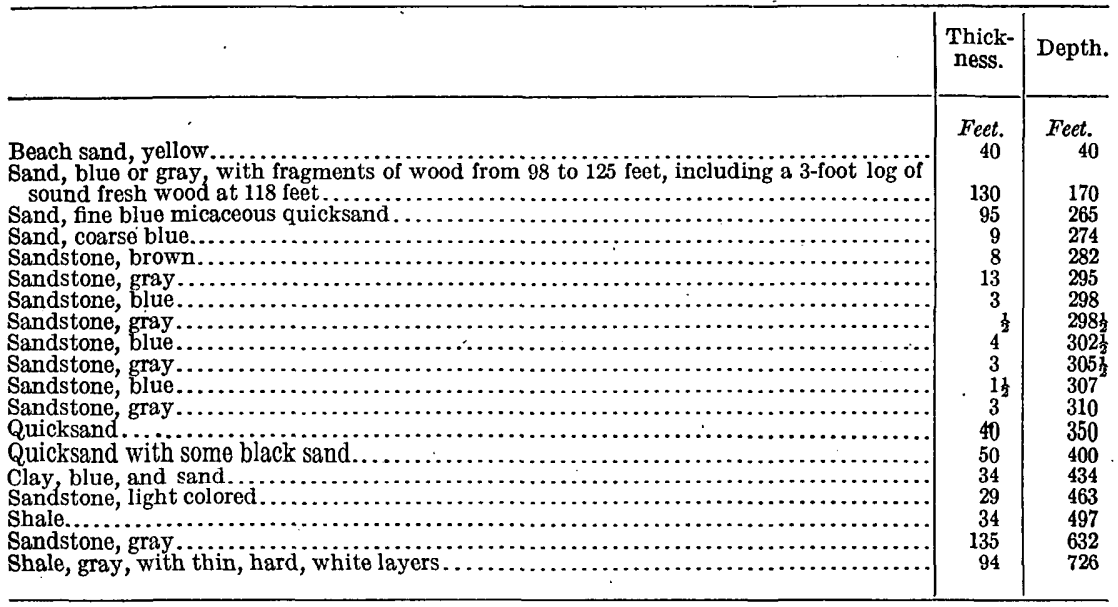

In this well it is interesting to note the presence of soft caving sand, called quicksand by the drillers, below hard consolidated sand which they call sandstone, probably correctly. The quicksand is said to have been forced up in the casing at times before it could be cased off. If the sandstones were overlain by shale, fissures in the shale would probably be filled by the underlying quicksand, producing sandstone dikes such as those that occur in the Astoria shale.

\section{INDICATIONS OF OIL.}

In Clatsop County oil indications are limited to minute traces, most of which are "dead" or nonmoving oil and residues, all in small quantities. The Astoria shale at many places will yield 
minute traces of oil by distillation, but this method drives out the dead oil which is adsorbed on the rock particles, and may create oil by the decomposition of organic matter. Distillation, therefore, is not a reliable indication of the presence of free oil in the pores and fissures of the rock. It is only free oil, largely capillary, that can be extracted from the rocks by oil wells. Extraction tests with benzole, ether, and other solvents of oils are probably more satisfactory, since these tests are known to give only traces of oil from rocks that yield a high percentage by distillation. Testing with solvents rarely gives any oil from the Astoria shale, even when the shale is pulverized for the test. It is probable that nearly all free capillary oil may be removed with solvents. Displacement by water gave a trace of oil from only one sample, which consisted of shale that had disintegrated into mud. Possibly the weathering and disintegration of the shale had changed the phase of the oil's existence from adsorptive to free capillary. Displacement of the oil by water when successful gives the most reliable proof of the presence of free oil in the rock pores. As the surface rocks of this region are generally saturated with circulating ground water that reaches the surface in the rainy season it is not unreasonable to think that the water has washed out all the free oil of the rock that can be removed by water displacement. For many oil rocks a good sense of smell furnishes the most delicate test, but in the presence of hydrogen sulphide and fetid odors it is not reliable.

The most nearly saturated oil rock found in the Astoria region is on Mr. Hawkins's ranch on Bear River, Wash., 11 miles northwest of Astoria: It may be reached by wagon road from Wallicut station on the Ilwaco Railroad. The oil-bearing rock is concretionary limestone, occurring mainly as slickensided balls in greatly fractured and deformed clay shale. The shale is exposed in a timbered ravine half a mile south of the ranch house in an excavation made by $\mathrm{Mr}$. Hawkins in prospecting for minerals. The concretionary rock is mostly light gray in color and dense in texture and gives little indication of the presence of oil, which was suspected only when $\mathrm{Mr}$. Hawkins discovered that the rock gave off flashes of flame when placed on hot coals. Some of the rock is cut by many little veinlets of unjointed lustrous black solid hydrocarbon which soften under gentle heat and are partly soluble in both ether and benzole, but oil was also obtained in the same locality from concretions that do not contain these veinlets. The veinlets are rarely more than 1 millimeter in diameter. The rock smells strongly of petroleum on fresh fracture. When heated in an open vessel gas is given off which takes fire and burns by flashes and the rock quickly changes in color from light gray to jet black. Some of the rock was pulverized and placed in a homemade retort made by Mr. W. E. Dement, of Astoria, and 
was heated over a wood fire. After considerable gas and water vapor had distilled over into the condenser bottle colorless oil began to appear, turning gradually through yellow to reddish yellow. It is improbable that this crude method secured all the oil in the rock, and as the heaviest parts of the oil probably remained in the rock no conclusion is warranted as to whether the base of the oil is mainly asphalt or paraffine. About 4 ounces of selected oil rock gave 0.8 cubic centimeter of reddish-yellow limpid oil, which probably represents a large part but not all of the oil that was in the rock at the beginning of the experiment. A sample tested by extraction with chloroform yielded only a few drops of yellow oil. Water displacement was not tried on these specimens.

A trace of oil was obtained from shale mud, collected from the excavation for the Elks Hall, at Exchange and Eleventh streets, Astoria. The disintegrated shale was dried, pulverized, and placed in boiling water. A few small drops of heavy oil appeared at the surface, each of which made a film having a central nucleus of soft black hydrocarbon, probably asphalt, surrounded by a thin iridescent oil-scum, filaments of which were drawn out when the water was stirred. With cold water no oil was obtained. An ounce of the same material was placed with chloroform in a closed bottle and left standing two days, with occasional shaking. After filtration and evaporation of the chloroform a drop of yellowish red oil remained with a little water.

Indications of oil in the Astoria shale is furnished also by concretions found at Tenth and Harrison streets and other localities. These traces are probably all "dead" oil, since they fail to respond to extraction tests with solvents. The indications consist of hydrocarbon stain near little joints. which cut the lighter-colored rock of the lime concretions. Such distribution can be due only to former migration of oil along the joints. One small lenticular veinlet of lustrous black hydrocarbon, about 3 millimeters thick, was found in the shale.

A large chunk of a dull black hydrocarbon, probably connected with oil, in its origin, was found in 1896 on the billside back of Knappton, Wash., opposite Astoria, by W. A. Barrells, manager of the Columbia Mills at Knappton. The specimen, which measures 6 by 12 by 16 inches, is now the property of $\mathrm{H}$. C. Harrison, of Astoria. It was found loose on the hillside, and although a few other smaller pieces. have since been found in the same vicinity the hydrocarbon has not been found in place and its geologic relations are not known. The rocks of the vicinity where visible are Astoria shale and intrusive basalt. The mineral is elastic, tough, dull black in color, with a slightly brownish, nearly black streak. Its structure is massive, without joints or bedding. It is a little too brittle to permit shaving with a knife, yet is so elastic that a hammer rebounds when struck 
against it. The mineral has been taken for cannel coal, oil shale, and asphaltum by various people familiar with these substances. Prof. Bradley, of the Oregon Agricultural College, examined a sample for Mr. Harrison and reported that it is probably carbonaceous shale approáching asphaltum in composition, containing much volatile matter and yielding a tarry product on distillation. It was thought by two geologists with extensive knowledge of coal that it might be cannel coal, but on subjecting it to a proximate analysis, about 95 per cent of it disappeared as "volatile," this being doubtless due to the ready combustion of the rock, which is easily lighted with a maich and burns with a yellow smoky flame. On being tested in the oil laboratory of the Geological Survey, it was found not to be soluble to an appreciable extent in benzole or ether.

The rock is probably a hydrocarbon, very old and altered by weathering. Careful prospecting on the hillside with pick and shovel might discover the fresh rock in place and determine its geologic relations. "The writer regards it as "dead" oil sign and as evidence of the former migration of oil at this place.

Traces of oil were obtained from the shale on the north shore of Youngs River, where the road from Astoria to Nehalem first strikes the river.

In weathered vesicular basalt a mile west of the preceding locality, near the north end of Youngs River wagon bridge, a few steam blebs were found to be filled with black, shiny, brittle hydrocarbon. The basalt is too poorly exposed to reveal its relations to the strata, but probably it is a dike. Similar hydrocarbon was observed in pores on the east margin of the large dike in the southwestern part of Ilwaco, Wash., near the shore of Columbia River. The pores filled with hydrocarbon are 1 millimeter to 3 millimeters in diameter.

No oil seeps were found in Clatsop County, although all the reported localities were examined and samples tested. No oil nor oil residue was found in sandstone. The sandstone dikes, from their porosity and great vertical range, were thought to be excellent places to look for oil, but careful search failed to reveal a single trace of any hydrocarbon.

\section{INDICATIONS OF GAS.}

SOURCES.

Inflammable gas may be detected at many places in Clatsop County, and across the river in the neighboring part of the State of Washington. The indications may be divided into two classes-(1) gas occurring in the Tertiary strata or under conditions that indicate that it comes out of underlying rock, and (2) marsh gas formed in the mud under either salt or fresh water. The first class alone indicates any probability of finding commercial quantities of gas in the rocks. 
MARSH GAS.

The second class, or gas formed in the superficial mud and muck of estuaries, rivers, lakes, and swamps, needs little consideration. It is present under practically every bit of water in the region that has a mud bottom and, rarely, a sand bottom. Fewer traces have been found in water that is salt at low tide than in water that is brackish or fresh at low tide, and the brackish waters of all the coastal streams show inflammable gas when the mud is stirred, usually in considerable quantity. On the open sea coast no indication of gas was noted beneath the salt water, but the bottom along this shore is wholly sand or rock. The writer did not find a single spot, out of probably a hundred tested, where the mud beneath brackish tidal waters did not yield marsh gas. Gas is also common in the mud under fresh water, but it is not present at all localities, and its quantity is notably less than under the slightly salty waters, except in one or two places (noted below) where its escape is sharply localized and probably marks the position of gas "seeps" from the underlying rock. There is a marked concentration of marsh-gas localities along the brackish water belt near the coast line, outside of which, in the higher fresh-water parts of the same streams, there is less gas in the mud and in many places none that can be detected by the ordinary crude methods available in the field. It is evident that for some reason marsh gas is produced more rapidly or in greater quantity in the mud under brackish water than in fresh water, though the relative quantities produced are not known. The reason for this difference must be sought through chemical or bacteriological studies.

The traces of gas found in the Astoria shale may have formed in the same way when the shale was mud and have remained in the rock pores until tapped. If such be the case there is no justification for considering the gas as an indication of oil, since no oil appears to be produced by the fermentation or decomposition that sets free marsh gas in the carbonaceous mud. Careful search at many localities failed to show any trace of oil with the gas bubbles, with the possible exception of the gas locality at Brown's dairy farm. (See p. 57.)

If the shale were laid down under conditions approaching those of mud deposition in the brackish-water estuaries of the Oregon coast to-day, and if the marsh gas entrapped in the pores were concentrated in the sandstone, a gas field could readily be formed. Of course, the reader will recognize enough "ifs" in this statement to invalidate it as a prediction of a gas field at any place. The statement, however, is very moderate, for the amount of gas produced in the mud in a few years is to be measured probably by hundreds of times the volume of the mud.

A rude measurement of this nature was attempted near Ilwaco, Wash., on the north shore of Baker Bay.' The mud, which is $2 \frac{1}{2}$ feet 
thick at the point tested, is black and slightly sandy from top to bottom; the top is loose and soft, but the lower foot is firmly packed and possibly should not be included in the calculation because it may not contribute to the ebullition of gas. The mud rests on hard rock, probably sandstone, as determined only by sounding with a crowbar. The outcrops on the shore are shale, sandstone, and basalt. A bucket was inverted under the water, in a depth of about 3 feet, and left anchored on the mud for one hour. At the end of that time it was found to contain 16 cubic inches (measured under atmospheric pressure at a temperature of about $60^{\circ} \mathrm{F}$.) of inflammable gas, probably mostly marsh gas. This gas was probably derived from about 4,050 cubic inches of mud, since the bucket covered an area of 135 square inches and the mud is $2 \frac{1}{2}$ feet deep. If the lower foot. of mud is not producing gas, as its appearance suggested, the gas was produced from about 2,430 cubic inches of mud. In the first case the mud would produce its volume of gas in about $10 \frac{1}{2}$ days and in the second case in about 6 days. These figures are only the roughest approximation to the truth, since there are many factors which can not be taken into account, but they indicate the order of magnitude of the production of marsh gas in the black muds of the coastal estuaries. A small fraction of the amount of gas specified above entrapped in the pores during the deposition of a thick mass of shale could charge a sandstone with all the gas it would hold.

At Brown's dairy farm, 6 miles southwest of Astoria, is one of the most interesting gas localities seen in the region. The gas escapes from a 2-inch pipe driven in 1905 in the bed of a slightly brackish slough in sec. 26, T. $8 \mathrm{~N}$., R. $10 \mathrm{~W}$. The pipe was driven to a depth of 10 feet beneath the bottom of the slough, the first 2 feet through a loose black clay, which is very soft and of light weight, and the remaining 8 feet through a "very fine grained hard-packed sand, which is good for polishing silverware." The description of the latter suggests diatomaceous earth, such as is seen on the bottoms of several fresh-water lakes in this region. Gas was not plentiful at first, but after a pump had been placed on the pipe and operated for half an hour a burst of gas appeared, and the gas has continued to flow ever since, mixed with brackish water. The water rises in the pipe about to the level of high tide, regardless of the phase of the tide. The gas is odorless and burns with a nearly colorless flame. On the bank of the slough is a rude separator and tank made of barrels connected with gas pipe, by means of which Mr. Brown reports that he formerly secured enough gas from the water to operate one or two jets. Much gas bubbles from the bed of the slough, especially when the mud is agitated. The little iridescent films on the water at this place, which resemble oil, are mostly iron hydroxides, but a few of them could be drawn out with a stick after the manner of oil films. 
It is probable that these are minute traces of oil, but the oil may have formed in some way within the superficial deposits beneath the slough; and does not necessarily mean that oil is here escaping from the rocks. A similar pipe driven through sand and gravel in the same slough one-half mile farther south yielded no gas. Analyses of gas from this place are given as Nos. 1060, 1061, and 1063 on page 108.

An interesting arrangement for the utilization of marsh gas was made by John Nelson, at his ranch on Deep River, Wash. (sec. 30, T. 10 N., R. 8 W.), north of Astoria. Mr. Nelson made a shallow wooden air-tight collecting box 30 feet long and 13 feet wide and inverted it in the water of a shallow slough, where many bubbles of odorless gas escape. The gas from the box trap passes through gas pipe and hose to a small storage tank on the bank from which it is piped to the ranch house near by and used in a Welsbach burner. The quantity is sufficient to run one burner at least four hours every night, and the quantity could be doubled by building another trap. The quality of the gas is indicated by analyses 1062 and 1064 on page 108. Cheap gas plants like this could be operated on many of the sloughs near the Oregon and Washington coast.

It is generally impossible to tell whether gas like that at the foregoing localities, which bubbles up from the beds of sloughs, is marsh gas formed in the mud or gas which has escaped from the rocks below. The first explanation must apply to most of the gas localities, but there is no certain criterion for distinguishing them. The gas at this locality induced promoters to attempt to drill for oil near by, but after about 100 feet of soft clay shale had been penetrated the well was abandoned. No trace of gas was encountered.

GAS IN TERTIARY STRATA.

Of greater practical importance than the foregoing are traces of gas found in the Tertiary strata and traces of gas which occur under conditions that indicate its derivation from the underlying Tertiary. The former traces are from deep wells and the latter from "mineral" or salty springs in the mountains. The only gas which has been struck in quantity within the area of this reconnaissance is in the deep well near Dallas. (See p. 89.)

In Clatsop County only small traces of gas have been found in the Tertiary rocks, but no very deep wells have yet been drilled. The deepest traces are those reported by H. C. Harrison at depths below 630 feet, in a well he drilled in the tidal flat on the Hess farm, 2 miles south of Astoria, in sec. 29 , T. 8 N., R. 9 W. The well was 650 feet deep and was cased to a depth of 630 feet when the writer examined it in 1910. Water filled the casing to within 10 feet of the top, and no oily nor sulphide odor could be detected. On dropping a match in the open casing, the mixture of gas and air above the water 
exploded. The experiment failed on repetition, a few minutes later, indicating that the escape of gas is slow. Mr. Harrison states that the gas was more abundant before the well filled with water, but that it never afforded a flow of commercial significance. Near by is another well about 400 feet deep, which caved after the casing was drawn. Mr. Harrison reports that bubbles of inflammable gas and films of oil appeared frequently in both of these wells, but, as no tests were made, the supposed oil may have been iron films, and indeed was probably so, for they are said to have disappeared from the surface of the water in a barrel in which they were caught (probably sinking as limonite to the bottom). The wells penetrated shale and sandstone, of which no good log is available.

Mr. Harrison also drilled a well 280 feet deep at his machine shop in Warrenton, in sec. 21, T. 8 N., R. 10 W. Gas was struck at 140 feet, which threw the water 10 or 15 feet out of the casing and which, according to report, "sustained a good flame when lighted." At the time of the writer's reconnaissance this well had caved and was covered with sand, preventing examination. It is reported that gas still escapes from a shallower well at the Oregon mill, also in Warrenton. The Quaternary materials, mostly river and wind deposits, are thought, from the record of the well at Fort Stevens, 3 miles northwest of Warrenton (p. 52), to reach greater depths than these gas horizons.

Several mineral springs in the southern part of the county, according to report, give off inflammable gas. Three were examined. The first, Pope's mineral spring, near Elsie, in the NW. $\frac{1}{4}$ sec. 5, T. 4 N., R. $8 \mathrm{~W}$., contains only hydrogen sulphide gas.

The second "spring" is indicated by bubbles of methane which issue from the gravel bottom of Nehalem River, at a well-known spot in the SW. sec. 7, T. 4 N., R. 7 W., below the house of Mr. Lukkarila. The gas is probably not marsh gas formed in the thin coating of coarse gravel, but comes out of the underlying shale, which is exposed in places where the gravel has been swept away. The quality of this gas is shown by analysis 1067 on page 108 .

An odorless inflammable gas issues from a spring of alkaline salty water, near the bank of Nehalem River, one-fourth mile below Mr. Herrick's house at Grand Rapids. (See analysis 1065 on p. 108.) The spring is located on a gravel terrace, but the water comes from fissures in the rock and passes through 15 or 20 feet of gravel before reaching the surface. Near by, similar water escapes in smaller quantity directly from fissures in the bedrock exposed on the margin of the river. The water is of a type distinctly different from the meteoric water of the humid belt in which this region lies, and it is improbable that the salt and "alkali" could have been derived directly from any part of the local rocks that lie close to the surface. The water, 
however, is not noticeably warm. The bedrock through which it issues is one of the hard thin-bedded micaceous fluviatile sandstones near the top of the Eocene basaltic breccias. A large basalt dike about 100 feet thick outcrops 200 yards west of the spring. The dike trends north and south and dips $60^{\circ} \mathrm{E}$., probably passing under the spring at considerable depth. The rocks are fractured and cut by small faults. Other springs of similar type are reported in the same region but were not examined.

\section{TILLAMOOK COUNTY.}

\section{GEOLOGY.}

NEHALEM AND WILSON RIVER BASINS.

The rocks of Tillamook County are largely igneous. Necarney Mountain, in the northwest corner of the county, is composed of a coarse-grained-basic igneous rock (dolerite) intrusive in the shale and sandstone exposed on its north flank in Clatsop County, and on its south flank in Tillamook County. At the west end of this dolerite mass a shale, probably corresponding to the Astoria shale and carrying Oligocene (?) fossils, outcrops in the low bluffs back of the beach north of Cape Falcon. Similar shale, indurated by contact metamorphism, outcrops on the slope of the mountain in sec. 4, T. 3 N., R. $10 \mathrm{~W}$. About 70 feet of hard sandstone is in contact with the igneous rock on the south along the wagon road in course of construction from Nehalem to Seaside. Its abnormal dip of $10^{\circ} \mathrm{NE}$. is probably due to igneous disturbance, as are also the irregular dips observed by Diller in the mass of sandstone farther east, which contain thin coal beds. Traces of coal were observed in the sandstone in sec. 18, and it is reported that a prospector has uncovered about 18 inches of coal in that locality. According to Diller ${ }^{1}$ coal outcrops at intervals from sec. 16, T. 3 N., R. 10 W., northeast to sec. 36, T. 4 N., R. 10 W., a distance of about 5 miles. The coal in sec. 18 lies about 2 miles west of this line, but the intervening territory is occupied mainly by igneous rock. The Astoria (?) shale outcrops south of the coal-bearing sandstone at a lower stratigraphic horizon, as indicated by the dips. The coal-bearing formation therefore may be the same as the fresh-water sandstone above the marine rocks east of Astoria.

Most of the eastern part of Tillamook County is underlain by basic lavas, agglomerates, and tuffs, which contain a few intercalated beds of sandstone, conglomerate, and shale, and locally carry Eocene fossils.

At the entrance to Wilson River canyon, 5 miles east of Tillamook, the river flows over hard dark-blue basalt, which is amygdaloidal in

I U. S. Geol. Survey Seventeenth Ann. Rept., pt. 1, p. 494, 1896. 
places. The amygdules and fissures contain much calcite and some zeolites. The basalt is unconformably overlain on the west by 20 feet or more of avery coarse conglomerate, thoroughly cemented and composed mainly of basalt bowlders, some of which are 3 feet in diameter. On the hillside, 150 feet above the conglomerate, is a good exposure of nearly horizontal soft massive sandstone with conglomeratic layers. The sandstone is over 100 feet thick, unless sliding has increased its apparent thickness, and it contains poorly preserved casts of marine fossils, probəbly Miocene.

According to Diller ${ }^{1}$ there is much conglomerate of eruptive material near Felix Roy's, on Nehalem River, about 5 miles east of Nehalem post office. Eocene fossils were obtained at this place in a heavy bed of tuff "about 22 miles northeast of Tillamook, on the Wilson River toll road, a short distance above Smith's:" Near the mouth of Fall Creek, in the canyon, Diller noted the occurrence of shale and sandstone among the larger masses of igneous rocks.

He found ${ }^{2}$ concretionary sandstone at the old jetty quarry on the southwestern shore of the bay, in which Miocene fossils were mingled with Oligocene forms. The latter are possibly in extraneous concretions which were derived from adjacent older rocks, as suggested by Diller, or possibly the locality presents another instance of the blending of supposed Oligocene and lower Miocene faunas which has confused the writer at many places in northwestern Oregon. However, there can be no doubt of the presence of the Oligocene at Tillamook Bay, because Oligocene fossils were found at that place by Diller in 1895 and by the writer in later reconnaissances. In the Condon Museum of the University of Oregon is a specimen of the characteristic Oligocene fossil Aturia angustata Conrad, which was found by Condon in a calcareous concretion at Tillamook.

In soft shale, locally calcareous and much crushed, Diller ${ }^{3}$ collected Miocene fossils at Crawford's ranch on North Fork of Nehalem River, about 6 miles above Nehalem post office. What is supposed to be the Astoria shale is poorly exposed at many places in this region. The fossils resemble those seen at the top of the Astoria shale, but, except for those recorded by Diller, only imperfect fragments have been found.

On the wagon road from Garibaldi, on Tillamook Bay, to Balm, near Nehalem Bay, the rock exposed is wholly igneous, mostly basaltic lava, with some masses of black scoria and bedded tuff. It is reported, however, that there is a fossiliferous sandstone at an altitude of about 1,200 feet on the hills near Crane's ranch in sec. 35, T. 2 N., R. $10 \mathrm{~W}$. A cast of a remarkably large limpet was obtained from a loose fragment of sandstone which had rolled down the hill at Crane's ranch. 
Along the railroad, on the east side of the bay between Bay City and Garibaldi, there are several exposures of shale and sandstone, dipping in general from $10^{\circ}$ to $15^{\circ} \mathrm{W}$., but the strike swings to east and west in the northern part of the section and the dip becomes variable. Four miles from Tillamook the railroad cuts through 10 feet of light-brown sandstone, and a mile farther north, near the Bay City wharf, a long excavation exposes about 120 feet of gray sandstone, striking $\mathrm{N} .10^{\circ} \mathrm{W}$. and dipping $16^{\circ} \mathrm{W}$. North of this there may be a syncline, for in the next exposure, one-half mile from the Bay City wharf, the dip is $20^{\circ}$ to $40^{\circ} \mathrm{S}$. The top stratum here is 50 feet of sandstone, like the preceding, but cut by many slickensided fractures. Below the gray sandstone is 15 feet of dark clay shale with thin hard calcareous layers, overlying 40 feet of brown massive sandstone, below which is nearly 100 feet of dark clay shale with many 6-inch partings of calcareous sandstone. The lower shale is cut by sandstone dikes.

In the next exposure, one-fourth mile to the north, 20 feet of dark clay shale, dipping $10^{\circ} \mathrm{N}$., is exposed. Between the two exposures no rocks are visible, and the relations on the two sides can be explained only on the assumption that an anticline or fault is present. Thirty feet of hard micaceous sandstone outcrops one-fourth mile from the preceding exposure, in beds 6 inches to 3 feet thick, which strike N. $35^{\circ} \mathrm{W}$. and dip $30^{\circ} \mathrm{NE}$. Two hundred yards north of this, at a small waterfall, the strike is $\mathrm{N} .50^{\circ} \mathrm{W}$. and the dip $87^{\circ} \mathrm{NE}$., probably from the influence of a fault. Three hundred yards beyond this and $1 \frac{1}{2}$ miles from the Bay City wharf clay shale dips $10^{\circ} \mathrm{N}$. At Hobsonville the railroad tunnels through the point of a basalt hill 2 miles from Bay City. At the north end of the tunnel a black baked shale dips $25^{\circ} \mathrm{SW}$., and 200 yards farther north a hard yellow clay shale dips $15^{\circ} \mathrm{N}$. Both banks of Miamie River, at the railroad bridge, 3 miles from Bay City, are composed of coarse-grained basic igneous rocks (dolerite?). The next exposure is $1 \frac{3}{4}$ miles west, at the Garibaldi wharf on the north shore of Tillamook Bay, where 25 feet of hard, white-weathering shale, apparently baked by igneous rock, strikes N. $25^{\circ} \mathrm{W}$. and dips $25^{\circ} \mathrm{SW}$.

At the north point of the bay, one-half mile west of Garibaldi, an outcrop of thick-bedded conglomeratic sandstone with a few thin clay partings contains pebbles of quartz, brown sandstone, white baked shale, and pyritiferous basalt (?), about one-fourth inch in diameter. The strike is $\mathrm{N} .35^{\circ} \mathrm{W}$. and the dip $40^{\circ} \mathrm{SW}$. Rock of probably the same sandstone lies offshore in the ocean, and it outcrops near the lifesaving station one-half mile north of the point. The sandstone at the latter place is fine grained, indurated, hard, and very micaceous; it strikes $\mathrm{N} .35^{\circ} \mathrm{W}$. and dips $38^{\circ} \mathrm{SW}$. It is estimated that there is about 500 feet of sandstone near the point and the life-saving station, but the estimate may be erroneous, because of the presence between outcrops of large masses of basalt about 40 feet high. 
The strata lying below the conglomeratic sandstone are thought to be Oligocene. The conglomeratic sandstone is thought to be the base of the mass of Miocene sandstone and shale that outcrops on the south side of Tillamook Bay and at intervals for several miles southward. It is possible that the sandstone near the Bay City wharf is the same as the conglomeratic sandstone at the point, but the strike seems to carry the latter across the bay to the old jetty quarry, northwest of Tillamook, where the massive sandstone contains many Astoria (Miocene) fossils. Diller, ${ }^{1}$ who made the first collection at the quarry, found three species supposed to be characteristic of the Oligocene and offered the explanation that at the time of deposition Oligocene fossils had been washed into the Miocene sand as extraneous pebbles.

Although the sections given above are too badly broken by wide gaps to permit definite correlation, it is evident that the stratigraphic column at Tillamook Bay must be very different from that at Astoria, only 50 miles away. The Eocene volcanic sediments and associated sandstones east of the bay may be correlated with those near Megler, on the north bank of Columbia River, opposite Astoria. But the shale exposed about Tillamook Bay does not approach the thickness of the Astoria shale (about 1,500 feet). The shale and part of the sandstone on the northeastern part of the bay are thought to represent the lower part of the Astoria shale. They contain only Aturia, Pseudamusium, and Foraminifera, and they can not be more than a few hundred feet thick, barring faults. The conglomeratic sandstone at the point west of Garibaldi, which is probably unconformable on the underlying sandstone and shale and is probably equivalent to the sandstone near the old jetty quarry on the southwest side of the bay, may be regarded tentatively as equivalent to the sandstone, which conformably (?) overlies the Astoria shale at Huntington Point, opposite Astoria, and which carries a fauna essentially the same as that at the jetty quarry, barring the Oligocene forms collected by Diller. If this assumption be correct, the upper part of the Astoria shale must be represented mainly by sandstone and sandy shale at Tillamook Bay, or else be absent. The correlation of the Miocene (?) sandstone which unconformably overlies the Eocene basalt and agglomerate at the entrance to Wilson River canyon, 5 miles east of Tillamook, must await the discovery of more fossils. These remarks are offered only as suggestions, in the attempt to clarify the stratigraphic problem, which can not be regarded as solved.

TILLAMOOK RIVÉR BASIN.

Between Tillamook and Netarts Bay the cuts along the wagon road expose only weathered yellow clay shale crossed by a few sandstone dikes, except in a cut $2 \frac{1}{2}$ miles west of Tillamook post office, where 
3 feet of sandstone is overlain by clay shale, dipping $4^{\circ} \mathrm{W}$. At 3 miles from the post office the shale. dips $7^{\circ} \mathrm{W}$; and at $3 \frac{1}{2}$ miles it strikes $\mathrm{N} .10^{\circ} \mathrm{W}$. and dips $15^{\circ} \mathrm{SW}$.; west of the last point there are no exposures. This possibly indicates a thickness of several hundred feet of shale; the stratigraphic relations of which are unknown. The strike of the rocks would carry the heavy sandstone at the old jetty quarry and near Mears Point through this section, but it was not seen.

For 3 miles south of Tillamook the hills are low and rolling with broad gravel-covered terraces along the streams. Shale is poorly exposed in places on the stream banks. Clay shale in the NW. $\frac{1}{4}$ sec. 10, T. 2 S., R. 9 W., about half a mile below the prospect well of the Portland Coal \& Development Co., strikes N. $25^{\circ}$ E. and dips $17^{\circ} \mathrm{NW}$. The timbered hills east of this locality were not examined. The gravels washed from them by the streams are not igneous, as is usually the case but are of soft brown argillaceous sandstone. At the mouth of Killum Creek may be seen about 20 feet of clay shale composed of dark-colored clay layers 3 to 6 inches thick, alternating with lighter-colored micaceous layers 6 to 12 inches thick. The strike is N. $20^{\circ} \mathrm{E}$. and the dip $11^{\circ} \mathrm{NW}$.

Southward up the Tillamook River road from South Prairie, the first good exposure is at the bridge across Killum Creek in sec. 16, T. 2 S., R. 9 W., where 80 feet of shale strikes N. $25^{\circ}$ E. and dips $10^{\circ} \mathrm{NW}$. Half a mile farther south, in the bed of a small creek, similar shale with concretions dips about $10^{\circ} \mathrm{W}$. The next 2 miles are without exposures, but on the adjacent bluff of Tillamook River, in sec. 18, T. 2 S., R. 9 W., about 25 feet of gray thick-bedded sandstone may be seen dipping $8^{\circ} \mathrm{W}$. At intervals for the next $2 \frac{1}{2}$ miles imperfect outcrops of weathered shale or clay occur, in which the structure is not determinable with certainty, although there is a suggestion of bedding planes dipping westward at low angles. Near the sawmill, 11 miles south of Tillamook, micacecus clay shale strikes N. $60^{\circ}$ E. and dips $5^{\circ} \mathrm{NW}$.

NESTUGGA RIVER BASIN.

In the next half mile southward across the divide to the Nestugga drainage several outcrops of the same kind of shale strike N. $5^{\circ}-25^{\circ} \mathrm{E}$. and dip $10^{\circ}-15^{\circ}$. NW. The shale reappears at Hemlock post office, $12 \frac{1}{2}$ miles from Tillamook, with indeterminate dip. On Beaver Creek, 1 mile below Hemlock, in sec. 18, T. 3 S., R. 9 W., about 100 feet of hard sandstone strikes N. $45^{\circ} \mathrm{E}$. and dips $15^{\circ} \mathrm{NW}$. Two hundred yards downstream the rock is basalt, which is quarried a mile farther down the creek. The rocks from this quarry to Bearer are concealed, and for a mile south of Beaver the outcrops are all 
basalt, but it is reported ${ }^{1}$ that near this place there is shaly limestone, which is used satisfactorily for road dressing.

South of Beaver to Hebo (5 miles) baked contorted shale appears between the outcrops of basalt, and 4 miles from Beaver, in a bluff on Nestugga River, soft sandstone and shale dip $10^{\circ}-15^{\circ} \mathrm{NW}$. Near Hebo the rock exposed is mostly diabase and basalt, largely in dikes, intrusive in clay shale. The first 3 miles south of Hebo presents similar geology, at the end of which is a ravine about 200 feet deep, with basalt and sandy basaltic agglomerate on its walls. Beyond the coarse-grained diabase or dolerite which shows at places in the next mile, poor outcrops of clay shale and argillaceous sandstone dip $15^{\circ}-18^{\circ} \mathrm{NW}$., and 3 miles farther south (301 miles from Tillamook) the shale dips about $3^{\circ} \mathrm{SE}$. Eastward dips of $5^{\circ}$ to $15^{\circ}$ in clay shale continue to Dolph and at intervals eastward for 10 miles, beyond the summit of the Coast Range into Yamhill County.

The dips suggest that there is an anticline of some sort 1 to 2 miles west of Dolph. This anticline appears to be the principal structure of this part of the Coast Range. The traverse sections made in this county show that every anticlinal fold is cut by dikes of igneous rock, and probably faults are equally abundant. Many small folds appear to have been uplifted by the intrusion of igneous rocks. The chances of getting oil in such structures are slight.

\section{INDICATIONS OF OIL.}

The writer has never been able to verify personally any indications of oil and natural gas in Tillamook County. Every so-called "seep" examined has proved to be only a film of iron hydroxide on the water. The prospect wells in which traces of oil and gas are reported contained no sign of these substances in the baling water nor about the wells when they were visited in 1910, although it is not impossible that small amounts of gas may have been struck and completely cased off previous to the examination.

\section{NEHALEM BEESWAX.}

The oil men have placed much faith on the Nehalem beeswax as an indication of oil, relying on the erroneous reports of early chemists and more recently of commercial analysts who have called it variously "oil residue," "paraffine," or "ozokerite." The wax occurs in the older beach sands immediately north of the entrance to Nehalem Bay, especially near the ranch of Edward Lane, about 3 miles north of the entrance. The wax on the surface has largely been gathered by professional collectors and tourists, but considerable quantities

1 Parks, H. M., Road materials in the Willamette Valley: Oregon. Agr. Coll. Dept. Geology Bull. 1, p. 43,1911 .

$47196^{\circ}-$ Bull. $590-14-5$ 
have been uncovered recently by digging through the sand to near tide level. The material has been distributed through the sand by the drift action of the wind, and it has so long been an object of curiosity to men, who have picked it up and dropped it about the sand dunes and farther inland, that no reliable evidence of its original distribution can be obtained. The great scarcity of the wax above levels reached by recent storm waves suggests that its original distribution was below these levels, or not more than 10 to 15 feet above ordinary high tide.

Commercial trade in the wax began about 100 years ago, when the Indians carried it to the Hudson Bay post at Astoria, but the total amount removed can not be accurately estimated. Mr. Lane states that he and others have gathered several thousand pounds in the last 10 years and shipped it to outside places, where it is sold as ordinary beeswax and used for all purposes to which beeswax is applied. The surface supply is now practically exhausted, but the drifting of the sand uncovers a few pieces each year. That the wax has been worked into shape by men is shown by the regular forms in which it occurs and by the markings on it. The large pieces are mostly from rectangular cakes, originally 2 to 6 inches thick and 1 to 2 feet across; most of which have been broken in the sand and the pieces separated, although a few almost perfect cakes have been found. The markings on the cakes consist of cut letters and numerals, which are commonly thought to be ancient trade-marks or symbols designating the original owner. The writer examined a symbol resembling a letter $L$ or figure 7 on a fragment of about 20 pounds weight in the possession of Mr. Lane. The symbol had been deeply cut with a rough-edged tool, as shown by the parallel striations in the groove. That it is genuine is indicated by the fact that the surface of the wax within the groove has the same peculiar mottled brown color due to age as that of the rest of the specimen. A few slender cylindrical fragments are regarded as early types of candles from which the large wicks have rotted away.

Chemical analyses by H. N. Stokes, of the United States Bureau of Standards; O. F. Stafford, ${ }^{1}$ of the University of Oregon; C. E. Bradley, of the experiment station, Oregon Agricultural College; and many other chemists of high standing have shown that the wax contains organic compounds unknown in "mineral" hydrocarbons but present in beeswax, and which only bees are known to produce. According to Stafford, one of these substances is foreign to American bees and known only in the beeswax from southeastern Asia. It is generally thought that the wax came from some ship, loaded mainly. with beeswax, which was wrecked on the beach long previous to the first settlement of the region. Whatever its source, there is no doubt as to its nature, and no ground remains for calling it ozokerite. It has

1 Oregon Hist. Soc. Quart., vol. 9, pp. 24-41; March, 1908. 
no more connection with the occurrence of oil than the primitive Spanish cannon found 9 miles farther north in the sands of Cannon Beach.

OTHER FALSE INDICATIONS OF OII.

Fragments of "paraffine sandstone," really beach sand cemented by wax, were collected on the beach at the same locality where the wax cakes occur. The "sandstone" is soft and may be crushed between the fingers. It is somewhat plastic, especially when gently heated over a candle, and when subjected to greater heat it falls to pieces. Most of the fragments contain so much wax that they literally melt when heated, and in that condition the wax may be separated from the sand. The "sandstone" burns when lighted. Stafford states that the wax in the "sandstone" is the same as that of the cakes, and he explains its presence in the sand by the plausible hypothesis that fires in the great piles of driftwood, which characterize the Oregon sea beaches, may have melted some of the wax, causing it to run into the beach sand.

In the beach sand and in the high dunes back of the beach many similar "sandstones" have been found. The samples of these submitted to the writer were almost like the wax-cemented sand in general appearance and in fusibility, but the cement is resinous material or pitch, which may have dropped from cracks in the ends of burning logs and penetrated the sand in the same way as the wax. There can be no stratified beds nor dikes of this material in the localities north of Nehalem Bay, where "oil-saturated sands" are reported to outcrop, because an examination of the reported localities reveals only broad stretches of sand dunes, largely timbered with small pine and covering the bedrock to an unknown depth. The pitchcemented sand is common on the Oregon coast, along which there is a great quantity of pitchy evergreen timber. Several specimens have been sent to the writer labeled "asphaltic sandstone." These are somewhat darker and firmer than is common, but on melting out the pitch its nature is made readily apparent by taste and color. No true asphaltic sandstone has been submitted from any locality in northwestern Oregon, and at this date the writer knows of none in the State.

\section{ASPHALTUM.}

Of greater interest as an oil indication is the report by G. H. Collier, of Eugene, Oreg., that about 35 years ago he found small veinlets of asphaltum cutting the rock in eastern Tillamook County, 6 miles southwest of Skukum Lake, at the head of a small creek entering Wilson River from the south. Comparison with the map suggests that this locality is in the northern part of T. $1 \mathrm{~N}$., R. $6 \mathrm{~W}$., but unfortunately precise location is not possible. Colljer writes that the veins are about one-half inch thick, black, and about as hard as 
the asphalt used in paving. The letter reporting this discovery was received after the completion of field work and hence.it was impossible to examine the locality, but on account of the competence of the observer his report is recorded here with the hope that the residents of the upper Wilson Valley may relocate the veins. The rocks of that region are largely igneous, with much volcanic sediment and sandstone containing Eocene fossils.

The great number of faults and dikes which cut the strata of Tillamook County, especially in the northern half of the county, weaken the rocks as an oil reservoir, and the volcanic rock will make deep drilling practically impossible in many places. The evidence does not warrant the belief that oil will be found in this county.

PROSPECT WELLS.

Two deep wells have been drilled in Tillamook County. The deeper well, which was abandoned in 1910 at a depth of about 2,532 feet, was drilled $5 \frac{1}{2}$ miles southeast of Tillamook, in the SE. $\frac{1}{4}$ sec. 10, T. 2 S., R. 9. W., by the Portland Coal \& Development Co. An accurate $\log$ is not available, and the following record was compiled by one of the drillers from memory only:

Approximate log of the prospect well of the Portland Coal \& Development Co., $5 \frac{1}{2}$ miles southeast of Tillamook, Oreg.

\begin{tabular}{|c|c|c|}
\hline$\cdot$ & $\begin{array}{c}\text { Thick- } \\
\text { ness. }\end{array}$ & Depth. \\
\hline 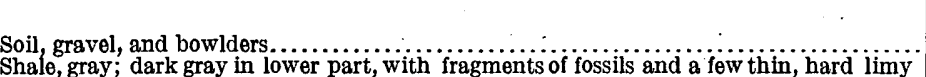 & Feet. & Feet. \\
\hline 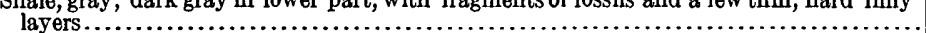 & 700 & 752 \\
\hline 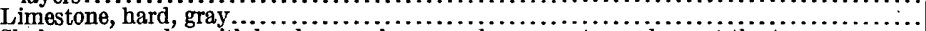 & 3 & 755 \\
\hline Shale, very sandy, with hard, green layers and some water and gas at the top.......... & 245 & 1,000 \\
\hline Shale, gray, softer than preceding; alternating layers of black and coffeo-colored clay rock. & 335 & 1,335 \\
\hline 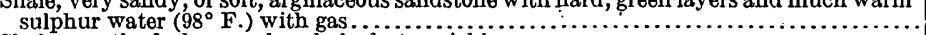 & 35 & 1,370 \\
\hline 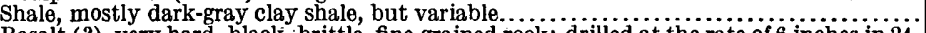 & 470 & 1,840 \\
\hline 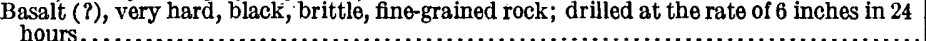 & 6 & 1846 \\
\hline Shale, mostly dark, with many hard layers from 2 to 5 feet thick, and two 6 or 8 foot beds & 0 & \\
\hline 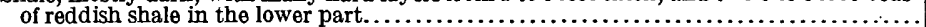 & 221 & 2,067 \\
\hline Sandstone, hard, gray; "show" of oil... & 22 & 2,089 \\
\hline Shale, dark colored, soft, caving........ & 443 & 2,532 \\
\hline
\end{tabular}

There are reports, not confirmed by neighboring ranchers, that at one time a flame of gas issued 4 feet above the casing. Only a little gas was escaping when the well was examined in 1910. 'Its composition is shown by analysis 1066 on page 108 .

Within a few yards of this well it is reported that a previous well reached a depth of about 700 feet without striking more than a "show". of gas.

Another well was drilled to a depth of about 1,500 feet in the sandcovered region north of Nehalem Bay, about 3 miles northwest of Nehalem, in about sec. 20, T. 3 N., R. 10 W., near the beach from 
which great quantities of ancient beeswax (p. 65) have been obtained. The well, which is the property of the Necarney Hydrocarbon Oil Co., had reached, when examined in 1910, a depth of 675 feet, mostly in shale. Traces of gas were reported at 250 feet and at various horizons between 500 and 600 feet, but no gas nor oil could be detected at the time of the writer's visit. It is said that the gas could be flashed off at the top of the casing. Through the courtesy of J. J. Walters, president of the company, the following log is given:

Log of Necarney Hydrocarbon Oil Co.'s well, 3 miles northwest of Nehalem, Oreg.

\begin{tabular}{|c|c|c|}
\hline V & $\begin{array}{l}\text { Thick- } \\
\text { ness. }\end{array}$ & Depth. \\
\hline & Feet. & Feet. \\
\hline 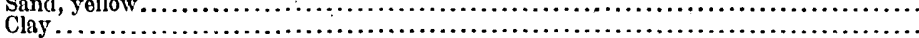 & $\begin{array}{r}60 \\
5\end{array}$ & $\begin{array}{l}60 \\
65\end{array}$ \\
\hline 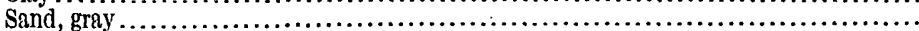 & 10 & 75 \\
\hline 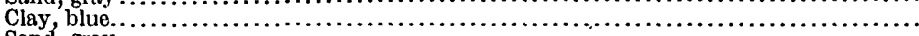 & 10 & \\
\hline 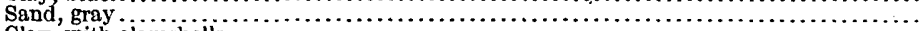 & 10 & 95 \\
\hline 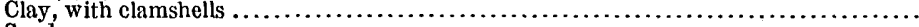 & 15 & 110 \\
\hline 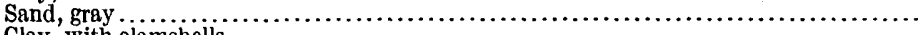 & 5 & 115 \\
\hline 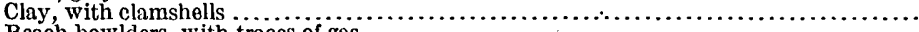 & 135 & 250 \\
\hline 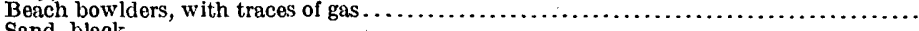 & 5 & 255 \\
\hline 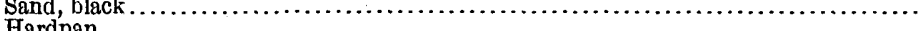 & 5 & 260 \\
\hline 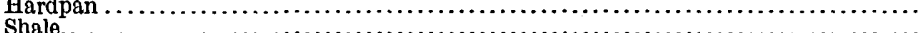 & 45 & 305 \\
\hline 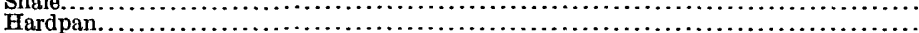 & 20 & 310 \\
\hline 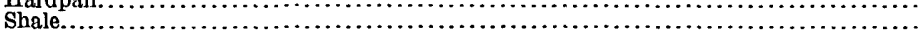 & 15 & 380 \\
\hline 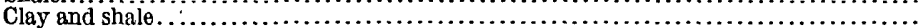 & 30 & 375 \\
\hline 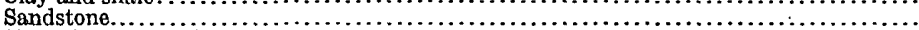 & 10 & 385 \\
\hline Shale, light colored... & 10 & 395 \\
\hline 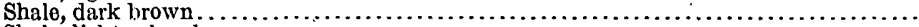 & 10 & 405 \\
\hline 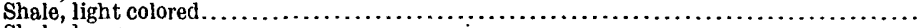 & 55 & 460 \\
\hline 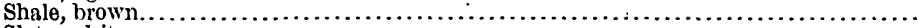 & 50 & 510 \\
\hline 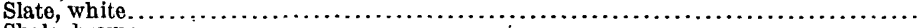 & 10 & 520 \\
\hline 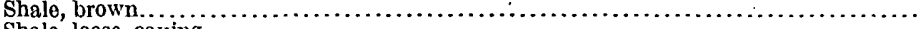 & 30 & 550 \\
\hline 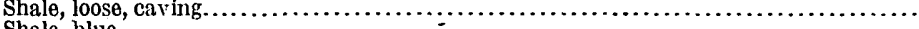 & 10 & . $\quad 560$ \\
\hline 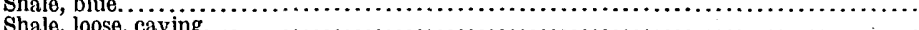 & 15 & 575 \\
\hline 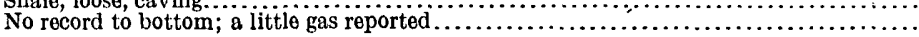 & \pm 915 & $\pm 1,500$ \\
\hline
\end{tabular}

From the general stratigraphic relations indicated by imperfect exposures northeast of the well and from the character of the strata penetrated it seems probable that the well is being drilled in the Astoria shale.

\section{COLUMBIA COUNTY.}

GEOLOGY.

Columbia County lies east of Clatsop County and west of the northward bend of Columbia River. In a general way its geology is similar to that of Clatsop County, especially that of its western part, where the same formations prevail with little change. It has, however, fewer dikes of basalt or other intrusives except in its southern part.

NORTHEASTERN COLUMBIA COUNTY.

Lava flows, agglomerates, and tuffs cover the eastern margin of the county along Columbia River. Between St. Helen and Rainier the lavas are largely andesites, with hypersthene or hornblende or both, rarely dacitic with a little quartz. These rocks are of types 
foreign to the Coast Range farther south, and as the same rocks occur across the Columbia in Washington it is possible that they are the western edge of flows from the Cascade Mountains. The lava mass was not studied in detail, but it is more than 3 miles wide near Goble, and is said to extend 10 miles from the Columbia at localities farther south. It appears to be later than any of the sedimentary rocks of the region and is presumably Pliocene or younger. The top of the lava lies at altitudes of 300 to 700 feet on the Oregon side of the river and is much lower on the Washington side, suggesting a north-south fault along Columbia River, to which the northward deflection of the river may be due. At many localities in this lava belt the rock is basaltic, and southward it becomes almost wholly basalt, possibly in part intrusive, and extends with minor interruptions into western Multnomah County. Its relation to the andesite is unknown.

Basalt is well exposed between Mayger and Rainier along the railroad, but between the two railroad tunnels west of Ranierson the rock is fragmental black tuff and agglomerate. Amygdaloidal basalt is overlain by 8 feet of leaf-bearing clay capped by 20 feet of soil in a well near the top of a flat ridge 2 miles southeast of Rainier. The fossil plants collected at this place in 1910 are not sufficient to determine the age of the basalt, but they resemble trees now living in that region.

Over 20 feet of white baked clay cut (?) by basalt may be seen three-fourths of a mile west of Rainier, and soft micaceous sandstone containing pebbles of quartzite, gneiss, basalt, and weathered coarsegrained igneous rocks outcrop one-fourth mile west of the town. In a railroad cut a quarter of a.mile east of Rainier is 40 feet of dacite, tuff, and agglomerate, dipping $15^{\circ} \mathrm{S}$. Near the section house and about 50 feet below the tuff is 15 feet of bluish clay, weathering gray and containing thin partings of coal. The dip is about $30^{\circ} \mathrm{S}$. These observations indicate that the lavas near Rainier are associated with fresh-water sedimentary rocks, the age of which is unknown. D. P. Gerdes, of Houlton, reports that an extinct geyser cone stands in a lake near that village. Calcareous spring deposits are common in the volcanic area along Columbia River in this county.

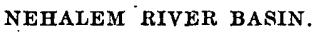

Sedimentary rocks underlie most of Columbia County, excluding the eastern margin. The known Eocene strata are limited to the southwestern corner. Oligocene and lower Miocene rocks are common in the western half of the county and upper (?) Miocene in the southeastern and northern parts. Near Vernonia and Clatskanie, Diller ${ }^{1}$ found the only marine Pliocene rocks known in northwestern Oregon.

Diller ${ }^{2}$ observed good exposures of fossiliferous Eocene or Oligocene shale on Rock Creek from 6 to 10 miles above Vernonia. At several 
places cliffs of shale contain large concretions and thin sandy layers. The latter under microscopic examination are found to be composed almost wholly of material derived either directly from volcanoes or by erosion from igneous rocks. The shale weathers gray, but on a fresh fracture is dark, containing much vegetal matter. It strikes N. $82^{\circ}$ E. and dips very gently southeast away from the older rocks in the region of the Rock Creek mines. In the field Diller thought this shale was the lower part of the Oligocene series. exposed on the Nehalem at Wilsons Bluff, 1 to 3 miles above Vernonia. The apparent continuity of the shale with that on the head of Rock Creek in the southwest corner of Clatsop County strengthens this suggestion, but the abundance of volcanic material is characteristic of the Eocene and not of any shale of certain Oligocene age found by the writer.

From the lithologic evidence Eocene formations seem to be possibly extensive in Columbia County, but the general lack of fossils makes their identification uncertain. In the southwest corner of the county and extending up Rock Creek into Clatsop County the few outcrops of volcanic agglomerate are of probable Eocene age. The shale on the lower part of this creek has Eocene fossils at the base and Oligocene fossils at higher horizons.

Farther east in the upper Nehalem coal field, on Pebble Creek, on the east fork of the Nehalem and on the Clatskanie, are massive sandstones of probable Eocene age, which dip $8^{\circ}-12^{\circ} \mathrm{SE}$. and are associated with beds of "black lignite" or subbituminous coal, which have been described by Diller. ${ }^{1}$ The coal-bearing Eocene outcrops $2 \frac{1}{2}$ miles west of Valley, dipping southeast at a low angle, in sec. 27, T. $5 \mathrm{~N}$., R. $3 \mathrm{~W}$., and in secs. 23 and 24 , T. 4 N., R. 4 W. In sec. 23 the dip is $10^{\circ} \mathrm{SE}$. and in sec. 34 it is $8^{\circ} \mathrm{SE}$. The three localities are on a strike line running about $\mathrm{N} .40^{\circ} \mathrm{E}$., and they may be connected, but on the same general line in sec. 27, T. 4 N., R. 4 W., are coal-bearing rocks, in which Diller ${ }^{2}$ obtained Miocene or Oligocene fossils. The structure and continuity of the beds are very uncertain, but they probably lie on the east side of an anticline or fault, as a parallel line of exposures along Nehalem River, about 6 miles northwest, appears to be almost wholly Oligocene and Miocene.

Oligocene and lower Miocene shale and sandstone are widespread in Columbia County, and locally they are abundantly fossiliferous. The greater part of the course of Nehalem River in this county is over shale which is thought to be, in the main, equivalent to the Astoria shale, with which it is continuous in southeastern Clatsop County. The fossils are characteristic of the Astoria shale, most of them being referred with doubt to the Oligocene, with an alternative possibility of lower Miocene age. The new fossil localities are (5389) SE. $\frac{1}{4}$ sec. 8, 
T. 6 N., R. 5 W., 11 miles northeast of the mouth of Fishhawk Creek; (5390) clay bluff, one-fourth mile southeast of Mist, on Nehalem River; (5391) 3 miles east of Mist, in a bluff on the river, in the SE. $\frac{1}{4}$ sec. 2, T. 6 N., R. 4 W.; (5392) 8 miles above Mist, on the river, in sec. 11, T. 5 N., R. 4 W. The preceding localities are all in clay shale, mostly concretionary, resembling the Astoria shale and containing the same fossils.

A somewhat different fauna is represented by a collection (5393) made in blue limestone about a mile south of the last-named locality and a mile or more below Pittsburg, in the SE. $\frac{1}{4}$ sec. 14, T. 5 N., R. $4 \mathrm{~W}$. This fauna is referred without doubt to the Miocene. The dips would indicate that it underlies the shale previously mentioned and also the Eocene strata exposed one-fourth mile southwest (5394) in a cut on the Pittsburg road, in the NW. $\frac{1}{4}$ sec. 23 , T. 5 N., R. 4 W. The Astoria shale extends for 10 miles up the Nehalem above Vernonia, dipping eastward, and appears to pass beneath this formation. The Eocene (5394) at Pittsburg therefore seems to occupy an anomalous position, which, like many similar anomalies encountered in the Coast Range, can be explained only by the supposition that faults are present between the outcrops. There is no room for other structures. It should be remembered, however, that the fossils are not absolutely reliable, because of their poor preservation and because, owing to the lack of good type sections and stratigraphic knowledge, they can not be accurately located in their various stratigraphic horizons.

In the same region, Diller ${ }^{1}$ made several collections of Oligocene or lower Miocene fossils. On the road to Mist, 2 miles southwest of Clatskanie'and 150 feet above the river, he found a fossiliferous nodule in soft sandstone dipping northerly (?), and on the same road, at 700 feet above the river, he found Pliocene fossils in shaly, sandstone. On the north fork of the Scappose, about 5 miles northwest of the station of the same name, he found soft gray fine jointed sandstone, with Oligocene fossils, striking N. $40^{\circ} \mathrm{W}$. and dipping $19^{\circ} \mathrm{SW}$. In a bluff of Nehalem River near Pittsburg he observed 30 feet of fossiliferous soft gray thin-bedded sandstone, overlying 20 feet of dark gray weathering shale. The dip here is about $5^{\circ} \mathrm{NE}$. Particles of pumice occur among the sand grains. Lower beds of shale, dipping gently eastward, occur farther up the Nehalem and at a point 1 to 3 miles above Vernonia. On Rock Creek Diller ${ }^{2}$ observed that "the Oligocene shale is covered by Pliocene tuffs and is succeeded westward by Eocene shale and underlying volcanics," which is in conformity with the evidence obtained in 1910, except that the Pliocene tuffs were not seen. Near Mist Diller ${ }^{3}$ observed whitish tuffaceous 
radiolarian shale overlying fossiliferous dark shale. A few fossils referable to the Astoria shale were found in the latter in 1910. Four miles above Mist Diller collected upper Miocene fossils from a prominent bluff of nearly horizontal sandstone.

Along Nehalem River upstream from the western margin of the county the dips in the Astoria shale are southeastward at low angles $\left(2^{\circ}-6^{\circ}\right)$ as far as the middle of T. 6 N., R. 5 W., above which low northwest dips $\left(2^{\circ}-5^{\circ}\right)$ prevail to the eastern margin of the township, where the shale is horizontal. Just west of the county line on the wagon road to Vesper 9 feet of micaceous sandy shale dips $5^{\circ} \mathrm{SE}$. above 7 feet of dark clay shale which dips $15^{\circ} \mathrm{SE}$. The contact of the two resembles an unconformity but is not marked by sandstone nor conglomerate. The upper sandy shale contains plant impressions resembling reeds. In similar shale, near the mouth of Fishhawk Creek, in the SE. $\frac{1}{4}$ sec. 8 , T. 6 N., R. 5 W., fragments of leaves and unrecognizable casts of bivalves were seen. One-fourth mile below this on the Nehalem is 20 feet of dark micaceous clay shale, dipping $6^{\circ} \mathrm{E}$. Sandy shale one half mile above the mouth of the Fishhawk yielded Oligocene or lower Miocene fossils (5389). The dip here is about $10^{\circ} \mathrm{NE}$. At Mist dark laminated clay shale dips $2^{\circ}-5^{\circ} \mathrm{W}$., and one half mile above Mist, on the Nehalem, is a bluff about 100 feet high, from the lower part of which many fossils (5390) wore obtained in gray clay shale full of Foraminifera. These fossils are Oligocene or lower Miocene. The dip is $2^{\circ} \mathrm{NW}$. (?). At Holmes's ranch, 2 miles above Mist, clay shale in the bed of Nehalem River dips $4^{\circ}$ E. or SE. Three miles above Mist, in the SE. $\frac{1}{4}$ sec. 20, T. 6 N., R. 4 W., a 50-foot bluff of bedded gray clay, similar to the last, contains many of the same fossils (5391). The dip is $4^{\circ} \mathrm{SE}$. Onehalf mile farther up the Nehalem a road cut exposes 35 feet of nearly horizontal sandstone, gray and massive in the upper part, and yellowish and thin-bedded in the lower. Four miles above Mist the river flows over gray sandy shale dipping about $3^{\circ} \mathrm{S}$. Low dips, probably southeastward, are seen at a few poor exposures for the next 4 miles upstream, to an exposure in the bed of the Nehalem, in sec. 11, T. 5 N., R. 4 W., where soft massive argillaceous sandstone, containing Oligocene or lower Miocene fossils (5392), dips $3^{\circ}$ SW. (?).

Near Pittsburg, a mile above the last-mentioned locality, two exposures, one Miocene and the other Eocene according to the fossils, are separated by an interval of about 250 yards in which no exposures were seen. The Mioceng fossils (5393) wore obtained from a 6-inch bed of blue limestone, at water level in Nehalem River, in the SE. $\frac{1}{4}$ sec. 14, T. 5 N., R. 4 W. The limestone is interbedded in soft fine-grained silty or argillaceous sandstone which strikes N. $50^{\circ} \mathrm{E}$. 
and dips $7^{\circ} \mathrm{NW}$. Eocene fossils (5394) were found in a road cut 250 yards southwest of the Miocene locality and near the Pittsburg mills. The cut is 30 feet deep and 800 feet long, but on account of the low dip (less than $2^{\circ} \mathrm{N}$.) it does not expose more than 40 feet of the drab-colored soft, highly fossiliferous fine grained sandstone. The rocks with the Eocene fossils appear to be higher both topographically and stratigraphically than those with the Miocene fossils, unless a fault intervenes of which no indication was seen. In view of the small number of species present and the imperfection of knowledge concerning the stratigraphic positions of western Oregon fossils it is quite possible that both of these collections come from the Oligocene, the fauna of which is known to be transitional from Eocene to Miocene.

NORTHWESTERN COLUMBIA COUNTY.

In the northwest corner of the township, near Marshland, about 60 feet of gray to white, fine-grained sandstone outcrops in two nearly equal massive beds separated by 8 inches of sandy shale. Eastward along the railroad from about 2 miles east of Marshland for 3 miles to Clatskanie Junction the rock is basalt, probably a flow, which reaches an altitude of over 300 feet on the steep hill south of the railroad. Eastward from Clatskanie to Mayger station the rock is also principally basalt, with a few poor exposures of sandstone and conglomerate apparently interstratified with the lava:

Near Clatskanie, and extending south to the top of the Nehalem divide, fairly good exposures of sedimentary rock appear to form an isolated mass without surface connection with outside areas, except possibly on the south, where there is little basalt. The stratigraphic relations are unknown, and Dall states that the fauna is peculiar and may be either Oligocene or a facies of the Miocene. A mile northeast of Clatskanie, on the wagon road to Mayger, at a bridge over a small stream, 8 feet of fossiliferous white chalky shale, probably either diatomaceous or tuffaceous, overlying 3 feet of sandstone, is well exposed. It dips at a very low angle, probably southeastward, and is cut by a large basalt dike on the west, and is bordered on the east by a mass of basalt which is exposed for more than 200 feet and which probably extends much farther. About 40 feet of light-gray, soft, thin-bedded, micaceous sandstone, which is exposed for about 4,800 feet south of the Clatskanie post office, contains an abundance of fossils (5328). Above this is 15 feet of white, very fine sandstone (diatomaceous or tuffaceous?) overlain by 20 feet of massive coarse sandstone, south of which is 15 feet of greenish fossiliferous sandy conglomerate (5333) cemented by lime. Two miles south of Clatskanie, at an altitude of about 200 feet, may be seen 15 feet of fine- 
grained greenish-gray thin-bedded sandstone, rich in fossils (5329). The fossils are matted together in concretionary "pockets," from a few inches to 2 feet in diameter and several feet long. The dip is between $4^{\circ}$ and $7^{\circ} \mathrm{W}$. The volcanic material in these beds and their general appearance are suggestive of the upper division of the Miocene, but of the 24 genera of fossils found in the four localities not one species was determined with certainty by Dall, although three are recognized with doubt. In the field the fossils were regarded as Miocene.

White tuffaceous or diatomaceous shale containing a few poor fossils (5335) was observed associated with basalt a mile east-southeast of Clatskanie on Benson's logging road.

\section{INDICATIONS OF OIL.}

All so-called oil seeps in Columbia County which were examined or from which samples were tested proved to be due not to oil but to other causes, most of the reports being based on the presence of iron scums on water. The reported localities which were not examined, because of the known geologic conditions or for other reasons, are (1) at Deer Island, which is in an andesite area; (2) at Batchelor Flat, 10 miles from Deer Island, reported by H. C. Gore, of Deer Island, but no samples submitted; (3) at Yankiton, 5 miles west of St. Helen, where C. F. Pearson, of Portland, reports that the well waters are rendered undrinkable by a substance resembling oil. These localities are all in the volcanic area along the eastern margin of the county, and the reports are submitted without comment to those who may desire to make further investigation. Five samples submitted from other localities in the same part of the county all showed iron hydroxide. No indications were seen or reported from the Nehalem Valley in this county, although the strata of the valley are more favorable to the occurrence of oil than the volcanic rocks farther east along Columbia River, where attempts to drill for oil seem useless. The supposed oil residue found in the town of Clatskanie is something else, probably weathered gum from evergreen trees. David T. Day examined a sample in the laboratory of the Geological Survey and pronounced it probably resin. The simple test of heating it and smelling the fumes emitted is sufficient to show that it is not an oil residue.

Petroliferous sandstone was observed by Diller ${ }^{1}$ on the head of Dairy Creek, in Washington County, a few miles south of the southern boundary of Columbia County. (See p. 76.) 


\section{WASHINGTON COUNTY.}

\section{GEOLOGY.}

No work was done in Washington County during the reconnaissance of 1910, and most of the following notes are abstracted from the report by Diller. ${ }^{1}$ on his work in northwestern Oregon. All the known fossil localities in Washington County are Miocene, so far as determinable, and it is probable that most of the sedimentary rocks in the county are of that age or are Oligocene, except possibly in the western margin of the county, where Eocene rocks might extend from their outcrops in Tillamook and Columbia counties. The soil is deep, and the rocks are almost completely decomposed under the rolling surface that characterizes the greater part of this county. Rocks, other than the hard igneous varieties, are scarce, except in the hills of the northern part of the county.

On Gales Creek, a mile above the post office, Diller observed 100 feet of dark shale dipping $40^{\circ} \mathrm{SE}$.

The divide between Nehalem River and Dairy Creek, especially the southern slope, is composed of Miocene strata. The lower strata appearing to the westward are chiefly shale, and the upper ones are for the most part sandstone, according to Diller.

On the West Fork of Dairy Creek both sandstones and shales occur. The latter are dark within but weather gray and when freshly broken have a decided odor of petroleum. The best exposure is in sec. 32, T. 3 N., R. 4 W., where a large landslide has occurred, exposing 250 feet of the shale. It is rather massive than fissile, and contains besides occasional casts of mollusks numerous small fragments of carbonized vegetal matter and minute bright scales of muscovite. Under the microscope it is seen to contain some volcanic material, also traces of Radiolaria and occasional green grains of glauconite. The fossils found here, Yoldia impressa Conr., Callista angustifrons, Lucina acutilineata Conr., with others not specifically determinable, are referred to the Miocene. The occurrence of bituminous light-colored shales in Oregon, containing radiolarian and volcanic fragments, is of such interest on account of their close resemblance to the Monterey shales of California. By the kindness of Prof. A. C. Lawson, of the University of California, who sent me a number of samples of the Monterey shale, I am able to compare them. Although those of Oregon are generally not so light colored, they are occasionally almost as white as chalk. Generally, however, there is no trace of bituminous matter about them, at least so far as one may judge from surface indications.

On the West Fork of Dairy Creek these shales dip gently eastward beneath the soft sandstones exposed lower down on the same stream. On the east fork of Dairy Creek (Emery Mill Creek) the sandstone is approximately horizontal and occasionally very fossiliferous. A coulée of basalt cascades over the side of the canyon 4 miles above Mountain Dale. A collection of fossils was obtained at this point and Dr. Dall recognized *** forms which he regarded as indicating a horizon well up in the Miocene.

Southward from Forest Grove an excellent exposure of dark-gray fossiliferous Miocene sandstone occurs at Boos's quarry, dipping to the northeast at an angle of from. 
$34^{\circ}$ to $41^{\circ}$. Fossils are abundant and evidently Miocene. On the Scoggins Creek road, a short distance above the road to Boos's quarry, a series of fossiliferous strata occur in essentially the same position as those at the quarry. ${ }^{1}$

\section{INDICATIONS OF OIL.}

The petroliferous radiolarian shale, mentioned by Diller in the preceding quotation, is the only oil indication known in Washington County. The comparison with the Monterey shale is interesting because it is thought by Ralph Arnold and other authorities on the California oil fields that the oil of southern California is largely derived from organic matter originally contained in the Monterey shale. Diller's description, however, does not indicate that there is any considerable mass of such shale in Washington County, and the writer believes from his own studies that shale with much diatomaceous or radiolarian material is rare in northwestern Oregon and is limited to thin partings.

No seeps or other oil signs in Washington County were reported to the writer.

\section{MULTNOMAH COUNTY.}

GEOLOGY.

The rocks of Multnomah County, so far as known, are almost entirely igneous. An insignificant amount of tuffaceous sandstone and shale is interbedded in places with the lava, and near Portland there are a few outcrops of completely rotted shale or clay. Marine Miocene rocks may occur near Portland, but only a few loose pebbles of marine fossiliferous rock have been found there.

The Heights, in western Portland, are composed of basalt and clay, the relations of which have not been determined. It is uncertain whether this clay is decomposed shale of the Miocene of Willamette Valley or is a later deposit. The tooth of a Pliocene llama or guanaco (Auchenia) is reported from an excavation for the Portland City reservoirs on the top of the Heights, and in gravel overlying the clay on the side of the hill a mastodon tooth was found in 1910. The clay reaches an altitude of over 500 feet on the hill, and similar material, but slightly more granular, like fine river silt, extends to the top of the hill, which has an altitude of about 650 feet (by aneroid). The clay is commonly thought to have been deposited beneath the Pleistocene water body which filled the Willamette Valley (the Willamette Sound of Condon ${ }^{2}$ ), but the camel tooth in the silty part and the possibility that some of the clays are interstratified with the basalt casts doubt on this mode of origin.

1 Op. cit., p. 471.

The Overland Monthly, vol. $\mathbf{i}$, pp. 468-473, 1871. Republished in The two islands, Portland, 1905, and in Oregon geology, Portland, 1909. 
At Bridal Veil, on Columbia River; the Pleistocene gravel reaches an altitude of over 1,000 feet. 'A remnant of the gravel, clinging to the south side of the gorge, may be seen on the wagon road which ascends the canyon wall from Bridal Veil. The gravel there contains pebbles of granite, coarse diorite, and schist, rocks which are foreign to the adjacent parts of the Cascade Mountains, and moreover the plunge structure in the gravel dips southward, indicating that it was deposited by the water of Columbia River.

An idea of the nature of the Quaternary material and of the underlying fresh-water formations associated with the lavas of western Multnomah County may be gained from the following log of a well drilled in prospecting for artesian water on the farm of W. S. Ladd, near Portland.

Log of well on farm of $W$. S. Ladd, near Portland, Oreg.

\begin{tabular}{|c|c|c|}
\hline$\cdot$ & $\begin{array}{l}\text { Thick- } \\
\text { ness. }\end{array}$ & Depth. \\
\hline & Feet. & Feet. \\
\hline Soil and fine sand. & 100 & 100 \\
\hline Sand, clay, and gravel ........... & 20 & 120 \\
\hline Gravel and basalt bowlders in san & 20 & 140 \\
\hline Bowlders, & 190 & 30 \\
\hline Sand, fine, and small basal tic pebbles. & 26 & 356 \\
\hline 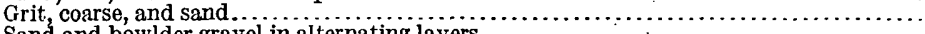 & 4 & 360 \\
\hline Sand and bowlder gravel in alternating layers . of fine sand containing fossil wood & $\begin{array}{r}45 \\
315\end{array}$ & 405 \\
\hline $\begin{array}{l}\text { Clay shale and olive-colored marl, wi } \\
\text { Grit, fine, sand, and gravel.......... }\end{array}$ & $\begin{array}{r}315 \\
10\end{array}$ & $\begin{array}{ll}720 \\
730\end{array}$ \\
\hline beds of fine soft sandst & 120 & 850 \\
\hline Clay shale and marl, with beds of fine & 150 & 1,000 \\
\hline 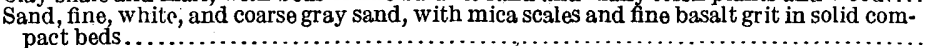 & 80 & 1,080 \\
\hline Shale, marl, and fine conglomerate, with fossil plants and a little sand. & 120 & 1,200 \\
\hline Basalt grit, coarse, ar & 50 & 1,250 \\
\hline Marl, fine, sandy, and shale with fossil plants. & 50 & 1,300 \\
\hline$\therefore \ldots \ldots \ldots \ldots$ & 400 & \\
\hline
\end{tabular}

The preceding log is given as reported by the drillers, because in the absence of samples it is not possible to verify: the names used for the different strata. So much basalt outcrops farther east that it is surprising that a well so deep should not enter it. Possibly the "granite" reported at the bottom is really volcanic rock, as the outcrops of granitic rocks are in southern Washington, over 40 miles northeast of Portland.

\section{INDICATIONS OF OIL.}

No oil indications have been found in Multnomah County, and it is not likely that oil ever will be discovered there, as the predominance of volcanic rock is highly unfavorable to its occurrence.

\section{CLACKAMAS COUNTY.}

GEOLOGY.

Clackamas County is almost completely covered by igneous rocks, and for this reason there is little chance of getting oil within its borders. Marine rocks of Oligocene or possibly lower Miocene age 
occur on Coal Creek and Butte Creek on the southern margin of the county. (See p. 90.) It is probable that the sandstone on the upper Molalla and the sandstones and thin limestones at Glad Tidings belong to the same group, which appears only in the bottom of valleys whose sides are composed of lava flows. At all the outcrops in which dips were obtainable, the inclination of the strata is eastward at low angles (about $5^{\circ}-10^{\circ}$ ).

The upper division of the Miocene outcrops at Scotts Mills, near the Marion County line, where it rests unconformably on basalt that is intrusive in the Oligocene and dips about $10^{\circ} \mathrm{W}$. The west dip is thought to be due to the fault which coincides with the western margin of the Cascade Mountains.

Fossils collected near Barlow, probably from the upper division of the Miocene of the Willamette Valley, have been sent to Prof. Condon. Somewhere in the same region Miocene fossils were collected $^{1}$ in 1851 by B. F. Shumard and John Evans, who describe the locality only as in "the Willamette Valley, a few miles south of Oregon City, Oreg." It is possible that these formations may be found elsewhere than under the small area of alluvium in the southwestern part of the county on which Barlow stands, and that they may not be cut by many igneous dikes, but the county as a whole is not a likely place to look for oil.

A prospect well is being drilled by the Home Oil \& Gas Co. about a mile south of Baker's bridge, 3 miles east-southeast of Clackamas, on the farm of L. Vierhaus, commonly known as the "Hess place." When visited in 1910 the well was drilling at a depth of 535 feet, and it was later abandoned at a depth of about 1,200 feet.

Log of well of the Home Oil \& Gas Co.

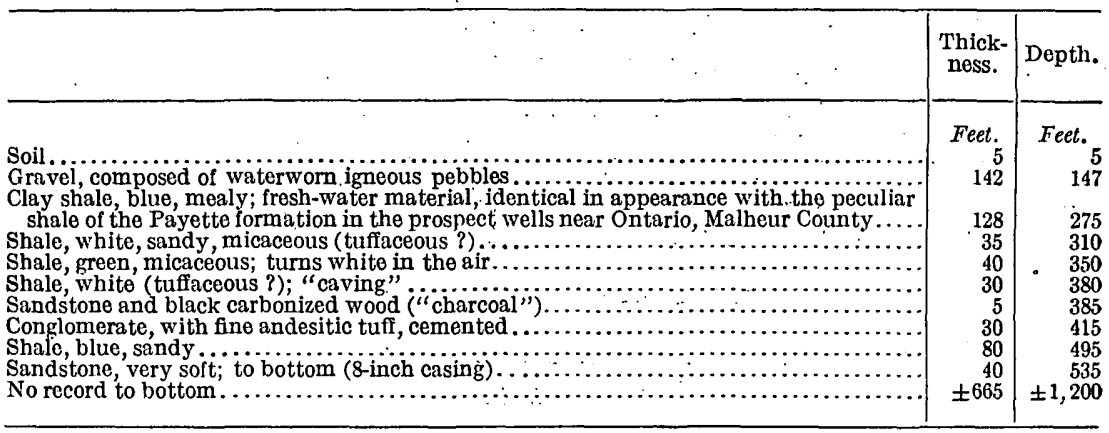

No traces of oil or gas had been encountered. The rocks of the locality are largely volcanic: Most of the hills are composed of andesite or basalt, and in the stream beds a few exposures of sedimentary rock of fresh-water origin were seen. Two miles east-southeast of Clackamas about 20 feet of nearly horizontal gray sandstone beneath 
25 feet of gravel is exposed in a bluff of Clackamas River. One mile east of the preceding locality 10 feet of gray tuffaceous. sandstone is overlain by 5 feet of andesite tuff and capped by 3 feet of gray micaceous sandstone. The dip is $18^{\circ} \mathrm{W}$.

Beyond the fact that the sedimentary rocks in this part of the county are Tertiary, their age is unknown.

The strata overlying the marine Oligocene rocks on Coal Creek, in the southern part of the county and near Wilhoit Springs, are coalbearing, but the coal beds are thin.

\section{INDIOATIONS OF OIL.}

No reports of indications of oil or gas in the county have been verified. Several samples of substances thought to be oil have been examined and found to contain none.

L. H. Newman of Oregon City reports that he-has found a "brightyellow gelatine," which he believes to be an oil residue, in fissures in shale at a sulphur spring about half a mile east of Oregon City. No sample has been submitted.

\section{YAMHILL COUNTY.}

GEOLOGY.

GENERAL FEATURES.

The rock of the western part of Yamhill County is largely igneous, mostly intrusive basalt and diabase, with a few large masses of coarsegrained rocks, such as dolerite and probably diorite. East of the principal range of igneous rock is a broad belt of shale, which underlies most of the open valley near North Yamhill, McMinnville, and Sheridan, and extends into Polk County on the south. Above this shale, which contains small beds of sandstone, is a series of marine and fresh-water sandstones, with thin or dirty coal beds, that outcrops between North Yamhill and Newburg. Similar rock is reported from the Yamhill Mountains in the southeast corner of the county, but was not examined. The sandstones are Miocene, and the underlying shales are probably lower Miocene and Oligocene.

NORTHEASTERN YAMHILL COUNTY.

The Newburg Hills, on the northeast border of the county, are mainly basalt, which is well exposed between Frank and Springbrook stations, on the Newburg division of the Southern Pacific Railroad. The basalt hills trend northwest and southeast, making the divide between the Tualatin and Chebalem valleys for about 12 miles. Sandstone containing thin coal beds is said to outcrop along the north side of the hills. On the south side, in the Chehalem Valley, Miocene rocks outcrop very imperfectly at a few places, and a few fossils have been obtained from a depth of about 50 feet in a well on the farm of 
Mrs. Hellen Follett, 4 miles northwest of Newburg. The few determinable dips in this neighborhood are $6^{\circ}-12^{\circ} \mathrm{W}$. or NW. One mile west of the well a large basalt dike trends N. $45^{\circ} \mathrm{W}$. and dips southwest, and near by are exposures of gray and white foliated shales. Erratic bowlders of granite, probably dropped from ice floating in the Willamette Sound ${ }^{2}$ occur on the hillsides up to an altitude of about 400 feet.

A bed of hard gray sandstone, dipping $7^{\circ}-10^{\circ}$ E., outcrops $1 \frac{1}{2}$ miles northwest of the preceding locality and is overlajn on the east by light-gray foraminiferal shale. About 15 feet of the sandstone is exposed. One-half mile farther northwest the dip is $8^{\circ} \mathrm{E}$. in sandy gray shale containing Foraminifera, at the top of which is another 15 -foot sandstone that is fine grained, white, and calcareous and $\operatorname{dips} 10^{\circ} \mathrm{E}$.

The best exposure in the region is an outcrop of sandstone on the road to North Yamhill, 2 miles west of the preceding locality and about 2 miles southwest of Dewey. The top bed of sandstone is at least 40 feet thick and is underlain by 12 feet of conglomerate, beneath which is 50 feet of sandstone, all barren of fossils, dipping $9^{\circ}-10^{\circ} \mathrm{E}$. and striking about N. $5^{\circ}-15^{\circ} \mathrm{E}$. The conglomerate is composed largely of small waterworn pebbles of various kinds and much finer angular basaltic fragments, probably volcanic scoria. The only fossil known from this neighborhood is a cast of Paradione found by C. A. Deach in sandstone containing coal signs, $4 \frac{1}{2}$ miles northeast of North Yamhill, in sec. 25, T. 2 S., R. 4 W. The rocks from this place eastward to Newburg are the highest sedimentary strata seen in Yamhill County and probably belong to the upper division of the Miocene. The apparent thickness of the sandstone and shale between Newburg and Dewey is 1,000 feet or more, but the total thickness of the formation is probably much greater, as the rocks may continue far eastward beneath the alluvium of the Willamette Valley.

The character of the lower part of the formation is indicated by the following log of a well drilled by the Portland Coal \& Development Co., in prospecting for coal, near the southwest corner of the SE. $\frac{1}{4}$ SE. $\frac{1}{4}$ sec. 25, T. 2 S., R. 4 W. The elevation is about 300 feet above sea level.

Log of prospect drill hole 4 miles east of North Yamhill.

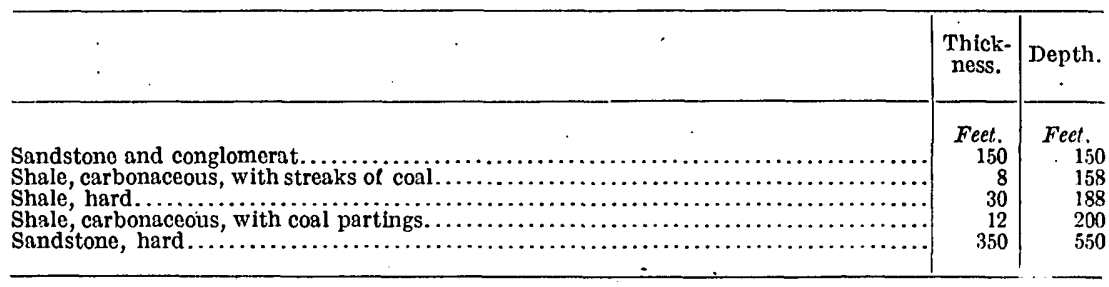

1 Condon, Thomas, Oregon geology, Portland, 1909.

$\left.47196^{\circ}\right\lrcorner$ Bull. $590-14-6$ 
The coal beds of this formation are too thin and too dirty to be considered of economic value. In the upper carbonaceous shale of the preceding section the following coal is reported by Deach:

Section of coal bed in well of the Portland Coal \& Development Co.

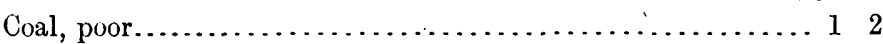

Shale, white, hard................................... 6

Coal, good..................................... 4

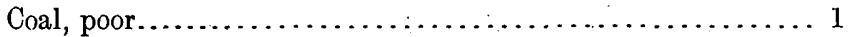

Hard rock with thin coal partings.......................... 14

44

West from the preceding localities : to North Yamhill there are a few indications of shale, mostly in farm wells. Two miles southwest of the coal prospect a road cut exposes the following rock, which dips $12^{\circ}-15^{\circ} \mathrm{E}$. and strikes probably N. $10^{\circ}-15^{\circ} \mathrm{E}$ :

Section in road cut 2 miles southwest of coal prospect.

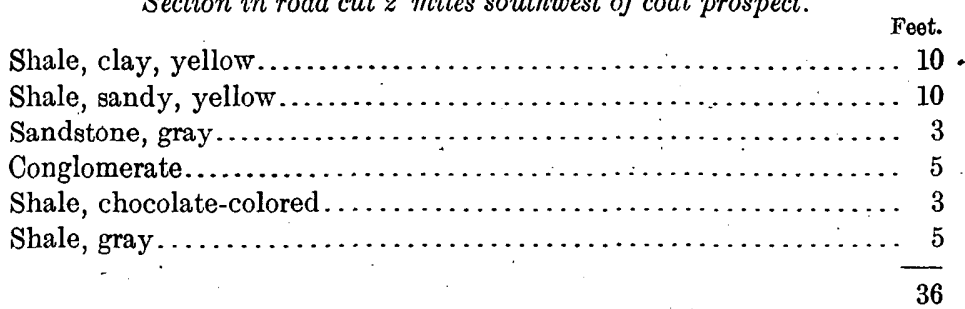

One mile farther west wells on the farm of Clarence Laughlin furnish the following section:

\section{Section of well on Laughlin farm.}

Feet.

Shale, dark, weathers yellow.......................... 25

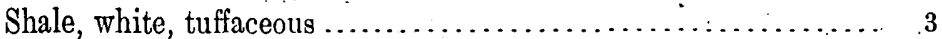

Shale, gray to white................................ 50

Shale, blue.................................... 50

128

The shale is well exposed in large quarries which are worked for pottery clay one-fourth mile west of North Yambill, where there are two pits with divergent dips, suggestive of an anticline. In pit No. 1, on the north side of the wagon road, the strike is N. $40^{\circ}$ W. and the $\operatorname{dip} 12^{\circ}-20^{\circ} \mathrm{NE}$., and in pit No. 2 , on the south side of the road, the strike is the same, but the dip is $8^{\circ}-10^{\circ} \mathrm{SW}$. This anticline appears to be only a local fold and is cut by one small dike of basalt about 200 yards southeast of the clay pits. As indicated by squirrel burrows and wells the shale, with a few tuffaceous layers; continues eastward to a hill less than a mile northeast of the town, where there is an imperfect outcrop of overlying sandstone. The shale is mostly dark in color when fresh, but weathers to various shades of brown, 
yellow, light gray, and sometimes white. Most of the white layers are thought to be tuffaceous, but have not been examined microscopically. Indeterminable crushed fossils were found in both clay pits.

The character of a small part of the shale is indicated by the log of a well drilled for water by T. W. Perry at the Southern Pacific Co.'s station in North Yamhill. A little salty water is reported in the well at a depth of 325 feet.

Log of well at railroad station, North Yamhill.

\begin{tabular}{|c|c|c|}
\hline$\therefore$ & $\begin{array}{l}\text { Thick- } \\
\text { noss. }\end{array}$ & Depth. \\
\hline 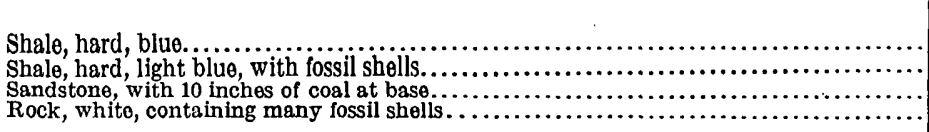 & $\begin{array}{r}\text { Feet. } \\
48 \\
340 \\
25 \\
85\end{array}$ & $\begin{array}{r}\text { Feet. } \\
48 \\
388 \\
413 \\
498\end{array}$ \\
\hline
\end{tabular}

Between North Yamhill and Fairdale only basic igneous rocks were seen, but about 4 feet of hard sandy blue shale outcrops in the bed of the creek at the latter place. Its strike is N. $70^{\circ}-80^{\circ} \mathrm{E}$. and its dip $10^{\circ}-12^{\circ} \mathrm{SE}$. Near the wagon bridge at Fairdale sandstone is poorly exposed between outcrops of the more abundant shale. These rocks must lie well below those east of North Yamhill, and are all older than any of the numerous igneous bodies whose relations could be determined. Four miles northwest of Fairdale the shale dips $10^{\circ} \mathrm{NE}$. or $\mathrm{E}$. and is cut by a dike of diabase.

$$
\text { SOUTHERN YAMHILL COUNTY. }
$$

At McMinnville the rocks are almost completely covered by the deep soil which fills the wide rolling valley of Yamhill River. In the bed of the river, abcut one-fourth mile below the railroad bridge, about 15 feet of soft coarse sandstone is exposed, which dips $3^{\circ} \mathrm{NW}$. The sandstone contains a few small waterworn pebbles of igneous rocks. The rocks beneath the valley are thought to be largely shale, as at North Yamhill, and are best shown by the following log of the city water well, which was being drilled in sec. 13, T. 4 S., R. 5 W., 4 miles northwest of McMinnville:

Log of city water well near Mc Minnville.

\begin{tabular}{|c|c|c|}
\hline$\therefore$ & $\begin{array}{l}\text { Thick- } \\
\text { ness. }\end{array}$ & Depth. \\
\hline 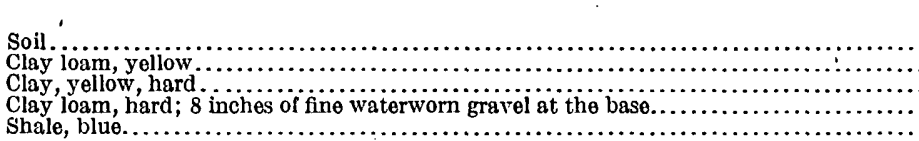 & $\begin{array}{r}\text { Feet. } \\
2 \\
4 \\
7 \\
12 \\
275\end{array}$ & $\begin{array}{r}\text { Feet. } \\
2 \\
6 \\
\quad 13 \\
25 \\
300\end{array}$ \\
\hline
\end{tabular}


The upper 25 feet of strata in this well are probably Quaternary and resemble the deposits made in the "Willamette Sound " in early Quaternary time.

For more than 10 miles southwest of McMinnville the visible rocks are mostly igneous, except a few outcrops of hard-baked shale in the creek valleys, which dip eastward at low angles and are closely bordered on the east and west by ridges of basalt and diabase. On Dawson Creek, 6 miles northwest of McMinnville, are exposures of basic diorite. On the road to Sheridan weathered shale was seen at a few localities, besides the ever-present basalt. In Sheridan, and extending about half a mile east along the south side of a hill, there are numerous exposures, mostly clay shale, with many sandy layers and a few thin beds of sandstone about a foot thick. One mile east of Sheridan the strike is N. $40^{\circ} \mathrm{W}$. and the dip $15^{\circ} \mathrm{SW}$. At the city reservoir half a mile north of Sheridan the strike appeared to be $\mathrm{N} .15^{\circ} \mathrm{E}$. and the dip $85^{\circ} \mathrm{NW}$., but this was probably caused by a local disturbance due to an igneous intrusion or to sliding. Along the river for a mile west of Sheridan, several exposures of shale, possibly the same formation but dipping $12^{\circ}-20^{\circ} \mathrm{NE}$., may be on the west limb of a syncline, the axis of which probably passes through Sheridan, where there are several dikes of basalt; but the two sets of dips may indicate equally well that there are two fault blocks inclined toward each other at this place. The repeated evidence of minor faults in this entire region makes it hazardous to assume that there are unbroken folds where the dips commonly would be so interpreted. Immediately above Sheridan Yamhill River exposes 11 feet of blue clay shale dipping $20^{\circ} \mathrm{NE}$., and half a mile above Sheridan about 25 feet of soft gray sandstone, striking N. $40^{\circ} \mathrm{W}$. and dipping $18^{\circ} \mathrm{NE}$., is underlain by blue shale with hard calcareous layers dipping $14^{\circ}$ $\mathrm{NE}$. The same shale continues half a mile farther up the river, dipping $12^{\circ}-14^{\circ} \mathrm{NE}$. In this section there is about 1,000 feet of rock, mostly shale, which is thought to be Oligocene or lower Miocene, although no fossils were found at this place. "The shale is locally altered into a hard flinty rock by the diabase and basalt.

The next exposure, 3 miles west of the last, is in the deep cut of the Pacific Coast Face Brick Co., half a mile west of Willamina post office, where there is about 70 feet of shale, mostly dark clay shale but of variable character. Some layers are black and carbonaceous and turn white when burned, and some are dark green (glauconitic?) and burn red. There is also a little light-gray or white shale, with soapy feel, which is mixed with the black carbonaceous shale to make brick. Calcareous concretions from this excavation furnished a small collection of fossils which were not specifically determinable, bit which indicate probably an Oligocene or lower Miocene age. The structure is irregular, probably from creeping movements downhill, 
a sort of slow landslide which is common in the clay rocks of western Oregon dtring the wet season. The shale is slickensided on most of the joints and bedding planes, and the dip is irregular, and in various directions, so that in spite of the excellent exposure the normal inclination of the rock cor:ld not be determined. One-half mile farther east, near the bridge in Willamina, a thin bed of sandstone in the shale in the bed of the creek strikes N. $80^{\circ}$ E. and dips $12^{\circ} \mathrm{N}$.

Seven miles north of Willamina, near the ranch of $R$. L. Booth, in sec. 1 , T. 5 S., R. 7 W., and northward to sec. 26 , T. 4 S., R. 7 W., there are extensive exposures of coarse-grained igneous rock, probably diorite. On the southeast side of the igneous mass, in sec. 1, Willamina Creek has undercut a little bank in which about 25 feet of hard brown slaty shale may be seen, striking N. $80^{\circ} \mathrm{W}$. and dipping $20^{\circ} \mathrm{S}$. The same rock with similar dip was also observed in sec. 36 , T. 4 S., R. $7 \mathrm{~W}$. Its age is unknown, but it does not resemble the Tertiary shale seen at other places, although it may possibly be the same rock altered by contact metamorphism in an unusual way. On the same creek, at Mr. Booth's house, a short distance below the slaty shale, is an outcrop of conglomerate composed of waterworn igneous pebbles, dipping at a low angle southward, below which for 6 miles to Willamina there are a few poor outcrops of shale and many of basalt.

On the road from Dolph to Willamina, in the southwestern corner of the county, there are several outcrops of shale and basalt. At Dolph a dip of $20^{\circ} \mathrm{SE}$. was noted in clay shale. Two miles east of Dolph the dark-gray clay shale dips about $15^{\circ} \mathrm{NE}$., and similar shale $3 \frac{1}{2}$ miles from Dolph appears to dip about $5^{\circ} \mathrm{SE}$. Seven miles from Dolph thin-bedded micaceous clay shale dips $8^{\circ} \mathrm{SE}$. For 8 miles east of the last point there are no exposures along the wagon road other than a few outcrops of basalt and some imperfect outcrops of rotted shale. If the southeast dips continue throughout this distance or even through the first 7 miles, without much repetition by folding or faulting in the concealed spaces, it would indicate a thickness of sereral thousand feet of shale, but it is probable that there is much repetition of strata and that the true thickness is only a small fraction of what it appears to be.

On the same road 15 miles from Dolph and 2 miles west of Willamina outcrops of sandstone and shale in bluffs of the Yamhill River dip northward at low angles.

The shale near North Yamhill, McMinnville, and Sheridan appears to form part of a broad shale belt that extends along the east side of the Coast Range as far south as Monmouth and Falls City in Polk County, beyond which, in Benton and Lane counties, it is absent or is represented by the fresh-water coal-bearing formation that underlies the marine Miocene of the upper valley. The shale is thought to be 
of lower Miocene age and possibly to include some Oligocene at its base. Poorly" preserved fossils, resembling species common in the Astoria shale, were found in the clay pit of the Pacific Face Brick Co. at Willamina. Diller ${ }^{1}$ reports "Pseudamusium peckhami (?) Gabb and other Miocene forms" in calcareous nodules in the shale at the south end of Wapato Lake, north of North Yamhill. The dip of the shale in Polk County would carry it beneath the fossiliferous lower Miocene sandstones that outcrops at Home's ranch, near Crowley. The shale is probably equivalent in a general way to the Astoria shale of Clatsop and Columbia counties, but the general absence or poor preservation of fossils renders correlation uncertain.

STRUCTURE.

The structure of the sedimentary rocks of Yambill County is so greatly affected by igneous intrusions that it is not safe to assume the presence of anticlines wherever opposing dips occur. Detailed work and the examination of all shallow wells and other excavations are necessary to determine the true nature of these doubtful structures. There is probably an anticlinal axis between the two clay pits at North Yamhill. (See p. 82.) The low northwest dip found in the river bank at McMinnville suggests an anticline somewhere east of that place. Similar evidence suggests an anticline in the shale 1 to 2 miles east of Willamina and another anticline more than 2 miles east of Sheridan. Igneous intrusions are present near all these localities and may be the cause of part of the anticlinal appearance of the rocks.

In general, the greater part of the county is underlain by eastdipping rocks, and the youngest formations are those farthest east, namely, the lavas and underlying coal-bearing sandstone of the Newburg Hills. The older rocks farther west are mostly shale, greatly affected in -structure and induration by the many igneous bodies, which make nearly all the hilltops of the western half of the county. All of these rocks are thought to be post-Eocene, as no Eocene fossils nor any strata resembling the Eocene of northwestern Oregon have yet been found in Yamhill County.

\section{INDICATIONS OF OIL.}

No reliable indications of oil were found in Yamhill County, although many so-called "seeps" were examined and found to be of other origin. The published report that traces of oil were struck at 150 feet in drilling the city water well at McMinnville proved to be a mistake, according to the samples submitted, which contained no oil.

Two wells were drilled in 1902 on the farm of Mrs. Helen Follett, 6 miles west of Newburg, by A. C. Churchill and others. The first 
well is 1,240 feet deep and the second, only 10 feet away, is 1,287 feet deep. It is reported by some that natural gas was struck in these wells, but Mr. Churchill states that the only gas was a small trace encountered at about 1,100 - feet; which "smelled .. like a a sulpliur spring" (hydrogen sulphide) and which "would not burn.". He observed no oil on the water. No accurate log of the wells is available, but Mr. Churchill reports that the first 600 feet was drilled mostly in sandstone, with some thin shale beds. One bed of sandstone about 100 feet thick contained many fossil shells. Below a depth of 600 feet the rock was nearly all shale. A little salt water was encountered near 600 feet.

An odorless inflammable gas bubbles from the mud bottom of a mineral spring in the bed of a ravine near B. F. Hartman's house in McMinnville. To all appearances this is ordinary marsh gas, and it would not be mentioned here but for the peculiarly bitter water through which the gas escapes. According to a commercial analysis made for Mr. Hartman, the water contains 429 grains of solid matter dissolved in each pint, nearly all of which (404 grains) is sodium sulphate with small amounts of magnesium and calcium sulphates and sodium chloride. Water like this is not rare at the surface in arid regions, but in the humid belt of the northwest coast it can not be derived from the passage of meteoric water through the soil and shallow rocks and must come from deeper sources. The spring is not noticeably warm. The unusual abundance of gas in salty springs has been remarked at many places, but the cause of this association is not known. The formation of the gas in the mud bottom of the spring may be promoted by the presence of salt in the water, in which case such springs have no significant bearing on the presence of gas in the underlying strata; or the gas may have been brought up by the water from a deeper source. Without other indications and without knowledge of the rock structure the writer can not encourage those who plan to drill near such springs.

William Heyser reports that the water from a 70-foot well, at his home in Carlton, is not drinkable and that an oil scum appears on it after standing overnight. . This locality was not visited, and the report could not be verified by samples.

It is reported that preparations to drill a test well in sec. $32, \mathrm{~T} .2 \mathrm{~S}$., R. 4 W., are being made by Richard Baird, of Yamhill.

\section{POLK COUNTY.}

GEOLOGY. . .

Polk County, like Yamhill County, which it borders on the south, reaches from Willamette River to the summit of the Coast Range. The valley part is largely alluvium with a few low volcanic hills, and 
the western part a rough dissected region of older Tertiary rocks, both sedimentary and igneous. No work was done in the higher mountains during this reconnaissance.

The foothill region of the Coast Range and the border of the valley between Falls City and Monmouth is mostly shale, with small exposures of sandstone, all dipping eastward wherever seen, but all cut by igneous rocks, which render the thickness and sequence uncertain.

The shale at Falls City is locally baked and is intruded by diabase and basalt, which make the falls of the Luckiamute River at that place. Hard slaty shale beneath the Falls City bridge strikes N. $80^{\circ}$ E. and dips about $10^{\circ} \mathrm{S}$. A little coal was found on the hillside at this place, but the prospect has caved in and covered the coal bed, which is reported to be too thin to work. The shale outcrops at many places on the railroad from Falls City to Dallas, at all places dipping eastward or southeastward. About 3 miles southwest of Dallas is a quarry in a fossiliferous sandstone that strikes N. $20^{\circ} \mathrm{E}$. and dips $15^{\circ} \mathrm{SE}$. The rock is light gray, massive, fine grained, and calcareous. The total thickness probably exceeds 50 feet. To the east a few exposures of overlying shale occur at intervals for about a mile, all dipping $5^{\circ}-15^{\circ} \mathrm{SE}$.

The same clay shale outcrops on La Creole Creek, one-half to $1 \frac{1}{2}$ miles northwest of Dallas, striking N. $10^{\circ} \mathrm{W}$. and dipping about $10^{\circ} \mathrm{E}$. Westward they are succeeded by a large mass of basic igneous rock. Two miles northeast of Dallas some soft white shale of very low specific gravity, probably either tuffaceous or diatomaceous, strikes N. $40^{\circ} \mathrm{W}$. and dips $12^{\circ} \mathrm{NE}$. Shale was seen 4 miles northeast of Dallas, dipping at a low angle eastward.

The rocks at the preceding localities are all more or less similar clay shale except the white shale northeast of Dallas and the bed of sandstone at the rock quarry. They are thought to belong to one formation, mostly. shale, the same that outcrops at Sheridan, Willamina, McMinnville, and North Yamhill. The shale is probably lower Miocene, but the fossils are too poorly preserved to permit close determination of their age. Better fossils, representing horizons low in the Miocene, occur in the overlying sandstones mentioned below and give satisfactory evidence that the shale is iower Miocene or older, probably in part Oligocene. The shale of Polk County differs from the typical Astoria shale of Clatsop County in the absence of greensand and.Foraminifera, the scarcity of fossils and concretions, and the greater abundance of sand. Its approximate correlation with the Astoria shale is, however, not improbable.

Miocene sandstone and some shale outcrop about 8 miles northeast of Dallas, dipping eastward away from the localities described in the preceding paragraphs. The best exposures make a strong ledge that may be followed over a mile along a hillside on the farm 
of A. M. Home, 3 miles south of McCoy. The strata dip about $10^{\circ} \mathrm{E}$. and include the following beds:

Section 3 miles south of McCoy.

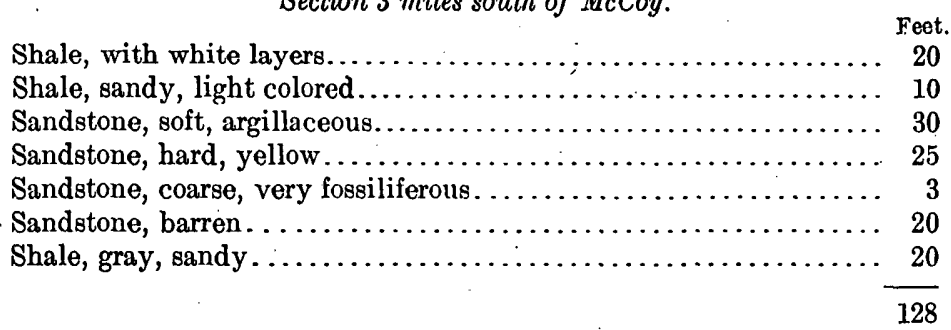

Dall referred the first collection ${ }^{1}$ of fossils from this locality to the Oligocene with doubt, but he refers to the lower Miocene the larger collections made by the present party from the same beds. This is the most fossiliferous locality of the lower division of the Miocene that has yet been found in the Willamette Valley.

Fossils found in sandstone about 5 miles southeast of the preceding locality, near Eola, not more than a few hundred feet above the horizon near $\mathrm{McCl}$, are somewhat different and probably belong in the upper division of the Miocene. These fossils were collected by Thomas Condon. More recently A.J. Collier has found fossils which represent the same beds in the vicinity of Halls Ferry at two localities $5 \frac{1}{2}$ and 6 miles southwest of Salem, both of which are referred. to by Dall. ${ }^{2}$

\section{INDICATIONS OF OIL AND GAS.}

A small flow of gas is reported to have been struck between 1,400 and 1,500 feet in a well drilled by the Oregon Oil \& Pipe Line Co., 3 miles southwest of Dallas, Oreg. An accurate log is not available, but the drill is said to have passed through dark-colored shale with thin-bedded sandstone near the bottom, in which the gas was encountered. The flow is said to have been sufficient to maintain a flame 2 feet high out of a 10 -inch casing for several days. No gas was escaping at the time the well was visited in 1910, but residents of the vicinity corroborate the report.

The Dallas Oil Co. is preparing to drill in the same vicinity.

Veinlets of brilliant black, solid, brittle, hydrocarbon, one-eighth to one-fourth inch thick, have been found by H. B. Brophy on his farm near Eola, $4 \frac{1}{2}$ miles west of Salem. The specimens submitted for examination are in sandstone that probably belongs to the lower part of the upper division of the Miocene, which seems to cover most of that neighborhood.

Many "seeps" are reported from this county, but all that were examined either by testing samples submitted or by visiting the localities proved not to be oil but mostly iron scums on water. 
Polk County, east of the Coast Range, contains fewer igneous intrusions than the counties farther north; and to this extent the geology is more favorable to the occurrence of oil or gas. "No anticlines were seen.

\section{MARION COUNTY.}

GEOLOGY.

Marion County contains few exposures of sedimentary rock in its western or valley part, which is the only place that offers any chance of oil. East of the valley at Butte Creek and along the low front of the Cascade Mountains a few exposures of Miocene sandstone are bordered on the east by igneous rocks, among which are exposures of marine Oligocene or possibly lower Miocene sandstone and shale, overlain by fresh-water coal-bearing strata. (See p. 79.) Freshwater sediments, almost wholly of volcanic material but containing traces of coal, are interstratified with the lavas at several places in the eastern part of the county. At the falls of Silver Creek, near Argenti, these rocks dip eastward at a very low angle, not more than $4^{\circ}$.

In the open valley part of Marion County there is much basalt in horizontal sheets. The sheets near Turner appear to be surface lava flows, but whether they are intrusive sills or surface flows has not been generally determined. Mount Angel, in the northeastern part of the county, is a residual mass of basalt, probably intrusive.

Fossiliferous Miocene sandstone has been found at Halls Ferry, $5 \frac{1}{2}$ miles southwest of Salem, by Collier. ${ }^{1-}$ The fossils appear to belong to the upper division of the Miocene, and this is also true of the fossils of the highest strata of the Eola hills, across the river in Polk County, where Condon obtained many fossils. The sandstone in the northern part of the same hills belongs to the lower division of the Miocene. All of these rocks dip $10^{\circ}$ to $15^{\circ} \mathrm{E}$. Two miles east of Independence a doubtful dip of $30^{\circ}$ (?) E: was observed.

B. F. Shumard ${ }^{2}$ described a fossil Leda collected by John Evans from Miocene "dark-gray siliceous limestone, at Brooks's lime quarry, Willamette Valley, 5 miles north of Salem, Oreg. Ter."

\section{INDICATIONS OF OIL.}

No structures favorable to the accumulation of oil and no oil seeps or other indications are at present known in Marion County. It would be possible to get oil in a deep well only in the western part within 12 or 15 miles of Willamette River, and even there much care would be necessary to select sites that would be free from the intèrference of igneous bodies. 


\section{LINN COUNTY.}

GEOLOGY:

The geology of Linn County is similar to that of Marion County, which it borders on the south. The greater part of the county lies on the western slope of the Cascade Range, where the rocks are almost wholly volcanic. Only in the western fourth of the county is it feasible to sink wells, and the chances of striking oil at any place are remote although not impossible.

The basalt sheets so common in the valley in Marion County are replaced by volcanic necks in Linn County. These cores of igneous rock, including Knox, Peterson, and other buttes, rise above the valley alluvium, like rocky islands in a green sea. Whether or not the strata beneath the unconsolidated valley fill is broken by many dikes can not be determined, but the presence of so many volcanic cores justifies the inference that many dikes cut the strata and injure their efficiency as possible oil reservoirs.

Marine Eocene sandstone has been found near Granger, 5 miles west of Albany, and at other localities in Benton County. The fossiliferous Eocene sandstone opposite Albany was first found by Condon and announced by White. ${ }^{1}$ In Linn County these rocks, if present, are covered by alluvium.

Oligocene rocks may also exist beneath the alluvium, but they have been seen only in a railroad cut between Lyons and Kingston, where a dark leaf-bearing shale, associated with fine fragmental volcanic material, resembles the Oligocene strata seen on Coal Creek in southern Clackamas County and in the Coburg Hills of Lane County. The dip is eastward at a low angle.

Marine rocks of the upper division of the Miocene have been found at Twin Buttes and through the hills southward to West Point, beyond which they continue along the base of the Coburg Hills in Lane County. At all these localities the dip is $5^{\circ}-10^{\circ} \mathrm{E}$.

Miocene sandstone and sandy shale are exposed at a few localities on Peterson Butte, 3 miles southwest of Lebanon, especially on the west side of the butte, where the small fossil fauna found is thought to represent a phase of the upper division of the Miocene. The following species from this place were determined by Dall: ${ }^{2}$

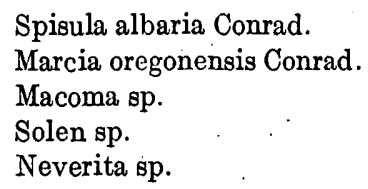

Venericardia castor Dall. Cardium cf. ciliatum Fabricius. Fusinus sp. Crepidula sp.

The Venericardia and Cardium have not been found in the upper division of the Miocene as exposed near Eugene and Springfield, but 
- the same species of Venericardia occurs in somewhat lower rocks on the Owen farm on Spencer Creek in Lane County.

In low hills northeast of Lebanon there are rocks resembling the sandy shale of the Miocene, but no fossils were found in them. No other outcrops of marine strata are known to the writer.

\section{INDICATIONS OF OIL.}

No reported indications of oil or gas in Linn County have been verified, but a few have been examined and found not to be oil or gas. Most of them are not thought worthy of mention here.

Frank Lines, of Albany, writes that there is an oil seep on his farm at the east base of Knox Butte, 6 miles east of Albany. No examination has been made to determine whether the scum observed is oil or the common film of iron oxide.

J. V. Pipe, of the same city, also believes he has found indications of oil in Linn County. The report was not verified.

\section{BENTON COUNTY.}

GEOLOGY.

Benton County is underlain principally by Eocene rocks, prevailingly sandstone, which contain volcanic material in many places. The Eocene is bordered on the east by a narrow strip of Miocene strata, soft sandstone, and sandy shale, which also contain volcanic material. The Miocene is seen at few places, being largely concealed by the alluvium which covers the broad valley on the east. The dips along the margin of the Coast Range are prevailingly eastward. Within the range the dips are exceedingly irregular, and the notes at hand do not indicate any general or well-pronounced structures.

Diller ${ }^{1}$ examined the volcanic material at Vineyard Hill, 4 miles north of Corvallis, and noted its similarity to the Eocene sedimentary rocks of the northwestern counties. The fossils at Vineyard Hill are not distinctive, but shale near Howe's, immediately east of the hill, yielded characteristic Eocene fossils. The volcanic sediments on Marys River do not reach the summit of the Coast Range, but their limits are not determined. Similar strata, barren of decisive fossils, occur at Monroe.

Fossiliferous Eocene shale dipping eastward at a low angle occurs at Benson's farm, 5 miles north of Corvallis. Fossils were also obtained in more sandy layers near Scott's, Cooper's, and Newton's farms, a few miles southwest of Corvallis. The general strike is approximately north and south and the dip easterly. Thirty feet of sandstone, near Rogers, in sec: 27, T. 13 S., R. 6 W., yielded Venericardia planicosta Lamarck, the most characteristic fossil of the Eocene 
epoch. The sandstone dips about $20^{\circ} \mathrm{N}$. At the foot of Coon Hill, .4 miles farther east, beyond a large igneous intrusion, the same fossil was found in a soft sandstone, which there has the more normal north-south strike and dips west at a low angle. Variations of this kind in dip and strike are numerous throughout western Oregon and in many places are due to the influence of igneous bodies.

Near Monroe Eocene fossil localities, all in massive sandstone, are cut by igneous intrusions. The largest intrusion, probably a sill of diabase, makes the high ridge about 2 miles southwest of the town. It dips $5^{\circ}-10^{\circ} \mathrm{E}$.

Near Dusty, in the same township, the Eocene sandstone outcrops in low inconspicuous mounds, in a rolling country that is a common feature of the western margin of the Willamette plain. The sandstone is fossiliferous and dips about $10^{\circ} \mathrm{E}$.

According to Diller," "In Long Tom Creek, at Monroe, a low arch of tuffaceous sandstone is exposed and appears to run under the strata of the hills a short distance to the westward. They dip gently eastward, and the Eocene beds must lie some distance to the west." Diller's opinion is confirmed by the finding of Eocene fossils in sandstone at Dusty. The contact of the Miocene and Eocene is unconformable, as shown in the bed of a small creek about 2 miles southwest of the quarry.

Sandy Miocene shale outcrops in places along the wagon road south of Monroe, through T. $15 \mathrm{~S}$. and in northern Lane County, where it has been studied more carefully.

The Eocene outcrops in the low hills near Granger, on the Corvallis \& Eastern Railroad, about 5 miles west of Albany. This locality and also that in which the Eocene is exposed near Benson's and Howe's farms, a few miles farther west, lies several miles east of the general trend of the Eocene-Miocene contact, suggesting an uplift. The imperfection of the exposures prevents the determination of the actual structure, but it is most likely that a fault of considerable throw runs northeastward along the south side of the hills. Cross structures normal to the general trend of the Coast Range are probably well developed, for the rocks in the western part of the county strike east and west and many igneous intrusions trend in the same direction.

Sandstone and shale resembling the Eocene strata farther east reappear near Philomath, with variable dip due in part to the presence of igneous bodies. Between Philomath and the summit of the Coast Range on the Elk Creek road there are no good exposures of sedimentary rocks.

Marys Peak, 10 miles southwest of Philomath, is the highest point in the Coast Range north of Umpqua River. It is a large mass of fine-grained diorite surrounded by Eocene sedimentary rocks, which 
it has intruded. The sediments are tuffaceous and sparsely fossiliferous, but the contact metamorphism makes it nearly impossible to recognize many of the fossils obtained close to the mountain. Farther west, however, on the head of Elk Creek, an Eocene Turritella was found. The high flat-topped spur or terrace on the northwest side of the summit of the peak is composed of very hard flinty shale, containing fossils which have been almost destroyed by metamorphism.

Forest Peak (north of Marys Peak), Buck and Green peaks to the south, and Prairie Mountain in the southwest corner of the county are all composed of more basic igneous rock. Prairie Mountain appears to be a very thick sill or laccolith of diabase. It is bordered on the north by shale and sandstone containing indeterminate fossils suggestive of the Eocene, and on the southeast by shale and soft sandstone in which only unrecognizable plant fragments were seen. On the southeast side the shale, where exposed, dips more than $40^{\circ}$ $\mathrm{SE}$., probably a local effect of the igneous intrusion. The general structure is unknown.

Near Alsea post office, in the western part of the county, the canyon of Alsea River opens out into a wide valley, in which thoroughly rotten shale or clay is exposed at a few localities along the wagon road. No fossils were found except a spiral cast, like Turritella, but it is probable that the shale is Eocene, for it lies between two areas of Eocene sandstone, mostly marine on the east and mostly massive fresh-water sandstone on the west, which, in general, dips away from the shale area. This suggests an anticline, but farther north many opposing dips are due to tilted fault blocks or to faulted anticlines which are too broken to be placed in the category of ordinary folds. The entrance to the narrower valley or canyon below Alsea is basalt, and basalt composes the hills north of Alsea. Westward down the Alsea Canyon little is seen but massive Eocene sandstone, practiaally barren of fossils. That much of this sandstone is probably of fresh-water origin is suggested by the structure and general appearance and by the occurrence of thin partings of coal. It is probably equivalent to the Tyee sandstone, in which most of the canyons of Siuslaw and Umpqua rivers are cut.

According to Diller, ${ }^{1}$ shale and thin-bedded sandstone containing much volcanic material outcrop in Blodgett Valley, in the northwestern part of the county. They dip $40^{\circ} \mathrm{NW}$., and in a bluff north of the wagon road 50 feet of them are well exposed. Fossils collected half a mile northeast of Blodgett station were referred with doubt to the Oligocene by Dall.

\section{INDICATIONS OF OIL.}

No indications of oil or gas in Benton County have been reported. 


\section{IINCOLN COUNTY.}

\section{GEOLOGY.}

No work was done in Lincoln County in this reconnaissance, and available knowledge of it is limited to earlier explorations by J. S. Diller and by the writer, neither of whom has been in the northern part of the county.

Cape Foulweather is a characteristic basaltic headland of the Oregon coast, flanked on both sides by sand beaches, back of which are cliffs of marine Miocene sandstone and shale. The strata of the low cliffs between Otter Rock and Yaquina Bay have been described by Diller. ${ }^{1}$ At Otter Rock the thin-bedded yellowish sandstone dips about $18^{\circ} \mathrm{SW}$. and strikes N. $8^{\circ}-13^{\circ} \mathrm{W}$. At the southern end of the rock the light-colored Miocene beds are greatly fractured and show an abrupt change in the character of the material that suggests a fault, which, however, according to Diller, may not displace a great thickness of strata. The Miocene strata continue along the beach as far south as Newport, all dipping toward the sea and all representing horizons high in the Miocene.

South of Newport exposures of marine rocks are few, except at the mouth of Yahats River at the southern end of the county, where coarse upper Miocene sandstone and fine conglomerate dip $10^{\circ}-20^{\circ}$ W. These are succeeded on the south by the large mass of igneous rock which makes Cape Perpetua, on the Lane County line. East of the Miocene beds at Yahats exposures are few, except in the narrow valley of Alsea River, which is cut in massive, gently inclined sandstone that continues up the river beyond the Benton County line. No fossils have been found in this sandstone, but it is thought to be the same as the big sandstone on Siuslaw River, which the writer has practically connected in outcrop with the Tyee sandstone (Eocene) of Douglas County. Thin coal beds of no proved value have been found in the upper part of the sandstone on the lower Alsea.

On Yaquina Bay marine Miocene strata underlie the strata exposed at Newport. On the east side of the bay the strata are largely sandy shale, and at Rocky Point, 4 miles east of Yaquina, Diller $^{2}$ obtained Miocene fossils from the underlying dark clay shale. Near the latter locality are outcrops of massive yellow sandstone, similar to that which may be seen in places on Elk Creek for about 15 miles eastward, the relations of which are unknown. The writer has regarded it as Eocene, but no certain Eocene fossils have been found in it nor in any other rocks on the west side of the summit of the Coast Range between Siuslaw and Tillamook rivers. 
At Pioneer is one of the best known quarries of building stone in Oregon. The rock, which is light gray, homogeneous, and nedium grained, occurs in beds 5 to 10 feet thick, which dip about $20^{\circ} \mathrm{N}$. This rock is different in texture and general appearance from the apparently underlying sandstone on Elk Creek and from all other sandstones seen in the region. Its age is unknown.

Considerable prospecting for coal has been done north of Yaquina River about 6 miles from the coast in strata of Miocene or Oligocene age which underlie the strata exposed at Yaquina and Newport. According to Diller ${ }^{1}$ the coal beds are from 20 to 36 inches in thickness and the coal is inferior in quality.

\section{INDICATIONS OF OIL,}

No indications of oil or gas have been found in Lincoln County, the nearest known indication being on the north fork of Siuslaw River, 20 miles south of the southern boundary of the county. Large areas in the southern part of the county are almost free from igneous dikes and have low dips of $5^{\circ}-20^{\circ}$. The region has not been examined sufficiently to permit the location of folds which, if present, must be very gentle. The structure of the southern part of the county does not seem to be unfavorable to the occurrence of oil.

\section{LANE COUNTY.}

This reconnaissance did not extend to Lane County, and the following description is written largely from memory of earlier work, when the writer was a student under Prof. Thomas Condon, of the University of Oregon.

GEOLOGY.

GENERAL FEATURES.

The eastern half of Lane County lies in the Cascade Mountains, which in Oregon are composed almost wholly of igneous rocks. Oil therefore is not to be expected in that region. The central part of the county is occupied by the comparatively narrow Willamette Valley, which consists of alluvial plains from 10 to 20 miles wide. West of the valley is the Coast Range, mostly low dissected hills of sandstone with numerous higher ridges of volcanic rock. The low open folds of the latter region and the presence of oil indications near the coast make it the most likely part of the county to become productive of oil.

WESTERN LANE COUNTY.

Along the coast there are no exposures of the bedrock except in the northern part near Heceta Head and Cape Perpctua, which are prominent headlands of basalt. At the former there is much basaltic 
tuff and agglomerate, between the fragments of which a few Miocene echinoderms and sea shells have been found. The tuff dips about $15^{\circ} \mathrm{W}$. On the north side of Cape Perpetua, at the mouth of Yahats River, is an outcrop of Miocene sandstone. (See p. 95.)

Back from the coast line the first rocks encountered are fresh-water (?) sandstone and shale, very poorly exposed and dipping westward at low angles. A few miles from Heceta Head and at Acme coal beds too thin to mine have been found in these rocks. The sandstones are mostly thin bedded and do not outcrop conspicuously. They are succeeded on the east by massive yellow sandstone, which makes high cliffs in the steep-sided valley of Siuslaw River between Mapleton and Deadwood, where it is slightly folded or warped into low anticlines and synclines with dips of about $5^{\circ}$. The sandstone is composed of medium-sized angular grains, mostly quartz, with much opaque white soft material, which may be feldspar, and considerable white mica. It is ripple marked in places and is locally cross-bedded. At one place, where the stage road cuts under a high overhanging rock, many slickensided blocks of the sandstone are exposed, but no other evidence of faulting was seen. The sandstone possibly extends down the river to Point Terrace, where there is a quarry in similar material. A formation of the same appearance was found on the headwaters of Smith River in Douglas County, apparently continuous on the south with the Tyee sandstone of the Roseburg region.' The sandstone above Mapleton is more than 1,000 feet thick and contains very little shale. The base is not exposed, and the top is indeterminate owing to absence of exposures on the east. Igneous rock is comparatively scarce in this part of the county, only a few big basalt dikes, such as the one which makes the high point at Mapleton, being seén.

Between the mouth of Lake Creek and Triangle Lake is hard thinbedded sandstone, which, immediately below Triangle Lake, is cut by a few basalt dikes. At the falls, in the outlet of the lake, the sandstone is well exposed, dipping $20^{\circ}-30^{\circ} \mathrm{SW}$. Farther down Lake Creek, near Greenleaf, the sandstone ledges make riffles that trend northwestward. The age of these rocks is unknown.

Miocene fossils were obtained from a small quarry beside the wagon road a mile east of Blachly post office and about 2 miles northeast of Triangle Lake. These are the only fossils found on Lake Creek. Northwest from Blachly to Prairie Mountain, at the head of Lake Creek, the sedimentary rock is mostly dark shale, with hard thin-bedded sandstone poorly exposed. Prairie Mountain is a large sill or small laccolith of diabase, intruded in the shale. Its high, nearly level crest line is a conspicuous feature of the region.

1 Diller, J. S., U. S. Geol. Survey Geol. Atlas, Roseburg folio (No. 49), 1898. $47196^{\circ}-$ Bull. $590-14-7$ 
In the south, between Mound and Mapleton, Siuslaw River flows in a canyon of increasing depth and steepness, cut mainly in massive sandstone. Above Mound the valley opens out and the few exposures of rock are mostly sandy yellow shale.

WILLAMETTE VALLEY.

Near Lorane and eastward toward Cottage Grove there are some fairly good outcrops of sandy concretionary shale and soft sandstone dipping eastward at a very low angle. No recognizable fossils were found here, and the age of the shale is doubtful. A few poor casts, suggestive of Miocene forms, were found at Lorane, where a more thorough examination is recommended. Overlying this shale, west and north of Cottage Grove, is a thick body of tuffaceous sandstone and soft andesitic agglomerate, much of which is deeply decomposed into red and yellow clay. This is capped near Cottage Grove by thin flows of basalt.

Along the eastern foot of the Coast Range and in hills that rise from the alluvium of the Willamette Valley there are scattered outcrops of tuffaceous Miocene sandstone and shale. These occur on Ferguson Creek and eastward in the cemetery hill about 5 miles west of Junction City; where they dip eastward at low angles and are cut by dikes of igneous rock.

Eocene fossils were found at Richardson Butte, near Franklin, but farther south no fossils have been found except at Hadleyville, where Oligocene (?) forms were found in sandy shale. About 5 miles east of Hadleyville, at the coal prospect on the Owen farm on Spencer Creek, Miocene rocks reappear with abundant but poorly preserved fossils. The beds dip at a low angle southeastward and are thought to lie below the fossiliferous strata near Eugene and Springfield, with which, however, they have many species in common. Basalt dikes are comparatively scarce in this part of the country, as well as along Siuslaw River, where many entire townships do not contain more than one or two dikes. This is in marked contrast to the northern part of the Coast Range and to the eastern side of the Willamette Valley, where dikes are very numerous, numbering 10 to 20 in a single township. In T. 18 S., R. 3 W., immediately south of Eugene and Springfield, the dikes number several hundred, and detailed work such as has been done in that township would probably reveal a similar condition in other places, especially along the east side of the Willamette Valley.

The hills that lie just south of Eugene and extend eastward to Springfield are composed of sedimentary rocks of the upper division of the Miocene. (See p. 25.) The dips are prevailingly $5^{\circ}-15^{\circ} \mathrm{E}$., rarely $20^{\circ} \mathrm{E}$., but there are a few local variations and reversals of the dip due to the very numerous igneous dikes. Spencer Butte, a com- 
manding hill of more coarsely crystalline and more feldspathic rock (fine diorite ?), rises near the center of the dikè-ribbed district, and many of the dikes are approximately radial to it. The butte is a remnant of an old volcano, of which only one surface lava stream remains in the flow that makes the summit of the highest ridge immediately west of the butte. Many sills of basalt, mostly olivine basalt, which were intruded between the Miocene strata, are characterized by columnar joints of remarkable perfection and great size. Some of the columns near the center of the sill composing Skinner Butte, on the north side of Eugene, are over 3 feet in diameter. This sill is over 250 feet thick and dips about $5^{\circ} \mathrm{E}$. in general conformity with the stratification. Feeding dikes to the main mass are exposed in the sewer trenches and wells on the lower slopes of the butte. Its thickness in relation to its apparently small lateral extent, as indicated by change in texture and in size of columns, would probably justify one in calling it a small laccolith.

The sedimentary rock in which these igneous bodies are intruded is largely sandy shale, with many thick beds of soft bluish sandstone, weathering yellow, much of which is tuffaceous. A coarse conglomerate on Hemenway Butte, 9 miles west of Eugene, is probably at the base of the Miocene series, for a shale poorly exposed near Elmira, 4 miles farther west, resembles the Eocene shale near Franklin, 6 miles farther north, with which it appeais to be continuous. Thinner beds of conglomerate occur at several higher horizons at College Hill and near Springfield. Andesite and dacite compose the majority of the pebbles in the conglomerates. Sandy shale is probably the most abundant rock in the Miocene series, but the argillaceous and tuffaceous sandstones are most conspicuous. Marine fossils are numerous and are locally well preserved, especially in the concretionary masses of calcareous sandstone on the west side of College Hill. A list of fossils from the upper division of the Miocene, collected between College Hill and Springfield, is given on page 25.

The marine Miocene has not been recognized with certainty south of Goshen. It outcrops in places between the latter place and Springfield, dipping $5^{\circ}-20^{\circ} \mathrm{E}$. or SE., and is cut by a multitude of dikes. Six miles north of Springfield it reappears along the base of the Coburg Hills, which it skirts across the Linn County line to Twin Buttes south of Brownsville. The Miocene marine rocks at the base of the Coburg Hills all dip eastward, as though passing below the fresh-water strata composing the hills. The latter, however, appear from the fossil flora found in them and in similar rocks near Goshen to be older than the marine strata. The Coburg Hills are therefore regarded as an uplifted fault block.

The fresh-water rocks of the Coburg Hills and near Goshen are highly tuffaceous light-colored sandstone and shale, with a few thin 
coal beds. A little dark clay shale on the Murch homestead east of Coburg, and also near the coal prospects east of Creswell, is thought to belong to the same formation. Beautifully preserved fossil leaves and even delicate insects occur in the fine tuffaceous mudstone north of Goshen. A collection of the leaves was referred to Knowlton, who pronounced them Oligocene or possibly lower Miocene.

The fresh-water rocks just described are of unknown thickness, as their base is not exposed; apparently not over 500 feet is present at any locality. Painstaking detailed work will be required to determine the thickness of any of the formations of Willamette Valley. They are overlain in the upper part of the Coburg Hills by lavas and agglomerates, largely andesitic, which compose the east slope of the Coburg Hills to Mohawk River and eastward into the Cascade Mountains.

\section{INDICATIONS OF OIL.}

No anticlines or other structures suitable for the accumulation of oil have been found in Lane County east of the summit of the Coast Range, but along Siuslaw River, between Mapleton and Mound, a number of small low folds with very gentle dips seem to offer favorable conditions for such accumulation. This district has the further advantage of being comparatively free from basalt dikes, which are regarded generally as elements of weakness in a structure that might otherwise hold oil. In the oil fields of the Mexican Gulf Coastal Plain there are many basalt dikes, along which the oil escapes to the surface, but the oil in such broken fields is very heavy and viscous.

The only liquid oil which the writer has been able to find in the rocks of any part of western Oregon occurs in cavities in basalt in the western part of Lane County. The locality is on the ranch of A. B. Johnson, on North Fork of Siuslaw River, about 6 miles northeast of Florence. The oil is found mainly in cavities, rarely in very narrow joints, near the lower margin of an inclined dike or sill in Eocene (?) sandstone and shale that are not well exposed. A sample was examined in the laboratory of the Geological Survey by D. T. Day, who reports as follows:

Examination of the basalt shows that it contains -two kinds of hydrocarbonsone oily and soluble in gasoline, the other a typical asphalt insoluble in gasoline but soluble in both ether and benzol. The sample contains about 0.4 per cent of the latter and about 0.1 per cent of the former.

When the locality was examined by the writer in 1901, it was observed that the two types of hydrocarbon mentioned by Day were very distinct in character and bore evidence of having entered the rock cavities in two different periods, separated by an interval of rock weathering. No gradation between the solid and the liquid hydrocarbons was observed. The former is dense, black, solid but not brittle, probably less elastic than paving asphalt, and breaks 
in irregular curved fractures. It readily melted when placed on a stove, and it could be lighted and would burn with a smoky yellow flame. The liquid phase is yellowish brown, viscous, almost transparent in small drops, and undoubtedly reached its present resting place in the basalt cavities some time after the infiltration of the oil from which the solid black residue was deposited. The solid residue coats the cavities in the basalt to a thickness of 1 to 4 millimeters and in places fills them completely. Within the shell of black asphalt there is commonly a layer of calcite and zeolite, which was evidently deposited upon the asphalt that must have formed the solid wall of the cavity at the time of the formation of the shell of white minerals. In some specimens the white minerals completely fill the central cavity; in others partial crystal faces and zeolite needles project into the interior of the cavity. These white minerals probably grew in an aqueous solution, which had leached carbonates and hydrous silicates from the basalt within the zone of rock decay not far from the surface. After the deposition of the zeolite and calcite liquid oil in some way managed to penetrate the coatings of asphaltum and white minerals and to reach the center of the cavities, where it now fills the space previously occupied by water. In a few specimens unbroken zeolite needles were observed protruding into a cavity almost completely filled with oil. Oil also occurs in the joints of the basalt. The liquid oil is evidently a comparatively recent infiltration, accomplished after erosion had removed enough of the overlying material to bring the rock represented by the samples close enough to the surface to be within reach of meteoric waters charged with the dissolved products of rock decay. The infiltration of the first oil, from which the solid black asphaltum has been derived by the loss of its liquid solvents, took place before the deposition of calcite or zeolite in the rock cavities; but whether this event accompanied the basaltic intrusion or succeeded it. after a long period of time can not be determined. The latter alternative is supported by the apparent distribution of the asphalt, which has been found only near the lower margin of the basalt, suggesting that the oil has entered the rock from the underlying sedimentary rocks.

The liquid oil in this basalt is free migratory oil and as such is the best kind of an oil indication, but its quantity is small. No oil was observed escaping to the surface at springs in this region; that is, there are no true oil seeps, and none are known to the writer in any part of western Oregon.

A black pigment, probably hydrocarbon, was -found many years ago in the cleavages of calcite crystals in a little veinlet cutting a basalt dike on the Southern Pacific Co.'s line a mile east of Sp:ingfield Junction. No solubility tests were made on this material, but it disappeared when strongly heated. 
Many other supposed indications of oil and gas have been examined at different times, but in every case it was determined that other substances, mostly iron scums, had deceived the finder.

One report which is probably worthy of examination was received in a recent letter from George Pirie, of Creswell, who writes that the water in his well shoots into the air often 20 feet when it is first pumped. After this happens no water can be obtained for a minute or more. This behavior suggests gas in the water. The well is 380 feet deep, having been drilled through a "soft black rock that turns white in the air." It is located in sec: 33 , T. 18 S., R. 3 W., about $3 \frac{1}{2}$ miles northwest of Creswell.

S. J. Renne, of Creswell, writes that he has found a spring, about 4 miles south of that town, in which he believes there are traces of oil. He observed "reddish-looking globules about the size of a match head start from the bottom and slowly rise to the top, where they burst and spread out on the surface of the water." From Mr. Renne's description it seems possible that he may have found a true oil spring.

\section{DOUGLAS COUNTY.}

GEOLOGY.

The eastern part of Douglas County is composed of the igneous rocks of the Cascade Mountains, and the southern part is underlain by Cretaceous and pre-Cretaceous rocks, all, especially the preCretaceous, being more or less metamorphosed. Tertiary sedimentary rocks, mostly Eocene, occupy the northwestern part of the county, and there seems to be little chance of getting oil outside of the area covered by them. Much of the valley of Umpqua River between Roseburg and Coles Valley is occupied by the Umpqua formation (Eocene). Below Coles Valley the river flows through a narrow valley cut in the massive Tyee sandstone, overlying the Umpqua formation. Eocene sandstone also composes most of the higher part of the Coast Range in the western part of the county. For the details of the distribution and structure of these formations the reader is referred to Diller. ${ }^{1}$

\section{INDICATIONS OF OIL.}

Douglas County is not embraced in the area examined in this reconnaissance and the value of the following reports is unknown. They are given here for the use of those who may desire to investigate them.

A well was being drilled in 1910 by F. W. Dillard and others about $7 \frac{1}{2}$ miles west of Roseburg, in sec. 36 , T. 27 S., R. 7 W. In July,

1 U. S. Geol. Survey Geol. Atlas, Roseburg folio (No. 49), 1898; A geological reconnaissance in northwestern Oregon: U. S. Geol. Survey Seventeenth Ann. Rept., pt. 1, pp. 447-520, 1896; The Mesozoic sediments of southwestern Oregon: Am. Jour. Sci., 4th ser., vol. 23, pp. 401-421, 1907. 
$1910, \mathrm{Mr}$. Dillard wrote that his well was 700 feet deep, all in shale (Umpqua formation), and that he was finding some oil in the shale.

In Lookingglass Valley, in the western part of the county, indications of oil are reported by T. L. Lee and S. R. Brisbin, of Lookingglass. Mr. Lee writes that in a well drilled on his farm in 1909 to a depth of 110 feet a trace of oil was encountered at 70 feet. A scum which appeared on the surface of the water is said to have been collected and to have been tested and proved to be crude oil. This locality is about a mile from Mr. Dillard's well, mentioned above.

Mr. W. A. Invrie, of Melrose, writes that he has a well 75 feet deep, which furnishes a strong flow of white sulphur water that contains gas.

\section{COOS COUNTY.}

GEOLOGY.

All but the southern end of Coos County is underlain by Tertiary rocks, mostly Eocene, with a subordinate amount of intrusive igneous rock. The strata are folded, especially in the western part of the county, where there is at least one anticline of form suitable for the accumulation of oil. This structure, which Diller has named the Westport arch, and the detailed-distribution of formations have been described by Diller. ${ }^{1}$

\section{INDICATIONS OF OIL AND GAS.}

- In the Newport and Libbey mines of the Coos Bay coal field Diller found veins of "pitch coal" cutting the strata. This substance is regarded ${ }^{2}$ as an oil residue, left after the passage of oil through the fissures. It is very old and jet-black, and the last movement of oil depositing it must have taken place long ago-probably in the first half of the Tertiary period. Its age is shown by its brittleness and density and especially by its abundant joints, which indicate that it has been subjected to shearing stresses that did not affect the Miocene lignitic coals farther north. The late Tertiary strata of western Oregon are so slightly deformed, so loosely consolidated, and so nearly free from joints that the writer is inclined to place the age of this oil residue in the early Tertiary, at least as far back as Miocene time and probably further. The veins of "pitch coal" cut across beds of subbituminous coal and sandstone of Eocene age. The antiquity of this substance weakens its value as an indication of existing oil. No fresher hydrocarbon, either solid or liquid, has been reported from the fissures.

1 U.S. Geol. Survey Geol. Atlas, Coos Bay folio (No. 73), 1901; idem, Port Orford folio (No. 89), 1903; The Coos Bay coal field, Oreg.: U. S. Geol. Survey Nineteenth Ann. Rept., pt. 3, pp. 309-376, 1899.

2 Day, W. C., The coal and pitch coal of the Newport mine: U. S. Geol. Survey Nineteenth Ann. Rept., pt. 3, pp. 370-376, 1899 . 
W. S. Chandler, of Marshfield, writes that he found traces of oil in a diamond drill hole 600 feet deep which he made on the George Vernon property, on the Westport arch, a few miles south of the Libbey mine. Mr. Chandler writes:

The oil saved from the hydraulic overflow was mixed with the fine borings of the drill and was merely sufficient to fill an ordinary tomato can, which was sealed and forwarded to San Francisco to be analyzed: The result of the chemist's analysis proved a paraffine base, but the chemist stated that the quantity received, owing to its dirty condition, was too small to make a proper test. There was no gas noticeable at any tinne during the process of drilling and no further indications of oil after passing a depth of 450 feet or thereabouts. The hole was drilled with a diamond drill, giving a core $1 \frac{7}{8}$ inches in diameter.

It is reported by his daughter that the late H. M. Butler, of Empire, found oil seeps on his farm in secs. 26 and 27, T. 26 S., R. $14 \mathrm{~W}$., from which he collected the oil on a rag and afterward burned it.

Farther south, near Harbor, at the southern end of Curry County, there is said to be "a flow of natural gas on the coast, also on the table-land about one-half mile from the first."

The Miocene Oil \& Gas Co. has been organized at Bandon, Coos County, for the purpose of drilling in sec. 12, T. 28 S., R. 14 W., near Bear Creek.

Several additional "seeps" bave been reported from Coos County, but the descriptions indicate that the supposed oil is only iron scum, which is frequently mistaken for oil. All the samples submitted to the writer for examination were of the latter substance. The writer places confidence in the report of oil encountered in the diamond drill hole, sunk in prospecting for coal south of the Libbey mine, because of the technical ability and integrity of the informant. Many geologists would doubtless find much significance in the large veins of "pitch coal," which is an ancient oil residue.

In spite of the paucity of surface indications the writer is inclined to recommend the drilling of a test well on the Westport arch by those who can afford to take a "long chance." The stratigraphy and structure of the southern end of the arch are favorable, but it must be borne in mind that this is not a prediction that oil will be found at that place. It will require a test well to determine whether or not the rocks are oil bearing, and the Westport arch is recommended only because it seems to be the best place structurally to make the test. The location of the arch is shown on the geologic map in the Coos Bay folio (No. 73) of the United States Geological Survey. 


\section{CONCLÚSIONS.}

In the opinion of the writer there is no good reason for believing that oil will be found in the northern part of the Coast Range of Oregon. Farther south in Lincoln, Lane, and Coos counties it may be looked for with greater promise of success. As others will doubtless disagree with these views, the main arguments on which they are based are stated below. The reader is cautioned to bear in mind that in the present state of oil science, it is impossible to make an absolute decision as to the presence or absence of commercial quantities of oil in unexploited regions.

\section{EFFECT OF STRUCTURE.}

The structures observed in western Lane and Lincoln counties, namely, broad low folds with only a few widely separated dikes of igneous rock, are suitable for the concentration and retention of oil. Farther north the folds are similar and might favor the formation of oil reservoirs if in that region they were not cut by many large masses of igneous rock and by a multitude of small dikes and faults. Large intrusive masses, several miles across, occur in western Benton County, and in western Yamhill, eastern and northern Tillamook, and southern Clatsop counties. Innumerable dikes cut the rocks of all the northern counties in the Coast Range. The large anticline at Fort Columbia and Astoria is cut by a parallel fault of sufficient magnitude to remove most of the Eocene from its west limb and by dikes.

Although experience in the Mexican and other oil fields shows that dikes and faults are not necessarily destructive of oil reservoirs, nevertheless they must be considered elements of weakness, as they tend to promote the escape of oil to the surface. If the underlying strata still contain oil, seeps should occur along some of the dikes or faults, but, as stated above, no true oil seeps have yet been found in western Oregon.

In regions of heavy rainfall, such as western Oregon, the porous rocks are undoubtedly saturated with water, as confirmed by all the deep wells. Prospectors, therefore, should first look for oil in the upper parts of anticlines.

\section{EFFECT OF STRATIGRAPHY.}

The stratigraphic details of the formations of the Coast Range are too little understood to warrant more than tentative inferences. In a broad way the strata, which range from upper Eocene to upper Miocene, are of the same age as the oil formations of California. But in California Arnold has found reason for believing that the oil is of diatomaceous origin, and there are few if any remains of diatoms in the Tertiary formations of western Oregon. It is not improbable that the numerous flinty concretions in the Astoria shale are aggregations 
of silica derived from the skeletons of minute organisms, possibly diatoms, but no skeletons are revealed by the microscope in any of the samples examined. Near the middle of the Astoria shale several layers of shale 1 foot to 10 feet thick contain the shells of small rhizopods and foraminifers, from 1 millimeter to 5 millimeters in maximum diameter and composing probably less than 5 per cent of the mass of any layer. The total volume of organic matter indicated by these shells and by all other visible remains in any formation of western Oregon does not seem to be sufficient to have produced great quantities of oil by processes of natural distillation or decomposition. Certainly the volume of organic remains is insignificant in comparison with that in the thick diatomaceous formations of southern California.

The preceding argument is weak, as it is based on a theory of origin, but it is in accord with the prevailing views of other geologists. The writer prefers to discount it, because of the possibility, by no means remote, that oil is of volcanic origin.

The stratigraphy of northwestern Oregon is favorable to the creation of oil reservoirs, for many of the sandstones are sufficiently porous to contain oil and the overlying shales are sufficiently impermeable to keep it from escaping. In the region occupied by the Tyee sandstone, between the Umpqua and the Yaquina rivers, a traveler gains the impression that there is practically no shale present. However, there are a few exposures of shale, and there is physiographic reason for believing that several beds of shale, nearly 100 feet thick, occur in the formation. Likewise in the Astoria shale there are beds of sandstone, especially near the top and bottom, which are sufficiently porous to hold oil. In nearly all the other formations, especially in the upper Miocene of the Willamette Valley, there is a favorable alternation of shale and sandstone.

The feature of the stratigraphy which is least favorable to the accumulation of oil is the presence in many places of lava flows and intrusive sheets. A large part of Columbia and Washington counties and nearly all of Multnomah and Clackamas counties are covered with basalt, which makes drilling exceedingly difficult and which is probably thick enough in most places to destroy any reasonable probability of getting oil. The diabase tuff and agglomerate and the thin lava flows in the Eocene probably make it impossible to drill below the Astoria shale in the region of the lower Columbia River.

\section{SIGNIFICANCE OF INDICATIONS OF OIL.}

By far the most important evidence in regard to the oil-bearing character of unexploited formations consists of traces or residues of oil. Although it is probable that there are indications which were not seen in this reconnaissance, nevertheless sufficient work has been done to show that indications are very scarce. Up to the present time there has been no authentic discovery of a true "oil seep," a place where liquid oil is escaping at the surface. 
The rocks still hold small amounts of liquid oil at several localities: (1) In porous basalt on the Johnson ranch, on the North Fork of Siuslaw River, western Lane County; (2) in concretions of limestone in shale, at Hawkins Ranch, on Bear River, Wash.; (3) in similar concretions at Cementville, on the north bank of Columbia River opposite Astoria; and (4) in concretions from sekeral localities in Astoria. At the first locality the oil is in large viscous brown globules; at the other localities it is invisible, being diffused in the rock, and can be obtained only by distillation or by extraction with ether or chloroform. All of these occurrences are in very dense rocks, such as might be expected to protect the oil from evaporation and from circulating water. No liquid oil has been found in sandstone or shale in the area examined, but it is reported that there is an outcrop of oil-charged sand farther north on the west side of Olympic Mountains of Washington.

In western Oregon oil residues are much more abundant than traces of liquid oil. The residues are black veinlets of solid hydrocarbons in many different kinds of rock and globules of the same material filling pores in basalt. Such residues indicate the former presence and circulation of oil. They do not indicate necessarily that oil still remains in the rock. On the contrary, such recurrences as the "pitch coal" of Coos Bay, which was highly jointed and sheared in pre-Miocene time, indicate that there has been no recent movement of oil and suggest that the original supply in that locality was exhausted in the Tertiary period. If oil had been circulating through the fissures since the period of deformation, it would have left residues free from joints and cleavage planes.

The solid hydrocarbons found north of Coos Bay are of the latter unjointed type. All of the solid residues which the writer has seen were brittle and broke with conchoidal fracture, but Collier (see p. 67) reports one locality in eastern Tillamook County where he found a natural hydrocarbon with the consistency of wax. Solid black brittle hydrocarbons are associated with the oil at localities 1 and 2 as noted above. One minute veinlet was observed in the shale in Astoria; and a black hydrocarbon answering the solubility tests for grahamite was found in the steam blebs of several basalt dikes near Astoria on both sides of Columbia River and in a dike on the Northern Pacific Railway east of South Bend, Wash.

As an indication of petroleum, traces of gas are even more uncertain than dry residues, because it is generally impossible to tell whether the gas is associated with oil or is marsh gas, such as commonly forms in sediments containing decomposing vegetation. Gas is escaping from the beds of nearly all the tidewater creeks and sloughs and from many fresh-water lakes, locally in appreciable quantity, but it is probable that all of these occurrences are only gas which has formed in the superficial sediments and which is not connected with deep-seated reservoirs. 
The gas found in the deeper wells, such as the well near Dallas (see p. 89) and the Harrison well on Youngs River (p. 58), undoubtedly comes out of the Tertiary rocks. The gas which makes the mud volcano near the mouth of Hoh River, Wash.; reported by Mr. Gayley, is also probably from the deeper formations. These occurrences give some encouragement to the prospector for gas fields, but their connection with oil is problematic.

Finally, the indications of oil are scanty and are not very satisfactory. ${ }^{1}$ The fractured condition of the strata, especially in the northern part of the Oregon Coast Range, would lead one to expect abundant indications of oil, if the fluid were present in large quantities. The geology of this region bears some resemblance to that of the coastal oil belt of Mexico, especially in the age of the strata, in the abundance of intrusive dikes and probably of faults, and in the low dip of the strata. The Mexican fields, however, contain hundreds of active and extinct oil seeps, most of them covering several square yards in area, and some spread asphalt over several acres. The oil seeps of southern California, although much less extensive than those of Mexico, are nevertheless of considerable magnitude. The basalt dikes and faults of northwestern. Oregon offer many more vertical passages for the escape of oil than are found in California, yet the oil indications of the former State are insignificant when compared with those of the latter. It is true that many good oil fields have been developed where no surface indications exist, but so far as known such fields are not cut by many vertical dikes. In a fractured region like northwestern Oregon it therefore seems reasonable to believe that the general absence of true seeps is an argument against the presence of much oil underground.

\section{ANALYSES OF GAS.}

Analyses of samples of gas from northwestern Oregon.

[Made at Pittsburgh laboratory of the Bureau of Mines; Geo. A. Burrell, chemist.]

\begin{tabular}{|c|c|c|c|c|c|c|c|c|}
\hline i. & 1060 & 1061 & 1063 & 1062 & 1064 & 1065 & 1067 & 1066 \\
\hline \multirow[t]{2}{*}{ 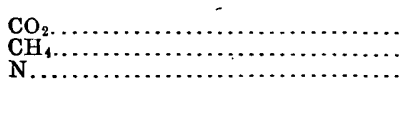 } & $\begin{array}{r}3.3 \\
95.7 \\
1.0\end{array}$ & $\begin{array}{r}3.5 \\
95.5 \\
1.0\end{array}$ & $\begin{array}{r}3.0 \\
96.1 \\
.9\end{array}$ & $\begin{array}{r}1.0 \\
91.0 \\
8.0\end{array}$ & $\begin{array}{r}1.2 \\
91.2 \\
\text { T. } 6\end{array}$ & $\begin{array}{r}0.5 \\
87.0 \\
12.5\end{array}$ & $\begin{array}{r}0.7 \\
86.2 \\
13.1\end{array}$ & $\begin{array}{r}0.15 \\
97.85 \\
2.00\end{array}$ \\
\hline & 100.0 & 100.0 & 100.0 & 100.0 & 100.0 & 100.0 & 100.0 & 100.00 \\
\hline
\end{tabular}

1060. From slough on Brown's dairy farm, in sec. 26, T. 8 N., R. 10 W., Clatsop County. Bubbles trapped by funnel bottle, water displacement. (See p. 57 .)

1061. Same as 1060.

1063. Same as 1060 . Obtained by air displacement from tank over pipe.

1062. From John Nelson's ranch in sec. 30, T. 10 N., R. 8 W., at Oneida, Wash. Obtained by air displacement. (See p. 58.)

1064. Same as 1062 . Water displacement.

1065. From Herrick's mineral spring at Grand Rapids on Nehalem River, in SE. $\frac{1}{4}$ sec. 23, T. 8 N., $R$.

7 W., Clatsop County. Air displacement. (See p. 59.)

1067. From bed of Nehalem River at Lukkarila ranch in SW. $\frac{1}{3}$ sec. 7, T 4 N., R. 7 W., Clatsop County. Air displacement. (See p. 59.)

1066. From well $5 \frac{1}{2}$ miles southeast of Tillamook, in SE. 1 sec. 10, T. 2 S., R. 9 W., Tillamook County. Air displacement. (See p. 68.)

1 Maberry has published a partial chemical study of a sample of viscous asphaltic oil (specific gravity 0.9597 at $20^{\circ} \mathrm{C}$.) which he received "from Oregon." No details of the occurrence are given, and its locality is unknown to the writer. See Am. Acad. Sci. Proc., vol. 32, p. 189, 1897; Am. Chem. Jour., vol. 19, p. 374; Am. Philos. Soc. Proc., vol. 36, p. 126, 1897. 
A.

Alsea, formations near................... 94

Asphaltum, report of discovery of ........ 67-68

Astoria, fossils from............... 27-28,30, 32 geologic formations in and near ......... 37-40

H. C. Harrison's well near............. 58-59 possibility of oil in.................. 39,54

Astoria shale, nature and occurrence of ...... 15-20

Aturis zone, how named ................. 10

\section{B.}

Barlow, formations near.................. 79

Barrells, W. A., hydrocarbon found by ..... 54-55

Bay City, formations at and near.......... 62 63

Beaver, formations near................ 64-65

Benton County, geology of .............. 92-94

indications as to oil and gas in.......... 94

Blachly, formations near................. 97

Bridal Veil, formations near................ 78

Brisbin, S. R., oil reported by............. 103

Brown's dairy farm, gas supply on........ $\quad 57$

Bugby, formations at.................... 43

Burnside, formations at.................. 42

Burrell, George A., analyses by........... 108

Butler, H. M., oil seeps found by .......... 104

\section{C.}

Cannon Beach, formations on.............. 50-51

Cascade Mountains, oldest rocks of ......... 13

Chandler, W. S., cited.................... 104

Clackamas, formations near............... $79-80$

Clackamas County, geology of ............ 78-80 reports of oil in ...................... 80

Clatskanie, formations near .............. 74-75 fossils from....................... 29, 30

Clatsop County, geology of .............. 37-52 indications of gas in . . . . . . . . . . . . $55-60$ indications of oil in .................. 52-55

Clifton, formations at and near. . . . . . . . 42-43

Coal, in Columbia County............... 71 in Coos County..................... 103 in Lane County................... 97,98 in Marion County .................. 90 in Tillamook County ................. $\quad 60$ near North Yamhill................. 83

Coast Range, features of .............. 5-6 structure of......................... 7

Coburg, formations near............... 100

College Hill, formations near................ 99

Collier, G. H., asphaltum discovered by .... 67-68

Columbia County, geology of . ........... 69-75 possibility of oil in................... reports of oil in.
Columbia River region, geology of .......... Page.

Concretions in the Astoria shale........... 16-17

Coos County, geology of................ 103

indications of oil and gas in.......... 103,104

Corvallis, formations near............... 92

Cresswell, oil and gas indications near....... 102

Cretaceous rocks, absence of ............... 8

D.

Dairy Creek, West Fork of, formations on ... 76-77

Dall, W. H., acknowledgments to......... 27,37

Dallas, formations near................. $\quad 88$

gas near.......................... $\quad 89$

Day, D. T., cited....................... 100

Dillard, F, W., oil reported by . .......... 102-103

Diller, J. S., cited ......................... 76-77

Dikes, sandstone, cause and occurrence of ... 17-18

Dolph, formations at and near............ 85

Douglas County, geology of............... 102 reports of oil in ..................... 102-103

E.

Elsie, formations near.................. 48-49

hydrogen sulphide gas near............ 59

Empire, oil reported at.................. 104

Eocene series, formations of ............... 8-13

Eola, hydrocarbon from .................. 89

Eugene, formations near............... 98-99 fossils from.................... 33, 34, 36

F.

Fairdale, formations near............... 83

Falls City, formations at and near.......... 88

Fernhill, formations at................. $\quad 42$

Florence, oil near..................... 100-101

Follett, Mrs. Helen, wells of ......... 80-81, 86-87

Fort Stevens, $\log$ of well at.............. 52

Fossils, occurrence of .......... 27-36 and passim

Frank, formations near................ $\quad \mathbf{8 0}$

$\dot{\mathrm{G}}$.

Garibaldi, formations near . . . . . . . . . . 61-62

Gas, analyses of ....................... 108

as an indication of oil............. 107-108

indications of, in Clatsop County ....... 55-60

in Yamhill County ................... 87

Gas prospects, map showing............ $\quad 5$

Glad Tidings, formations near............. 79

Goshen, formations near................ $99-100$

Grand Rapids, formations near............ 48

gas at............................ 59-60

Granger, formations near................... 91,93

Greenleaf, formations near................. $\quad 97$

Greensand, occurrence of ................. 18-19 
H.

Harbor, gas reported at

Harrison, H. C., wells of.................. 58-59

Hawkins's ranch, oil on ................. 53-54

Hemenways Butte, conglomeratic Miocene strata on..................... 23

Hemlock, formations at.................. 64

Home, A. M., ranch of fossils from........ 23, 33 ranch of, ledge on ..................... 88-89

Home Oil \& Gas Co.'s well, $\log$ of ........... $\quad 79$

Hydrocarbons, occurrences of............. 54-55

\section{I.}

Ilwaco, Wash., measurement of marsh gas near..................... 56-57

Invrie, W. A., gas reported by........... 103

$$
\text { J. }
$$

Jewell, formations near.................. 46-48 possibility of oil near.

Johnson, A. B., ranch of oil on. $100-101$

Junction City, formations near . . .......... 98

K.

Knappa, formations near................ 42

Knappton, Wash., fussils from.............. 32 hydrocarbon found at. ................ 54-55

Knowlton; F. H., determinations of fossil plants by

L.

Ladd, W. S., well of........................ 78

Landslides in Astoria.................... 19

Lane Cuunty, geology of ................. 96-100 indications of oil in ................ 100-102

Laughlin, Clarence, wells of............... $\quad 82$

Lebanon, formations near................ 92

Lee, T. L. oil reported by ................ 103

Lincoln County, geology of ................. 95-96 indications of oil in .................... 96

Linn County, geology of .................. 91-92 reports of oil in ..................... 92

Lookingglass, oil reported near............ 103

Loraze, formations near................... 98

Lukkarila's ranch, gas on................ 49,59

M.

McCoy, formations near. . ................ 88-89

McXinnville, formations near.............. 83-84

Macready, George A., acknuwledgments to.. 5

Mapleton, formations near............... 97,98

Marion County, geology of............... 90 indications as to oil in ................ 90

Mars.l gas, distribution of . . ................ 56-58

Marshfeld, oil reported near............... 104

Mars'iland, formations near................ 74

Melrcse, gas reported at. ................. 103

Miocene series, fossils of.................. 25-26 nature and occurrence of.............. 20-27

Mist, fossils near......................... $72-73$

Monroe, formations near.................. 93

Multnomah County, gevlogy of............ 77-78 indications as to oil in ................. 78

N.

Necarney Hydrocarbon Oll Co., well of ..... 68-69

Nehalem, formations near................ 61 prospect wells near..................... $68-69$
Page.

Nehalem beeswax, nature and occurrence of.. 65-67 Nehalem River, fossils from.............. 31 gas from ........................... 49, 59

Nehalem River basin, geology of.. 46-49,60-63, 70-74

Nelson, John, marsh gas utilized by......... 58

Nestugga River basin, geology of . ......... 64-65

Newburg, formations near............... 80-81

Newport, formations near . . ................. . 95

North Yamhill, formations near............ 81-83

\section{0 .}

Oil, indications of, in Astoria.............. 39 indications of, in Clatsop County ....... 52-55 significance of . .................. 106-108

Oil prospects, map showing. ............... $\quad 5$

Oil reservoirs, effect of stratigraphy on..... 105-106 effect of structure on................... 105

Oligocene series, formations of ............ 13-20

Olney, formations near.................. 44-45

$\Gamma$.

Paleontologic data...................... 27-36

Paraffine sandstone, nature and occurrence of $\quad 67$

Peterson Butte, fossils from............... $\quad 91$

Philomath, formations near. .............. 93-94

Pioneer, building stone at.................. 96

Pittsburg, formations near................. 73-74

Pliocene series, occurrence of . . ................ 27

Polk County, geology of ................. $87-89$ indications of oil and gas in............. $89-90$

Portland, formations near............. 77-78

Portland Coal \& Development Co., prospect well of, approximate $\log$ of....... 68 drill hole of

R.

Railroads that cross the Coast Range....... 7 Rainier, rocks near...................... 69-70 Roads, character of...................... $6-7$ Rogers, Reese F., acknowledgments to..... 5 Roseburg, oil reported near............. 102-103

S.

St. Helen, rocks near.................. $69-70$

Salem, formations near .................. 90

Scotts Mills, formations near............... $\quad 79$ unconformity at...................... 26

Sheridan, formations near................. 84

Short Beach, formations on............... 51

Southern Pacific Co.'s well at li.orth Yambill.

Springbrook, formations near.............. 80

Springfield, formations near.............. 98-99

fossils from . ....................... 35,36

Springfield Junction.................... 101 fossils from......................... 34

Svenson, formations at..................

T.

Tertiary system, formations of............ 8-27

Tillamook, formations near.............. 63-64

Tillamook County, geslogy of............... 60-65 prospect wells in .................... 68-69 reports of oil in .....................65-69

Tillamook River basin, gesligy of ......... 63-64

Tungue Point, formations at and near...... 41-42

Tuff beneath Astoria shale, nature and occurrence of..................... 10-13

Tyee sandstone, nature and occurrence of .... 9-10 
U.

Page.
$\quad 8,9$

Umpqua formation, occurrence of.

$\mathrm{V}$.

Vegetation, density of.

Vernonia, formations near

Vesper, formations near.

$$
\text { W. }
$$

Walters, J. J., acknowledgments to

Warrenton, wells at.

Washington County, geology of.

indication of oil in

Westport, formations at and near.
Westport arch, indications of oil on.

Miocene outcrops near................ 24

possible fault in . ................... 14-15

structure of.......................

Willamina, formations near......., ..... 84-85

Wilson River basin, geology of . .........60-63

Y.

Yambill County, geology of . . . . . . . . . 80-87

reports of oil in ..................... 86-87

Yaquina, formations near............... 95

Youngs Bay, formations on............... 51-52

Youngs River basin, geology of.......... 44-46 ge.

(1)

